MARCELO MONTE MOR RANGEL

Interferência da eletroporação sobre a expressão de conexinas

São Paulo

2011 


\section{Interferência da eletroporação sobre a expressão de conexinas}

Tese apresentada ao programa de PósGraduação em Patologia Experimental e Comparada da Faculdade de Medicina Veterinária e Zootecnia da Universidade de São Paulo para obtenção do título de Doutor em Ciências.

Departamento:

Patologia

Área de Concentração:

Patologia Experimental e Comparada

Orientadora:

Profa Dra Maria Lucia Zaidan Dagli

São Paulo 
Autorizo a reproduçåo parcial ou total desta obra, para fins acadêmicos, desde que citada a fonte.

DADOS INTERNACIONAIS DE CATALOGAÇÃO-NA-PUBLICAÇÃO

(Biblioteca Virginle Buff o'Ápice da Faculdade de Medicina Veterinárila e Zootecnla da Universidade de SSo Paula)

\begin{tabular}{|c|c|}
\hline \multirow[t]{5}{*}{$\begin{array}{l}\text { T.2422 } \\
\text { FMNZ }\end{array}$} & $\begin{array}{l}\text { Rangel, Marcelo Monte Mor } \\
\text { Interferéncia da eletroporação sobre a expressäo de conexinas } \\
\text { / Marcelo Monte Mor Rangel. - } 2011 \text {. } \\
120 \text { f. : il. }\end{array}$ \\
\hline & $\begin{array}{l}\text { Tese (Doutorado) - Universidade de Säo Paulo. Faculdade de } \\
\text { Medicina Veterinária e Zootecnia. Departamento de Patologia, Săo } \\
\text { Paulo, 2011. }\end{array}$ \\
\hline & $\begin{array}{l}\text { Programa de Pós-Graduaçäo: Patologia Experimental e } \\
\text { Comparada. } \\
\text { Area de concentraçäo: Patologia Experimental e Comparada. }\end{array}$ \\
\hline & Orientador. Profa. Dra. Maria Lucia Zaidan Dagli. \\
\hline & $\begin{array}{l}\text { 1. Eletroporação. 2. Eletroquimioterapia. 3. Conexinas. } \\
\text { 4. Neoplasias. } 5 \text {. Melanoma. I. Título. }\end{array}$ \\
\hline
\end{tabular}




\section{CERTIFICADO}

Certificamos que o Projeto intitulado "Avaliação da eficiência tẹrapêutica da eletroquimioterapia em melanomas da linhagem B16/F10 transplantados em camundongos C57/black", protocolado sob o n $1375 / 2008$, utilizando 180 (cento e oitenta) camundongos, sob a responsabilidade do Profa. Dra. Maria Lúcia Zaidan Dagli, está de acordo com os princípios éticos de experimentação animal. da Comissão de Bioética da Faculdade de Međicina Veterinária e Zootecnia da Universidade de São Paulo e foi aprovado na reunião do dia 23 de abril de 2008.

We certify that the Research "Evaluation of electrochemotherapy in melanomas line B16/F10 transplanted in mice C57/black", tutlizing 180 (one hundred eight) mice, protocol number $1375 / 2008$, under the responsibility Profa. Dra. Maria Lacia Zaidan Dagli, agree with Ethical Principles in Animal Research adopted by Bioethic Commission of the School of Veterinary Medicine and Animal Science of University of Sảo Paulo and was approved in the meeting of day 04/23/08.

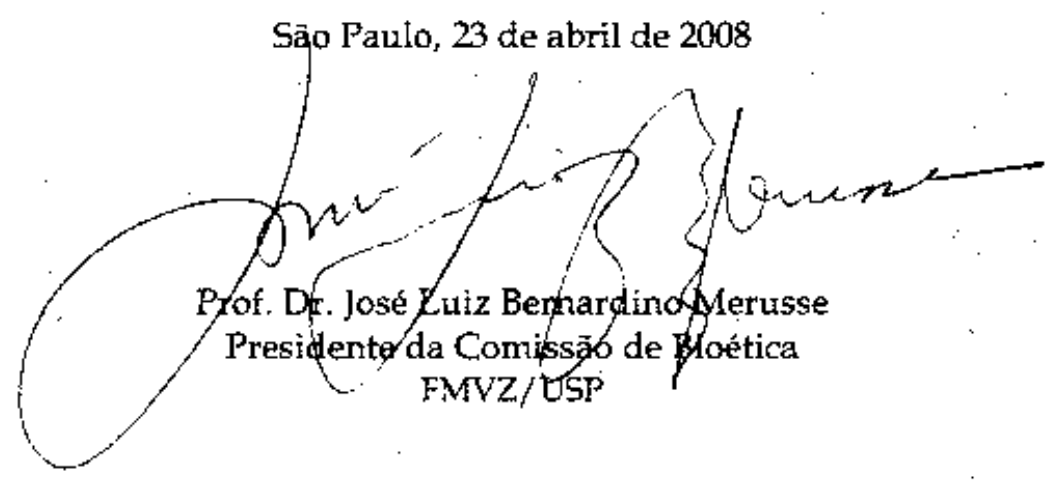

A. Prof. De Orianda Marques de Paika to Cidade linivtsidria "A otratdo de Salles Oleveita" Sü Panlo'SF - Brusil $05508-270$
FondFax: +55 I ] 3032-2224:3091-7757 - $55113091-76717676$

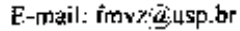

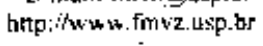




\section{FOLHA DE AVALIAÇÃO}

Nome: RANGEL, Marcelo Monte Mór

Título: Interferência da eletroporação sobre a expressão de conexinas

Tese apresentada ao Programa de PósGraduação em Patologia Experimental e Comparada da Faculdade de Medicina Veterinária e Zootecnia da Universidade de São Paulo para obtenção do título de Doutor em Ciências

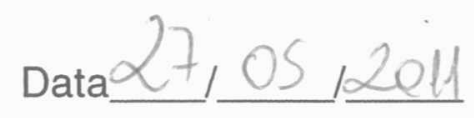

\section{Banca Examinadora}

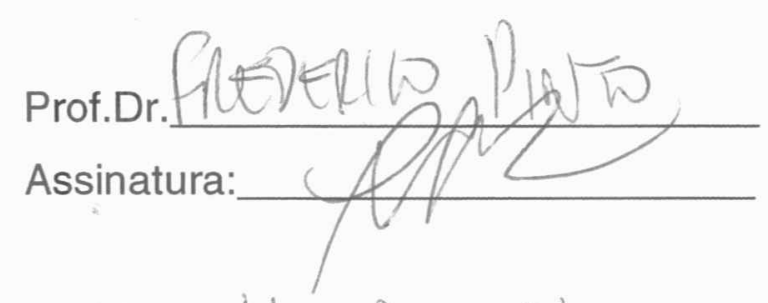

Prof.Dr. Lluis Maria nie Assinatura:
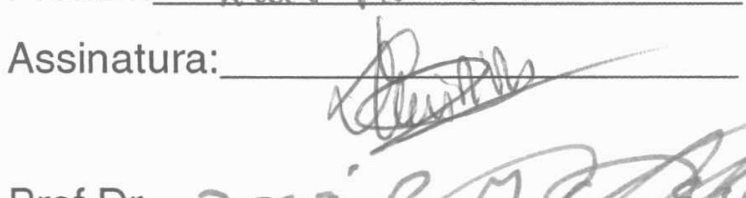

Prof.Dr. 20s' Assinatura:

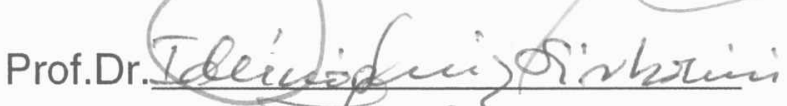
Assinatura: Mavia Wiatiz. Daghi

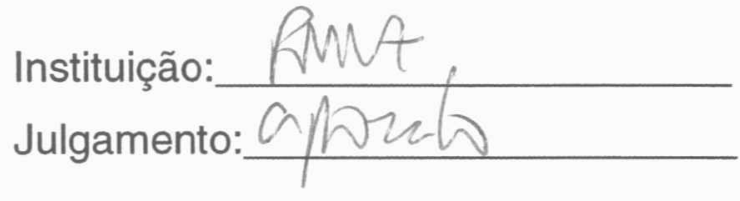
Instituição: Zustitul Gushave Rovisy Julgamento: apizorado

YN/nstituição: Julgamento:

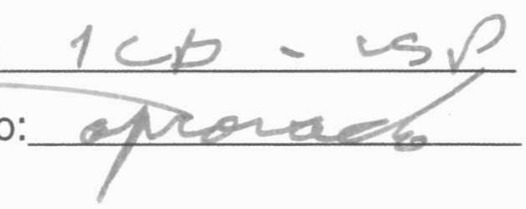

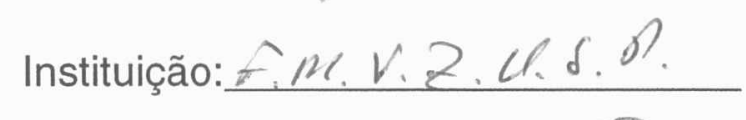

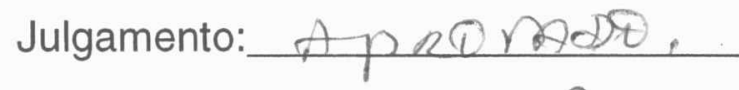
Instituição: $\operatorname{Tr} v z \cdot v 80$ Julgamento: 
Aos animais,

nossos grandes

Amigose companheiros 
Esta tese teve apoio financeiro da:

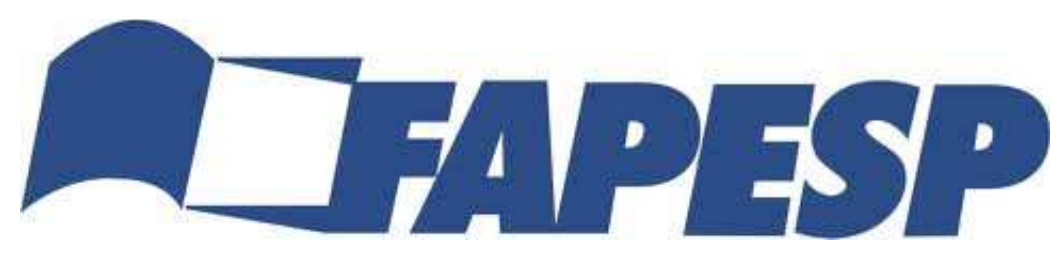

Fundação de Amparo à Pesquisa de São Paulo

Processo 2008/55534-1

Auxilio à pesquisa 2007/59391-8 
A gratidão é algo que realmente não pode faltar em nossos corações... a sensação de poder contar com "o outro" é algo indescritivel e que deve ser desfrutada ao máximo nessa nossa passagem... Um dos motivos de não estarmos sós neste mundo é esse... Podermos contar com nosso semelhante!! Seja para dividirmos as coisas simples ou as grandes questões da vida... e a gratidão é o símbolo de nossa felicidade de podermos ter dividido as nuances do cotidiano com o nosso próximo!! Por isso sou eternamente AGRADECIDO,

A Krishna, minha esposa e companheira de estrada que divide comigo os caminhos sinuosos e os serenos de nossa caminhada, e Maia, minha filha fonte inesgotável de energia para meu coração!! Gratidão eterna por dividirem suas vidas comigo... Minha família é minha fortaleza!

A minha Mãe e meu $\mathscr{P a i}$, por terem transmitido tudo que sabiam (e não sabiam) para mim e que, mesmo tendo sido "mal criado" em muitas situações, SEMPRE estiveram e estão ao meu lado ...

Aos meus Tios Sylvio e Walkyria, sem o apoio (em todos os sentidos) deles o projeto da pós na USP não teria deixado de ser um projeto.

Aos meus irmãos Marcus e Marcio por tudo que dividimos e vivenciamos juntos nos anos de convivência, com certeza foram muito importantes para minha formação. 
As minhas irmãs de coração Raquel e Tatiana, a existência de vocês faz toda diferença em minha vida... amizade fraterna autêntica!!

Ao meu grande amigo Raul e a minha nova amiga Bárbara, que os astros permitam uma longa convivência entre nossas famílias e que tenhamos cada vez mais sintonia com os sinais que a vida nos dá...

Ao meu lendário grande amigo Alexandre de Mello Delpupo ("Querida"). Outra existência que pode ser apontada como um divisor de águas em meu ser!! Todos os paradigmas e modelos construídos foram quebrados... pensar sem limites!!!

A Achiciane, por toda força profissional e amizade à minha família!!! O que você já fez por nós nunca será esquecido!!

Dos laços profissionais, que em muitas extrapolaram para amizade e admiração, gostaria de expor minha sincera gratidão a:

Minha orientadora, profa. Titular Maria Lúcia Zaidan Dagli (Malú)... Pessoa de elevadíssimo desenvolvimento tanto intelectual quanto moral... figura que sempre transmite harmonia, serenidade... comumente entrávamos pesados com as coisas do cotidiano em sua sala e saíamos flutuando!!! Esteve sempre ao meu 
Cado mesmo nos momentos mais difíceis desse curso de pós-graduação!! Os conhecimentos transmitidos não foram só em oncologia...

Ao prof. Dr. Idércio Luiz Sinhorini, o respeito e admiração por sua figura humana levarei para a eternidade!! As horas que tive oportunidade de conversar com esse verdadeiro mestre são inesquecíveis!!

Ao dr. Lluis Maria Mir, sua simplicidade e gentileza são do tamanho de sua genialidade! Conhece-lo foi uma das maiores inspirações para seguir o rumo da eletroquimioterapia...

Ao prof. Dr. Heidge Fukumasu por toda as orientações e dedicação no auxilio do desenvolvimento do projeto... com certeza foram essenciais para a execução do mesmo!

À Marguiti, gerente do "buteco"... Sua presença no laboratório faz toda a diferença, harmoniza o ambiente!!! Dividir os dias com você por esses anos foi muito especial e com certeza criou laços de amizade verdadeiros!!

Ao dr. Gregory Mennecier merci pour tout le dévouement et l'aider dans cette phase finale du projet ... si essentiel! 
As novas amigas de laboratório Marcia e Ivone, não só grandes profissionais como grandes pessoas também!

Aos fantásticos e geniais colegas de laboratório Bruno e Lucas e Tereza, o conhecimento de vocês não foi somente essencial para o desenvolvimento do trabalho, mas foi também um "certificado de segurança" de que todos os problemas poderiam ser solucionados!

A Daniel Sanches, Tarso Felipe, Mirella, Kátia Kimura e Ricardo Garé por toda ajuda que me deram... vocês foram os primeiros colegas (juntamente com a Marcia e Bruno) que conheci na USP e ajudaram muito a me sentir à vontade no lab de oncologia.

A Luciana Torres, por desde o meu estágio supervisionado ter sido sempre atenciosa e cortês comigo.

Aos demais colegas Natalia, Juliana Bahboglian, Diego, Cintia, Leandro Canesi, Fabia, por toda ajuda nestes anos, que por menor (em tempo) que tenha sido, não deixou de ser muito importante! 
As profissionais da secretaria de pós-graduação, Cláudia Lima, Daura e Marli por toda atenção, paciência e boa vontade no trato para com minha pessoa!

$\mathcal{A}$ dona Lúcia, Rosiris, Idalina e Herculano por mais que nos encontremos apenas nos corredores ou na copa, a convivência com vocês foi sempre muito agradével!

À Shilrei, Adriana, Milena, Claudia Faria, Cláudia (6iotério), sempre muito educadas e simpáticas!!

Esse espaço eu reservo para aqueles profissionais Médicos Veterinários que acreditaram em meu trabalho desde o início e abriram suas portas para mim: Cláudia Brito, Rafael Costa Jorge, Renato Bocabello, Rodrigo Vbukata, Roberta Portela, Edilva e Rodrigo Flaquer, Ana Paula Nogueira, Adriana Nishiya, José Manuel, Renato Miraca, Cintia, Juliana Perdiz, Vanessa Paiva, Fabio Toyota, Juliana Cirillo, Eloy Curuci, Vilcio Pedro, Monica Veras, José Roberto, Leon Roman, Célia (Jundaí), Carlos Fragoso, Samira, Thomas, Rafaele Dani Galesko, Adriano Barille, dr. Custódio, Thaís Pagni, Pamela e Francisco Hato Jr... me desculpem os que não citei, com certeza esqueci de muitos colegas, mas sintam-se todos agradecidos! 
Aos meus mestres responsáveis por minha formação incial em Medicina Veterinária:

Proessores Andréa Alves, Gilton almada, Fernando Tobias, Argeu, Belizário, Fernanda Toledo e Tayse, Flavia Machado, Gustavo Baioto, Rivelino Roveta e Walter Có.

Aos Meus Mestres em Física:

Professores Doutores Plinio, Brasil, Francisco Carlos Pinheiro, Laercio Ferracioli, Macos Tadeu D'Azeredo e Ricardo. Estes são meus Mestres nessa área de conhecimento!!

Aos secretários Ana e José Carlos meus sinceros agradecimentos!! 


\section{In Memorian}

A minha vó Maria e sua figura sempre acolhedora...

Ao meu avô Walter, sua figura e minha infância estarão sempre ligadas...

Zara, Dharma e Patricinha... saudades e certeza de um dia reencontra-los

Ao sr. José Antonio (sogro), embora não tenhamos convivido muito em tempo os momentos que dividimos foram muito especiais.

À Cynthia, além de uma grande profissional, pessoa de espirito elevado!! Toda minha iniciação no laboratório de oncologia devo a você que me recebeu de maneira muito acolhedora!!

Aos amigos da espiritualidade sempre prontos a me ajudar em todos os momentos!! 
"Nós seres humanos, estamos na natureza para auxiliar o progresso dos animais, na mesma proporção que os anjos estão para nos auxiliar. Portanto quem chuta ou maltrata um animal é alguém que não aprendeu a amar"

Chico Xavier 


\section{RESUMO}

RANGEL, M. M. M. Interferência da eletroporação sobre a expressão de conexinas. [Interference of electroporation on the expression of connexins]. 2011.120 f. Tese (Doutorado em Ciências) - Faculdade de Medicina e Zootecnia, Universidade de São Paulo, São Paulo, 2011.

A eletroporação é um fenômeno que promove a formação de poros na membrana citoplasmática quando esta é submetida à exposição de um campo elétrico específico. Dentre as principais aplicações da eletroporação podemos citar a eletroquimioterapia, uma nova terapia contra o câncer, e a terapia gênica, ainda em desenvolvimento. As conexinas são unidades formadoras das junções gap, canais transmembrana responsáveis pela comunicação intercelular e que participam de uma serie de eventos fisiológicos como o crescimento e diferenciação celular. A importância desta família de genes na oncologia está cada vez mais clara dadas às evidencias de seu comportamento de supressor de tumor ou como facilitador da disseminação e metástases de acordo com a fase de em que o câncer se apresenta. A eletroporação como um fenômeno que promove perturbação em membrana poderia interferir de alguma forma na expressão das conexinas. O objetivo deste trabalho foi avaliar os possíveis efeitos de interferência na expressão gênica das células promovidos pela eletroporação em especial na família de genes das conexinas. Para tanto as células foram expostas a um campo semelhante a 0 utilizado para eletroquimioterapia e avaliadas em diferentes tempos após a exposição. Três linhagens, duas neoplásicas (melanoma B16/BL6 e E9) e uma linhagem não neoplásica (E10) foram utilizadas como modelo experimental para que pudesse ser feita uma analise comparativa e a avaliação dos possíveis diferentes comportamentos das mesmas frente à eletroporação. O estudo da expressão gênica foi realizado pelas técnicas de imunofluorescência, western blot e PCR em tempo real. A Cx 26 foi avaliada na linhagem B16/BL6 e a Cx 43 nas linhagens E9 e E10. Os resultados da imunofluorescência apontaram uma marcação no citoplasma em B16/BL6, predominantemente em núcleo para a linhagem E9 e em núcleo e citoplasma em E10. Somente a linhagem E9 apresentou diferentes marcações entre os grupos, com uma marcação em citoplasma no grupo $t_{1 / 2}$ (30 minutos apos a eletroporacao) $O$ western blot mostrou diminuição transiente para as Cxs apenas nas linhagens neoplásicas nos grupos $t_{1 / 2}$ e $t_{1}$ ( 1 hora apos a eletroporacao). A 
linhagem E10 apresentou aumento de expressão nos mesmos grupos. O PCR em tempo real apresentou diferenças significativas nos tempos $t_{1 / 2}$ e $t_{1}$ para as linhagens B16/BL6 e E10. A linhagem B16/BL6 teve diminuição de RNAm enquanto a linhagem E10 apresentou aumento de transcrição de RNAm. A linhagem E9 apresentou padrão de expressão bastante heterogêneo. Frente aos resultados apresentados podemos concluir que a eletroporação interferiu de maneira transiente na expressão de conexinas.

Palavras-chave: Eletroporação. Eletroquimioterapia. Conexinas. Neoplasias. Melanoma. 


\begin{abstract}
RANGEL, M. M. M. Interference of electroporation on the expression of connexins [Interferência da eletroporação na expressão de conexinas]. $2011.120 \mathrm{f}$. Tese (Doutorado em Ciências) - Faculdade de Medicina e Zootecnia, Universidade de São Paulo, São Paulo, 2011.
\end{abstract}

Electroporation is a phenomenon that promotes the formation of pores in the cytoplasmic membrane when it is exposed to a specific electric field. The main applications of electroporation include the electrochemotherapy, a new cancer therapy, and gene therapy, still in development. Connexins are forming units of gap junctions, transmembrane channels responsible for intercellular communication and participating in a series of physiological events such as cell growth and differentiation. The importance of this gene family in oncology is increasing. The evidence of its behavior as a tumor suppressor or facilitator of dissemination and metastases according to the stage where the cancer presents itself. Electroporation as a phenomenon that promotes membrane disruption could interfere somehow in the expression of connexins. The aim of this study was to evaluate the possible effects of interference in gene expression. of cells promoted by electroporation in particular gene family of connexins. For this purpose cells were exposed to a electric field similar to that used for Electrochemotherapy and evaluated at different times after exposure. Three cell lines, two neoplastic (melanoma B16/BL6 and E9) and one line non-neoplastic (E10) were used as experimental models that could provide a comparative analysis between the lines and an assessment of the possible different behaviors due to electroporation. Its expression was assessed by immunofluorescence, western blot and real-time PCR. Cx 26 was evaluated in the melanoma cell line B16/BL6 and Cx 43 in the cell lines E9 and E10. The results showed a cytoplasm immunofluorescence staining pattern in the in B16/BL6, predominantly in the nucleus in line E9 and in the nucleus and cytoplasm for cell line E10. Only the cell line E9 had different immunoflurescence stainings between the groups, with a positivity in the cytoplasm in the group $t_{1 / 2}$. The western blot showed transient decrease of Cxs only in cell lines neoplastic in the times $t_{1 / 2}$ and $t_{1}$. The lung cell line E10 showed increased expression in the same time points. The real-time PCR showed significant differences in $t_{1 / 2}$ and $t_{1}$ for the cell lines B16/BL6 and E10. 
The melanoma cell line B16/BL6 had mRNA decreased while the cell line E10 showed increased transcription of mRNA. The cell line E9 showed a very heterogeneous expression pattern. According to our results, we can conclude that electroporation interfered transiently in the expression of connexins.

Keywords: Electroporation. Electrochemotherapy. Connexins. Neoplasms. melanoma. 


\section{LISTA DE FIGURAS}

Figura 1 - Fotomicrografia da membrana de eritrócitos após letroporação mostrando os eletroporos formados.

Figura 2 - Desenho esquemático representando a estrutura das conexinas e das junções gap.

Figura 3 - Representação esquemática dos passos de síntese, arranjo e degradação das junções gap.

Figura 4 - Representação esquemática da via de degradação das conexinas pelo endossomo precoce e endossomo tardio

Figura 5 - Fotomicrografia de crescimento isolado das células da linhagem E10.

Figura 6 - Fotomicrografia de crescimento das células da linhagem E10 já em confluência.

Figura 7 - Fotomicrografia das células da linhagem E9 já em confluência em amontoados.

Figura 8 - Fotomicrografia - IF - Cx 43 em células da linhagem E9

Figura 9 - Eletrodo para células em suspensão

Figura 10 - Esquema de ilustração de um sistema de eletroporação de células aderidas

Figura 11 - Fotomicrografia de células de melanoma da linhagem B16/BL6.

Figura 12 - Eletrodo utilizado no experimento de eletroquimioterapia.

Figura 13 - Eletrodo para eletroporação em placas de Petri de $100 \mathrm{~mm} . . . .$.

Figura 14 - Fotomicrografia - células eletroporadas com BrEt (800 V/cm)..

Figura 15 - Fotomicrografia - células eletroporadas com BrEt $(600 \mathrm{~V} / \mathrm{cm}) \ldots$

Figura 16 - Fotomicrografia - células eletroporadas com BrEt (400 V/cm)..

Figura 17 - Fotomicrografia - células eletroporadas com BrEt $(0 \mathrm{~V} / \mathrm{cm}) \ldots \ldots$.

Figura 18 - Fotomicrografia - células eletroporadas com BrEt e LaAc (800 V/vm) 
Figura 19 - Fotomicrografia - células eletroporadas com BrEt e LaAc $(1300 \mathrm{~V} / \mathrm{vm})$

Figura 20 - Melanoma implantado em camundongo................................ 79

Figura 21 - Reposta à eletroquimioterapia - 1 dia após............................. 79

Figura 22 - Reposta à eletroquimioterapia - 7 dia após.............................. 79

Figura 23 - Reposta à eletroquimioterapia - 8 dia após............................. 79

Figura 24 - Reposta à eletroquimioterapia - 12 dia após........................... 79

Figura 25 - Reposta à eletroquimioterapia - 20 dia após........................... 79

Figura 26 - Reposta à eletroquimioterapia - 27 dia após........................... 79

Figura 27 - Estudo comparativo do volume tumoral entre os grupos de tratamento.

Figura 28 - Fotomicrografia - IF - Cx 26 na linhagem B16/BL6 no grupo CT

Figura 29 - Fotomicrografia - IF - Cx 26 na linhagem B16/BL6 no grupo $t_{3}$.

Figura 30 - Proteínas totais das amostras da linhagem B16/BL6

Figura 31 - Gel e membranas - western blot Cx 26 em B16/BL6.

Figura 32 - Densitometria - Cx 26 nos diferentes grupos em B16/BL6......

Figura 33 - Expressão de mRNA para Cx 26 na linhagem B16/BL6 após eletroporação nos diferentes grupos.

Figura 34 - Fotomicrografia - IF - Cx 43 na linhagem E9 no grupo CT...... 86

Figura 35 - Fotomicrografia - IF - Cx 43 na linhagem E9 no grupo $t_{0} \ldots \ldots . .$.

Figura 36 - Fotomicrografia - IF - Cx 43 na linhagem E9 no grupo $t_{1 / 2} \ldots \ldots$

Figura 37 - Fotomicrografia - IF - Cx 43 na linhagem E9 no grupo $t_{1} \ldots \ldots .$.

Figura 38 - Fotomicrografia - IF - Cx 43 na linhagem E9 no grupo $t_{3} \ldots \ldots . .$.

Figura 39 - Fotomicrografia - IF - Cx 43 na linhagem E9 no grupo t5........ 
Figura 40 - Fotomicrografia - IF - Cx 43 na linhagem E10 no grupo ct.....

Figura 41 - Fotomicrografia - IF - Cx 43 na linhagem E10 no grupo $t_{0 . \ldots . . .}$

Figura 42 - Fotomicrografia - IF - Cx 43 na linhagem E10 no grupo $t_{1 / 2} \ldots$

Figura 43 - Fotomicrografia - IF - Cx 43 na linhagem E10 no grupo $t_{1} \ldots \ldots$.

Figura 44 - Fotomicrografia - IF - Cx 43 na linhagem E10 no grupo $t_{3} \ldots \ldots$

Figura 45 - Fotomicrografia - IF - Cx 43 na linhagem E10 no grupo $t_{5} \ldots \ldots$.

Figura 46 - Gel e membranas - western blot Cx 43 em E10

Figura 47 - Densitometria - Cx 43 nos diferentes grupos em E10

Figura 48 - Gel e membranas - western blot Cx 43 em E9

Figura 49 - Densitometria - Cx 43 nos diferentes grupos em E9

Figura 50 - Expressão de RNAm para Cx 43 na linhagem E10 após eletroporação nos diferentes grupos.

Figura 51 - Expressão de mRNA para Cx 43 na linhagem E9 após eletroporação nos diferentes grupos.

Figura 52 - Melanoma em cavidade oral - marcação do local onde foi feita aplicação da sessão de eletroquimioterapia.

Figura 53 - Remissão completa de melanoma em cavidade oral após sessão de EQT. Evidência dos efeitos seletivos ao tecido 102 Neoplásico.

Figura 54 - Mastocitoma em orelha - marcação do local onde foi feita aplicação da sessão de eletroquimioterapia

Figura 55 - Remissão completa de mastocitoma em orelha após sessão de EQT.Evidência dos efeitos seletivos ao tecido neoplásico..

Figura 56 - Melanoma implantado em dorso de camundongo - marcação do local onde foi feita aplicação da sessão de eletroquimioterapia.

Figura 57 - Remissão completa de melanoma implantado em camundongo após eletroquimioterapia. Evidência dos efeitos seletivos ao tecido neoplásico.

Figura 58 - Fotomicrografia - IF - Cx 26 na linhagem B16/BL6. 
Marcação (verde) intracitoplasmática.................................... 107

Figura 59 - Fotomicrografia - IF - Cx 43 na linhagem E9. Marcação

(vermelha) predominante em membrana............................... 107

Figura 60 - Fotomicrografia - IF - Cx 43 na linhagem E10. Marcação (vermelha) em membrana e citoplasma... 


\section{LISTA DE QUADRO E TABELAS}

Quadro 1 - Estudo da expressão das conexinas em várias amostras de tumores humanos.

Tabela 1 - Resultados de viabilidade celular pelo método de exclusão com a coloração azul de trypan

Tabela 2 - Comparação entre as respostas às terapias.

Tabela 3 - Concentração de mRNA total em E10 após eletroporação nos diferentes grupos.

Tabela 4 - Concentração de mRNA total em E9 após eletroporação nos diferentes grupos 


\section{LISTA DE ABREVIATURAS E SIGLAS}

$\begin{array}{ll}\text { CIJG } & \text { Comunicação intercelular por junções gap } \\ \text { CX } & \text { Conexinas } \\ \text { EQT } & \text { Eletroquimioterapia } \\ \text { EP } & \text { Eletroporação } \\ \text { FMVZ } & \text { Faculdade de Medicina Veterinária e Zootecnia } \\ \mathrm{g} & \text { Gramas } \\ \mathrm{IF} & \text { Imunofluorescência } \\ \mathrm{kDa} & \text { KiloDâltons } \\ \mathrm{kg} & \text { Kilograma } \\ \mathrm{M} & \text { Mol } \\ \mathrm{mg} & \text { Miligrama } \\ \mathrm{ml} & \text { Mililitro } \\ \mathrm{nm} & \text { Nanômetro } \\ \mathrm{PCR} & \text { Reação Polimerase em Cadeia } \\ \mathrm{WB} & \text { Western Blot }\end{array}$




\section{TERMOS EM INGLÊS}

cDNA - fita de ácido desorribonucléico complementar a ácido ribonucléico que contém a mensagem que codifica para determinada proteína.

DNA - ácido desoxirribonucléico.

Gap - fenda.

Overnight - período de tempo correspondente há uma noite.

PCR - reação de polimerização em cadeia.

Real Time - PCR feito no tempo real

RNA - ácido ribonucléico.

mRNA - RNA mensageiro

Turnonver - taxa de renovação 


\section{SUMÁRIO}

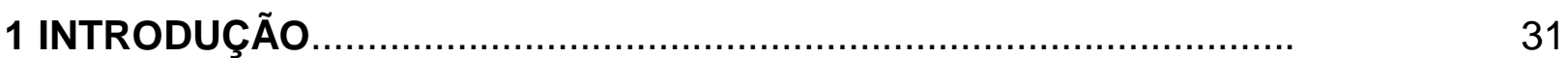

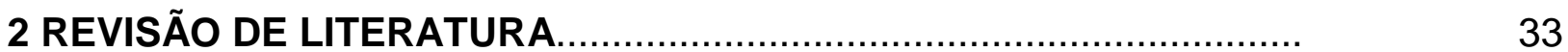

2.1 CONHECIMENTOS ATUAIS SOBRE ELETROPORAÇÃO E

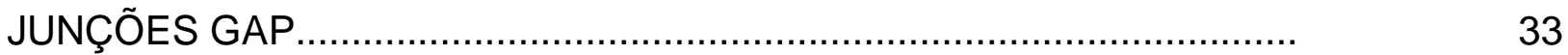

2.1.1 A eletricidade a eletroporação e a eletrquimioterapia................. 33

2.1.2 As conexinas e o câncer................................................... 34

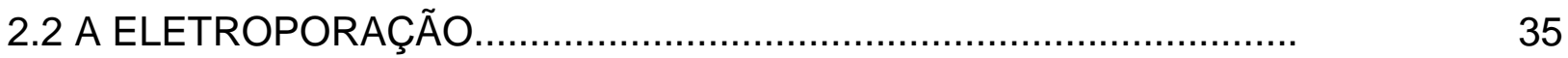

2.2.1 Fenômeno de "quebras elétricas" ....................................... 35

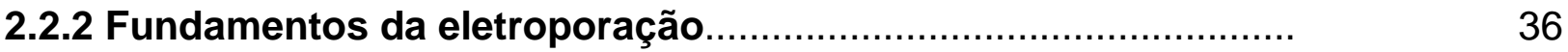

2.2.3 Permeabilidade celular e eletroporação................................... 37

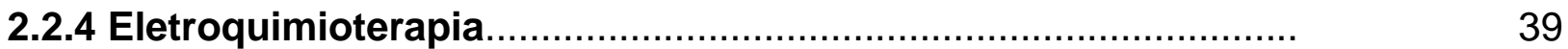

2.3 AS JUNÇÕES DO TIPO GAP E CONEXINAS.............................

2.3.1 A estrutura das junções tipo gap e as conexinas..................... 40

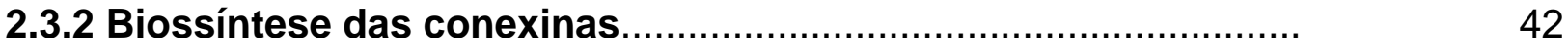

2.3.3 Degradação das conexinas...................................................

2.3.4 Turnover das conexinas.......................................................

2.3.5 Diferentes padrões de conexinas em células neoplásicas e 46 não neoplásicas

2.4 SITUAÇÃO DO ASSUNTO DE PESQUISA .................................. 48

2.4.1 A linhagem de melanoma b16/bl6........................................

2.4.2 As linhagens de células de pulmão e9 e e10............................. 50

2.4.2.1 As conexinas nas linhagens de células e9 e e10......................... 53

2.4.3 Eletroporação in vitro de células aderidas..............................

2.4.4 Interferência do fenômeno de eletroporação na expreção 
gênica.

3 OBJETIVOS

3.1 OBJETIVOS GERAIS.

3.2 OBJETIVOS ESPECÍFICOS

4 MATERIAL E MÉTODOS.

4.1 ESTUDOS IN VIVO COM ELETROPORAÇÃO: EXPERIMENTO

COM ELETROQUIMIOTERAPIA EM CAMUNDONGOS

4.1.1 Desenho experimental.

4.1.2 Camundongos da linhagem C57bl/6.

4.1.3 Linhagem de melanoma B16/F10.

4.1.4 Procedimento de eletroquimioterapia.

4.2 ESTUDOS IN VITRO COM A LINHAGEM DE MELANOMA B16/BL6.

4.2.1 Cultivo de células da linhagem b16/bl6

4.2.2 Padronização do protocolo de eletroporação.

4.2.2.1 Construção de eletrodo para realização do procedimento em placas de Petri.

4.2.2.2 Avaliação do índice de eletroporação

4.2.2.3 Análise de viabilidade celular ao protocolo de eletroporação

4.2.2.4 Protocolo de eletroporação utilizado.

4.2.3 Imunofluorescência.

4.2.4 Western blot para Cx 26 da linhagem de células

B16/BL6

4.2.4.1 Preparação das amostras. 
4.2.4.3 Quantificação das proteínas.

4.2.4.4 Eletroforese em gel de poliacrilamida..........................................

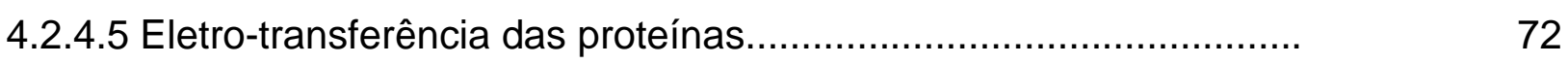

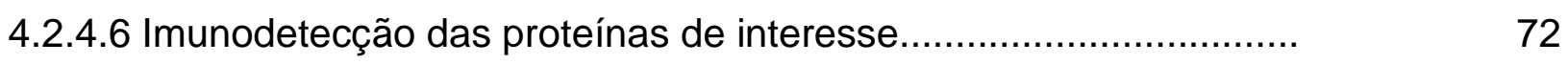

4.2.4.7 Reação da polimerase em cadeia registrada em tempo real (real time $P C R$ ) na linhagem de melanoma B16/BL6

4.3 ESTUDOS IN VITRO COM AS LINHAGENS DE CÉLULAS DE PULMÃO E9 E E10

4.3.1 Cultivo de células das linhagens E9 e E10 ..................................

4.3.2 Imunofluorescência da Cx 43 nas linhagens E9 e E10................

4.3.3 Western blot para a Cx $\mathbf{4 3}$ nas Inhagens E9 e E10......................

4.3.3.1 Stripping das membranas...........................................................

4.3.4 Reação da polimerase em cadeia registrada em tempo real (real time pcr) nas linhagens de pulmão E9 e E10......................

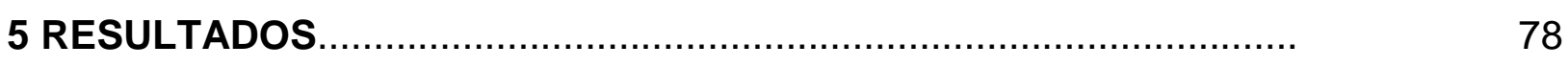

5.1 RESULTADOS DOS EXPERIMENTOS IN VIVO.....................................

5.1.1 Resposta à eletroquimioterapia para melanomas da linhagem B16/BL6 inoculados em camundongos C57/bl6 ......................... 78

5.2 RESULTADOS DOS EXPERIMENTOS IN VITRO............................

5.2.1 Resultados do experimentos envolvendo a linhagem de melanoma

B16/BL6.

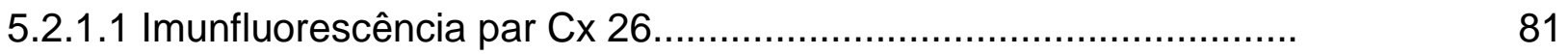

5.2.1.2 Western blot para Cx 26 na linhagem B16/BL6...........................

5.2.1.2.1 Quantificação de proteinas totais..............................................

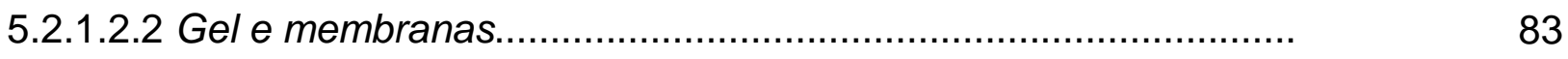


5.2.1.2.3 Quantificação de Cx 26 através da análise densitométrica das membranas para linhagem B16/BL6

5.2.1.3 PCR em tempo real para Cx 26.

5.2.1.3.1 Determinação dos níveis de transcrição de mRNA Cx 26 na linhagem b16/b/6 submetidas a eletroporação através da técnica de PCR em tempo real.

\subsubsection{Resultados dos experimentos envolvendo as linhagens de} pulmão E9 e E10.

5.2.2.1 Imunofluorescência para Cx 43 na linhagem E9.

5.2.2.2 Imunofluorescência para Cx 43 na linhagem E10.

5.2.2.3 Western blot para Cx 43 na linhagem E10

5.2.2.3.1 Gel e membranas para a linhagem E10.

5.2.2.3.2 Quantificação da Cx 43 através da análise densitométrica das membranas para a linhagem E10

5.2.2.4 Western blot para Cx 43 na linhagem E9.

5.2.2.4.1 Gel e membranas para a linhagem E9.

5.2.2.4.2 Quantificação da Cx 43 através da análise densitométrica das membranas para a linhagem E9.

5.2.2.5 PCR em tempo real para Cx 43 na linhagem E10

5.2.2.5.1 Extração e quantificação do mRNA total das amostras da linhagem de células E10.

5.2.2.5.2 Resultados do PCR em tempo real para Cx 43 na linhagem de células E10.

5.2.2.6 PCR em tempo real para Cx 43 na linhagem E9.

5.2.2.6.1 Extração e quantificação do mRNA total das amostras da 
linhagem de células E9.

5.2.2.6.2 Resultados do PCR em tempo real para Cx 43 na linhagem de células E9.

6 DISCUSSÃO.

7 CONCLUSÕES. 


\section{INTRODUÇÃO}

$S$ efeitos da eletricidade nos organismos vivos estão cada vez mais em evidência na literatura científica. Com a evolução do conhecimento científico, modelos que descrevem a fenomenologia envolvida nos fenômenos elétricos, suas interações com o nosso organismo e suas possíveis aplicações vem sendo desenvolvidos(GATENBY; FRIEDEN, 2010). É notória hoje, a presença da eletricidade como ferramenta indispensável em nosso dia-dia através de suas aplicações. Em virtude disso estamos constantemente expostos a campos eletromagnéticos. Suas interações com organismos vivos e em especial com o nosso organismo tem sido tema de trabalhos de pesquisa, como por exemplo, a relação entre o uso de aparelhos celulares, que nos expõe de maneira freqüente a campos eletromagnéticos, e o aumento do risco de câncer no cérebro (GROUP, 2010; INSKIP et al., 2010). Embora existam indícios, tanto in vivo, quanto in vitro, dados conclusivos sobre os malefícios sobre a saúde humana de campos eletromagnéticos ainda estão a ser esclarecidos(LERCHL, 2009; DE VOCHT, 2010).

No estudo do câncer, a eletricidade e seus efeitos também contribuem bastante na medicina, através de meios de diagnostico, tratamento e na pesquisa cientifica. Inúmeros são os exemplos que, se não usam-na como principio direto, utilizam-na indiretamente no funcionamento de seus dispositivos. Nas ultimas duas décadas o fenômeno elétrico da eletroporação foi utilizado como um dos princípios em uma nova modalidade de tratamento contra o câncer, a eletroquimioterapia (MIR, 1994; HELLER et al., 1997). Primeiramente utilizado para realização de experimentos de transfecção gênica, alguns pesquisadores se valeram do principio da eletroporação, que promove aumento da permeabilidade da membrana citoplasmática quando esta é submetida a um campo elétrico específico, para desenvolver essa nova modalidade de tratamento(NEUMANN et al., 1999; MIKLAVCIC et al., 2000). A eletroquimioterapia associa os princípios de uma quimioterapia no seu conceito tradicional com o fenômeno de eletroporação para potencializar os efeitos de agentes antineoplásicos pouco permeáveis a membrana da célula(MIR; ORLOWSKI, 1999; KOS et al., 2010). 
Diversas triagens clínicas já foram feitas e a técnica hoje se difunde pelo mundo tanto em medicina humana quanto veterinária(KIS et al., 2010; KOS et al., 2010; LANDSTRÖM et al., 2010; TESTORI et al., 2010). Com a disseminação da técnica mais estudos sobre seus princípios vem sendo sido desenvolvidos e o fenômeno da eletroporação cada vez mais estudado. Recentemente um estudo sobre a interferência do fenômeno de eletroporação na expressão gênica das células foi desenvolvido. Os resultados apontam que a eletroporação promove sim interferência em alguns genes que participam da síntese da proteínas e também em genes da família HSP (heat shock protein)(MLAKAR et al., 2009).

O estudo das conexinas em grupos de pesquisa de oncologia vem ganhando proporções cada vez maiores, uma vez que os trabalhos mostram a grande importância dessa família de genes no processo de desenvolvimento do câncer e no desenvolvimento de metástases, de acordo com o estagio de progressão tumoral(ZHAO; DENG, 2007; CRONIER et al., 2009; NAUS; LAIRD, 2010). Como unidades formadoras das junções gap, canais localizados na membrana que realizam comunicação intercelular e são responsáveis por processo como proliferação, diferenciação e homeostase celular (VINKEN et al., 2006; DAGLI; HERNANDEZ-BLAZQUEZ, 2007), perturbações na membrana citoplasmática poderiam vir a trazer algum desequilíbrio na expressão das conexinas e também na comunicação intercelular através das junções gap.

A proposta desse trabalho é através de experimentos in vitro verificar se o fenômeno de eletroporação como um processo que promove perturbação na membrana das células, pode interferir de alguma forma na expressão das conexinas. Para isso, além da utilização das ferramentas de biologia molecular aplicadas a patologia experimental, foram realizados experimentos in vivo para que a observação da técnica de eletroquimioterapia nos auxiliasse a compreender de forma contextualizada a ação do fenômeno de eletroporação em organismos vivos. 


\section{REVISÃO DE LITERATURA}

Os temas bordados nesta revisão de literatura serão abordados nos seções específicas abaixo.

\subsection{CONHECIMENTOS ATUAIS SOBRE ELETROPORAÇÃO E JUNÇÕES GAP}

A eletroporação e as junções gap são os assuntos principais dessa tese de doutorado. As seções abaixo discorrem sobre os fundamentos necessários para uma melhor compreensão do trabalho de pesquisa.

\subsubsection{A eletricidade a eletroporação e a eletroquimioterapia}

Há pelo menos três mil anos a eletricidade vem sendo utilizada com fins terapêuticos, como descreveu Gaius Plinius Secundus (23-79 DC) em sua obra História Natural, na utilização em dores de cabeça e gota (BASFORD, 2001). Os primeiros relatos do efeito antitumoral associado ao uso de corrente elétrica datam do final do século 18, com o uso de corrente contínua de baixa intensidade (NILSSON et al., 2000). Já do meio para o final do século estudos mais elaborados sobre as possíveis aplicações terapêuticas e os mecanismos envolvidos foram realizados. Na década de 80 começa então a ser desenvolvida uma técnica de combate ao câncer que se apropria de um fenômeno bem conhecido dos laboratórios de pesquisa, a eletroporação. Desse fenômeno nasceu a eletroquimioterapia, uma técnica hoje em franca expansão pelo mundo tanto em medicina humana quanto em medicina veterinária (CEMAZAR et al., 2008; KOS et al., 2010). A fenomenologia envolvida nessa nova técnica é alvo de diversos temas de pesquisa e sua compreensão já proporciona o desenvolvimento da terapia gênica, vacinas dentre outras aplicações (HELLER, R. et al., 1997; MIKLAVCIC et al., 2000; GEHL, 2005). Diversos estudos clínicos em países como França, Eslovênia, Dinamarca, Irlanda, Itália, Estados Unidos da América, Japão, México, Áustria, Austrália já foram realizados com a eletroquimioterapia (SERSA et al., 2008b). Os resultados deste trabalho, coordenados pelo Dr. Lluis Maria Mir do Instituto Gustave-Roussy, serviram de base para definir os padrões operacionais de procedimentos de eletroquimioterapia em humanos que foi denominado projeto 
ESOPE (European Standard Operating Procedures of Electrochemotherapy) (MIR, L. M. et al., 2003; CEMAZAR et al., 2008).

\subsubsection{As conexinas e o câncer}

A correlação entre a expressão das conexinas e o câncer é um assunto que vem sendo estudado há muito tempo, já sendo descrito em 1966 que células cancerosas estudadas por eles não apresentavam comunicação por GJ (LOEWENSTEIN, 1966). A perda ou diminuição da função das GJ, frequentemente associada à mudança de expressão das conexinas, participa da progressão de uma variedade de tumores. Os tipos de conexinas, que tiveram sua expressão alterada, variam de acordo com o tipo de neoplasia. (HAASS et al., 2004). Raramente são observadas mutações em genes que codificam as conexinas, por isso a perda das comunicações intercelulares por GJ parece estar envolvida em aberrantes localizações ou expressões destas(LI; HERLYN, 2000). Diversas pesquisas têm demonstrado também que a comunicação intercelular por GJ em células cancerosas é deficiente seja por baixa expressão das conexinas, tráfico alterado para a membrana celular destas ou baixa habilidade para formar junções gap funcionais (KING, T.; BERTRAM, 2005). Dois dos maiores mecanismos que podem estar envolvidos na baixa regulação das conexinas são a metilação dos genes que a codificam e a fosforilação pós-tradução da própria conexina (CHIPMAN et al., 2003). A interferência das modificações observadas nas GJ e conexinas durante a proliferação celular geralmente resulta em diminuição nas comunicações intercelulares por GJ, porém a relevância funcional destas alterações neste processo ainda é tema de grande debate(VINKEN et al., 2006). Alguns experimentos têm sugerido que as conexinas exerçam influência na proliferação celular por mecanismos dependentes da comunicação por GJ e também por outros independentes (ZHANG et al., 2003). Desta forma as conexinas teriam influência na proliferação celular não só por serem subunidades formadoras das GJ, que são canais para inúmeros moduladores da proliferação celular, mas também por sua própria presença ou parte de sua molécula, que atuaria diretamente no controle da expressão gênica e desta forma no crescimento celular. Ainda existem muitas questões a respeito da interferência das conexinas na proliferação celular, mas o 
que se observa nas neoplasias, embora muitas exceções venham sendo relatadas, é uma redução na comunicação por GJ. Substanciais evidências sugerem que uma sustentada baixa regulação das comunicações intercelulares por GJ forneça um estímulo promotor de neoplasias (CHIPMAN et al., 2003). Outro fato observado é que a deficiência de conexinas aumenta a susceptibilidade tanto para carcinogênese espontânea quanto para induzida quimicamente, embora a inibição do crescimento causada por transfecção de genes que codificam conexinas, nem sempre esteja associada ao aumento da atividade das comunicações por GJ (VINKEN et al., 2006).

\subsection{A ELETROPORAÇÃO}

Esta seção se destina especificamente aos conceitos e fundamentos sobre eletroporação essenciais a uma melhor compreensão deste trabalho de pesquisa.

\subsubsection{Fenômeno de quebras elétricas}

O fenômeno de "quebras elétricas" reversíveis na membrana celular, mais tarde definido como eletroporação ou eletropermeabilização, foi relatado já no fim da década de 50. Quase uma década depois foi promovida a destruição não térmica de microorganismos submetidos a altos pulsos elétricos. No inicio da década de 70 experimentos determinaram um grande aumento da permeabilidade de vesículas submetidas a pulsos elétricos (NEUMANN; ROSENHECK, 1972). No inicio da década de 80 foram realizadas as primeiras transferências de genes utilizando pulsos elétricos e finalmente no fim da década de 80 , foi observado o aumento da citotoxidade da bleomicina in vitro e in vivo com o uso de pulsos elétricos, o que viria a ser denominada posteriormente eletroquimioterapia (NEUMANN et al., 1982; MIKLAVCIC, D. et al., 2010). A eletroporação é um processo conhecido há aproximadamente 20 anos que tem como objetivo facilitar a entrada na célula, de moléculas normalmente não permeáveis à membrana plasmática (GOTHELF et al., 2003). Atualmente este processo tem sido amplamente utilizado em biologia molecular, biotecnologia e medicina no transporte de genes e drogas para dentro das células (KANDUSER et al., 2006). Dentre as aplicações mais promissoras da eletroporação podemos destacar a transferência de DNA, por ser esse eficiente, seguro e não viral, para terapia genética (MIKLAVCIC, D. et al., 2010) e a 
eletroquimioterapia no tratamento do câncer (SATKAUSKAS et al., 2005). Recentemente a eletroporação foi associada com sucesso à terapia fotodinâmica, in vitro, com objetivo de aumentar os níveis de fotosensibilizadores nas células tumorais (LABANAUSKIENE et al., 2007). O procedimento de eletroporação consiste basicamente na exposição do tecido ou células aos pulsos elétricos por meio de eletrodos (MIR, L. M., 2001; COROVIC et al., 2008).

A geometria dos eletrodos deve ser de tal maneira que proporcione uma aplicação homogênea e constante dos pulsos elétricos no tecido ou meio de cultura. Existe um grande número de eletrodos sendo utilizados no processo de eletroporação para eletroquimioterapia, podendo estes ser em forma de placas ou em forma de agulhas equidistantes. In vitro são utilizadas cubetas próprias para este tipo de procedimento. Os principais materiais utilizados para construção dos eletrodos são o alumínio e o aço, sendo este último o mais utilizado (COROVIC et al., 2008).

\subsubsection{Fundamentos da eletroporação}

Quando uma célula é submetida a um campo elétrico, uma voltagem transmembrana é induzida. Se esta voltagem transmembrana induzida atingir valores maiores que a diferença de potencial de repouso da membrana, começa-se a observar um aumento de permeabilidade (GOWRISHANKAR; WEAVER, 2006). Este fenômeno é denominado eletroporação ou eletropermeabilização (FLISAR et al., 2003). Os poros serão inicialmente gerados onde o campo elétrico induzido superar a diferença de potencial transmembrana, descrito como sendo aproximadamente $200 \mathrm{mV}$ para células eucarióticas por Tessie e Rolls em 1993 (GEHL, 2003). O que determinará a área de eletroporação é a intensidade do campo induzido e o que definirá o tamanho do poro é o tempo de duração e o número de pulsos (PUC et al., 2004). Observa-se também que os poros se formarão primeiramente no pólo positivo do eletrodo, devido potencial no interior da célula ser negativo, sendo então este o local onde a capacitância a membrana será excedida primeiro. Outra característica que tem se observado é que os maiores poros se formarão na face oposta a face onde se encontra o eletrodo positivo(USAJ et al., 2010). Os maiores poros são os responsáveis pela entrada das maiores moléculas, como a do DNA, que podem precisar de forças de eletroforese para entrar(GEHL, 
2003). A eletroporação está fortemente relacionada com o padrão de amplitude, duração, freqüência, número e forma do pulso elétrico aplicado (LEBAR et al., 2002). Os poros formados pelo campo elétrico aplicado poderão ser reversíveis, mantendo a viabilidade da célula após a aplicação(KRAMAR et al., 2007). Se os valores de amplitude e duração, excederem determinados padrões de pulso elétrico suportáveis pela membrana os poros se tornam irreversíveis desencadeando a morte da célula(PUC et al., 2004). Os poros formados pela eletroporação permitem que moléculas de peso molecular com valores acima de $30.000 \mathrm{Da}$, normalmente não permeáveis penetrem na célula (GOTHELF et al., 2003). Enquanto a formação dos poros se dá quase que imediatamente a aplicação do campo elétrico, seu fechamento pode demorar de alguns segundos a minutos(PLIQUETT et al., 2007). A exposição de tecidos, in vivo, ao campo elétrico pelo processo de eletroporação também promove outro fenômeno que é uma transiente diminuição do fluxo sanguíneo, possibilitando um maior tempo para penetração de drogas e outras moléculas pelos poros formados(SERSA et al., 2008a). Isso proporciona uma maior concentração intracelular de uma droga que esteja circulante, no tecido exposto(PEYCHEVA et al., 2007).

\subsubsection{Permeabilidade celular e eletroporação}

Células submetidas a um campo elétrico externo específico tem apresentado aumento de sua permeabilidade, o que se denominou eletropermeabilização ou eletroporação(WEAVER, 1995b; GEHL, 2003). Utiliza-se este último nome, pois foi creditado a formação de poros na membrana, após a exposição ao campo elétrico, a razão do aumento de permeabilidade na membrana. Embora não existam evidencias físicas que poros são criados na membrana da célula(CHANG; REESE, 1990; CHERNYSH et al., 2009). As bases teóricas que sustentam esse modelo predizem que as forças elétricas suplantam as forças dielétricas das interações hidrofóbicas da membrana(DANDO; CHEN, 2008). Experimentos com a técnica de congelamento rápido e microscopia eletrônica por crio-fratura mostraram evidencias da criação de poros na membrana após exposição a um campo elétrico especifico, similar aos utilizados em protocolos de eletroporação. A figura 1 mostra fotos de microscópio eletrônico por criofratura dos possíveis poros formados em diferentes tempos após a aplicação do campo elétrico (CHANG; REESE, 1990). 


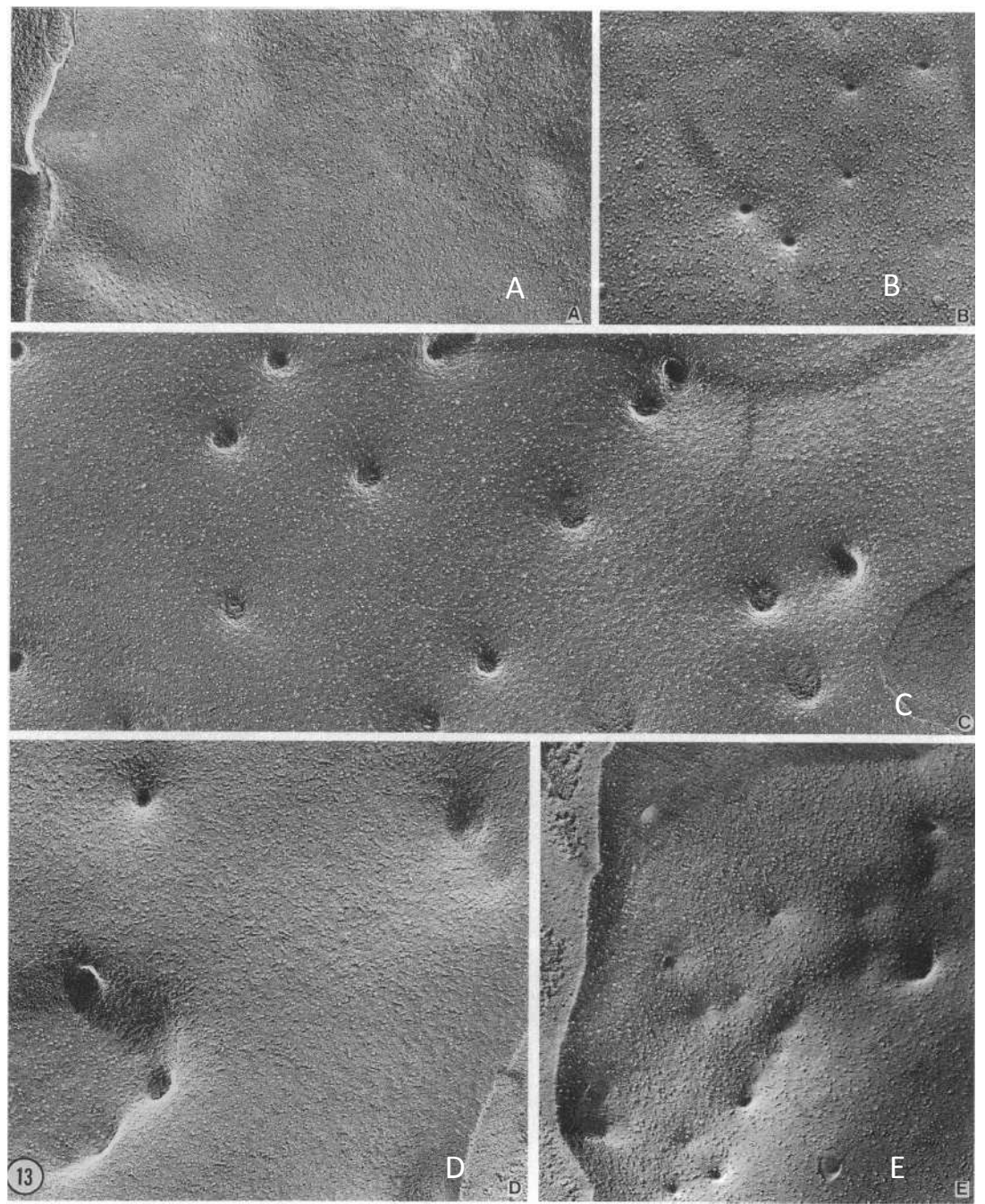

Figura 1 - Micrografia (microscopia eletrônica de varredura) mostrando a estrutura da membrana celular (face externa) de eritrócitos congelados em diferentes tempos após eletroporação. (A) 0,5 ms, (B) $3 \mathrm{~ms}$, (C) $40 \mathrm{~ms}$, (d) $5 \mathrm{~s} \mathrm{e} \mathrm{(E)} 10 \mathrm{~s}$. 60000x. (CHANG; REESE, 1990)

A criação de poros na membrana possibilita a troca de substancias do meio intracelular com o meio extracelular, o que poderia ser motivo de lesões e até mesmo morte das células (DANDO; CHEN, 2008). Os mecanismos de restauração das homeostase celular também ficam prejudicados com o desbalanço de concentração dos solutos do meio intracelular, porém à medida que a membrana vai se reestabelecendo, lentamente a célula vai se recuperando até atingir novamente sua condição fisiológica (TSONG, 1991). Se o processo de eletroporação for irreversível, como os mecanismos de regulação da homeostasia celular ficam prejudicados com o aumento da permeabilidade promovida pelos eletroporos, à célula não conseguirá se reestabelecer e morrerá. Isso ocorre principalmente pelo desbalanço iônico e perda de ATP, sendo este último um importante motivo, uma 
vez que os mecanismos de manutenção de vida da célula são dependentes de seus estoques (TSONG, 1991; KANDUSER et al., 2006; DANDO; CHEN, 2008).

O reestabelecimento das membranas pode variar de acordo com a intensidade do campo aplicado. Esse tempo de reorganização das membranas varia de milissegundos a minutos (WEAVER, 1995a; VALIC et al., 2003).

\subsubsection{Eletroquimioterapia}

À combinação de quimioterapia sucedida de eletroporação denominou-se eletroquimioterapia, uma nova modalidade de terapia antineoplásica (CEMAZAR et al., 2008). O processo consiste em potencializar a ação de uma droga, antes com baixa ou nenhuma permeabilidade na membrana da célula, aumentando sua permeabilidade através do fenômeno de eletroporação (TESTORI et al., 2010). A bleomicina, uma droga de alto poder citotóxico intrínseco, porém impermeável à membrana teve seu efeito aumentado, in vitro, cerca de 8000 vezes com a eletroporação (MIR, L. M., 2001). Esta droga, sem eletroporação, é internalizada na célula por endocitose mediada por proteína carreadora. Desta forma seu transporte para dentro da célula depende da quantidade de exposição destas proteínas na membrana celular e da velocidade com que elas são endocitadas. Outra droga também utilizada em eletroquimioterapia é a cisplatina, que é pouco permeável a membrana e teve seu efeito potencializado in vitro cerca de 80 vezes com a eletroporação (MIR, L. M.; ORLOWSKI, 1999). A eletroquimioterapia é uma técnica de tratamento localizado de diversos tipos de tumores sólidos, sejam eles cutâneos ou subcutâneos (MIR, L. et al., 1998; MIR, L. M. et al., 2003; SERSA; MIKLAVCIC, 2008). Pelas bases físico-quimicas descritas anteriormente pode-se notar que teoricamente o tratamento é eficiente em todos os tumores em que se consiga realizar o procedimento, embora não existam dados suficientes para se demonstrar esta afirmação (MIR, L. M.; ORLOWSKI, 1999). 


\subsection{AS JUNÇÕES DO TIPO GAP E CONEXINAS}

Esta seção se refere exclusivamente a o tema conexinas e junções gap. Nela estão contidos os conhecimentos necessários para que se tenha uma melhor compreensão desse trabalho de pesquisa.

\subsubsection{A estrutura das junções do tipo GAP e as conexinas}

As junções gap (GJ), descritas inicialmente na década de 60 (MESNIL, 2002), desempenham uma série de funções biológicas, como homeostase, morfogênese, diferenciação e controle do crescimento celular. Desta forma estes importantes canais de comunicação intercelular participam tanto da manutenção de tecidos normais como do desenvolvimento de neoplasias (LI; HERLYN, 2000; TORRES et al., 2005). As GJ são canais entre células adjacentes que transportam moléculas com peso molecular de até aproximadamente $1000 \mathrm{Da}$, como íons, segundos mensageiros e metabólitos (CHIPMAN et al., 2003). O fluxo de moléculas através das GJ é considerado um mecanismo chave em praticamente todos os processos do ciclo da vida de uma célula (VINKEN et al., 2006). As GJ, embora não sejam idênticas em todos os tecidos, são formadas por seis unidades básicas chamadas conexinas (Cx). As conexinas formam os conéxons, que são hemi-canais transmembrana. A ligação face a face de dois conéxons entre células forma então uma GJ (TORRES et al., 2005). As GJ podem ser formadas por conéxons idênticos, chamados homotípicos, ou diferentes, heterotípicos. Os conéxons podem também ser formados por conexinas diferentes, chamados heteroméricos, ou iguais, denominados homoméricos (LI; HERLYN, 2000). Apesar de existirem estudos demonstrando a existência de conéxons formados por conexinas iguais e diferentes, nem todas a conexinas são compatíveis para formação de um conéxon (HAASS et al., 2004). As conexinas possuem uma estrutura semelhante composta de quatro domínios transmembrana, duas voltas em domínio extracelular, uma volta no citoplasma e duas extremidades citosólicas, uma N-terminal, e outra C-terminal, conforme mostra a figura 2 (VINKEN et al., 2006). 


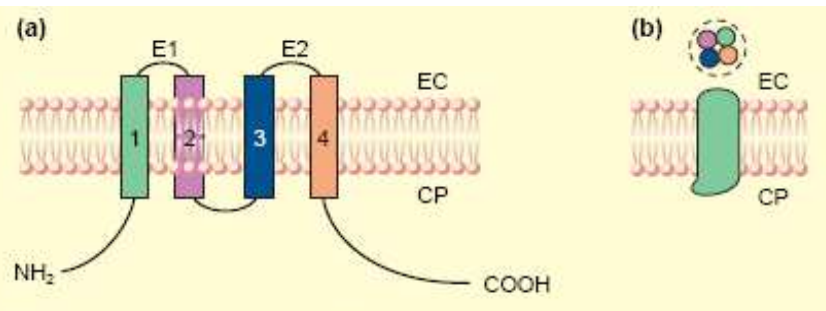

(c)

(d)

Figura 2 - (a)Topologia transmembrana de uma conexina. (b) Vista superior e vista lateral de uma conexina. (c) Vista superior de um conéxon. A região três (em azul) da conexina é formada por aminoácidos hidrofóbicos e está alinhada para formar o interior do canal.(d) Conéxon homomérico e heteromérico (e) GJ homotípicas e heterotípicas respectivamente (fonte: (LI; HERLYN, 2000).

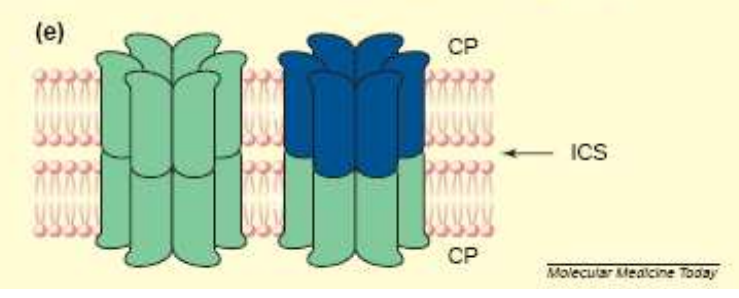

Os tipos de conexinas que formam as GJ influenciam sua seletividade e desse modo controla a especificidade da comunicação intercelular das GJ (HAASS et al., 2004). Com relação às nomenclaturas, dois sistemas classificam as conexinas. Um sistema é baseado no comprimento e similaridade da seqüência do domínio intracitoplasmático. Neste sistema é usado o prefixo GJ, as letras $\alpha, \beta, \gamma$ ou $\delta$ de acordo com as características citadas anteriormente e ainda um sufixo numérico de acordo com a ordem de descoberta. Outro sistema de classificação, sendo o inclusive o mais usual, é baseado no peso molecular da conexina. Neste sistema utiliza-se um prefixo $\mathrm{Cx}$ seguido do número de peso molecular da conexina (LI; HERLYN, 2000). 


\subsubsection{Biossíntese das conexinas}

A regulação da expressão das proteínas integrais de membrana, assim como das conexinas, é feita de uma maneira bem controlada e envolve uma série de mecanismos conforme mostrado na figura 3 (VANSLYKE; MUSIL, 2003). Podemos destacar que, obedecendo à especificidade dos padrões específicos dos diferentes tecidos, o padrão de expressão de proteínas obedece às vias regulatórias que controlam sua síntese, trafego intracelular, arranjo e degradação (MUSIL et al., 2000; SEGRETAIN; FALK, 2004).

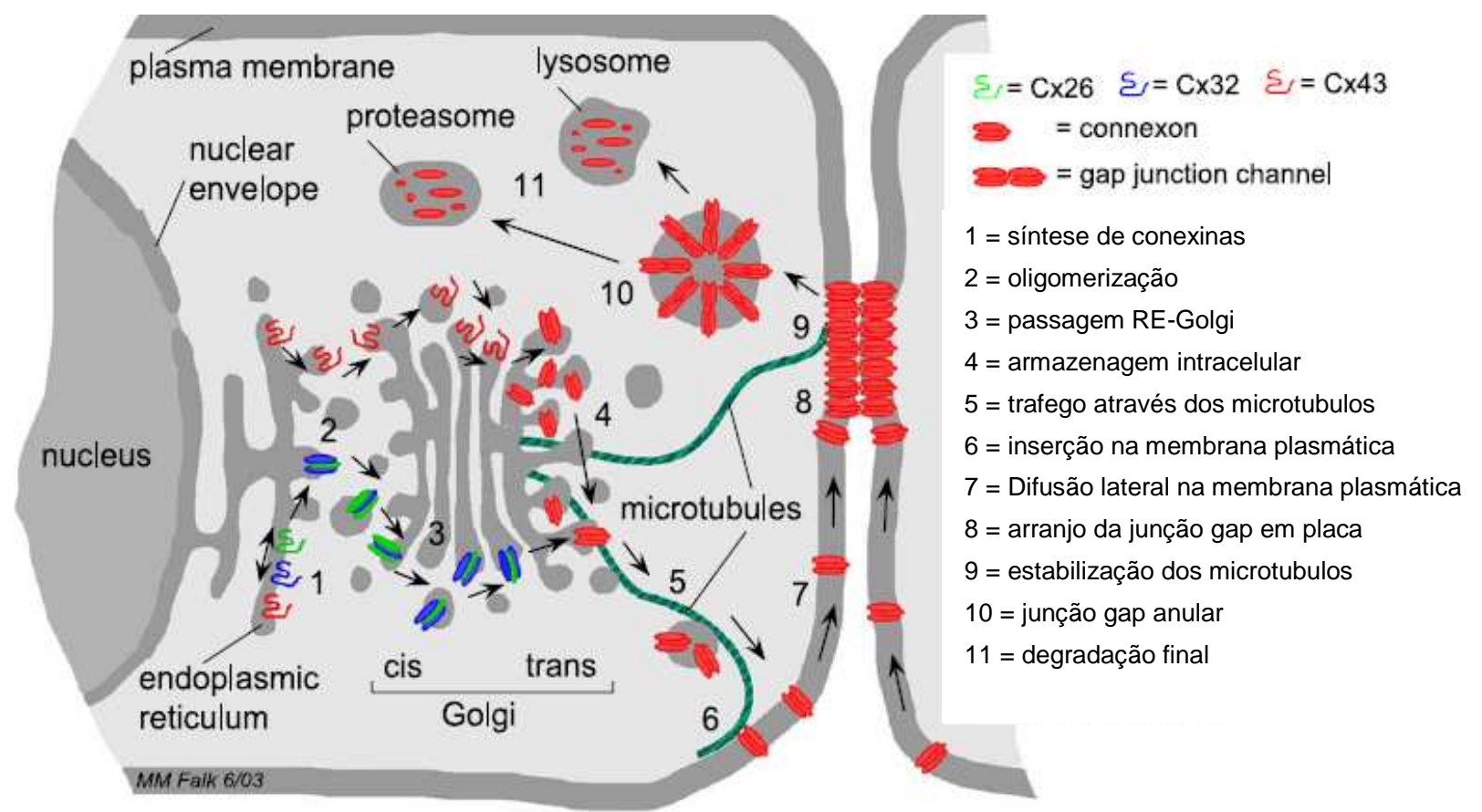

Figura 3 - Representação esquemática dos passos de síntese, arranjo e degradação das junções gap. A biosntese e degradação das junções gap envolvem (1) a síntese de conexinas na membrana do reticulo endoplasmático, (2) oligomerização em homo e heteromericos conéxons, (3) passagem através do complexo de Golgi, (4)armazenamento intracelular dentro da membrana trans Golgi, (5) trafego através dos microtubulos, (6)inserção dos conéxons na membrana plasmática, (7)Difusão lateral dos conexons na membrana plasmática, (8) agregação individual de canais intercelulares tipo junção gap, (9) estabilização das junções gap nos microtubulos, (10) internalização da placa de canais na forma de junções anulares e (11) completa degradação através das vias lisossomal e proteassomal (SEGRETAIN; FALK, 2004).

A biossíntese de conexinas começa quando mRNA para Cxs é inserido para tradução no retículo endoplasmático e depois é transportado para o complexo de Golgi e posteriormente transportado para a membrana plasmática (DE MAIO et al., 2002; HERVÉ et al., 2007). A síntese propriamente dita das conexinas ao que tudo indica passa pelo complexo de Golgi, conforme indicado pela figura 3, porém existe uma via ainda a esclarecer da Cx26 que parece ter uma via independente do Golgi. O processo de oligomerização das conexinas para formação dos conéxons anda é 
tema de debate, onde alguns pesquisadores atribuem ao reticulo endoplasmático (RE) essa função, outros ao complexo de Golgi e outros a uma região especializada do RE, os CIREG (compartimentos intermediários entre o RE e o Golgi) (LAMPE; LAU, 2000; LAIRD, 2005).

\subsubsection{Degradação das Cxs}

As principais vias de degradação das Cxs são a via lisossomal e a proteossomal. Após a síntese, oligomerização em conéxons, trafego para a membrana e formação das placas juncionais, se inicia o processo de degradação das conexinas (LAIRD, 2005; LEITHE; RIVEDAL, 2007). Primeiramente ocorre endocitose das junções gap, e dos fragmentos de membrana das duas células que formavam a junção gap. A essa vesícula dá-se o nome de conexossomo, ou junção gap anular, uma vesícula pentalaminar com dupla membrana, originada de fragmentos das membranas e das junções gap das duas células envolvidas. A forte interação entre os conéxons é responsável pela não dissociação nesse processo. $O$ conexossomo pode se fundir com um lisossomo e desta forma promover a degradação direta das junções gap e na sequencia das conexinas que as formavam. Outra via de degradação ocorre com a maturação do conexossomo para dentro de um endossomo multivesicular. Nessa via ocorre o trafego das conexinas do endossomo precoce para o tardio, antes da degradação das conexinas nos lisossomos, conforme ilustrado na figura 4 (VANSLYKE; MUSIL, 2003; SEGRETAIN; FALK, 2004). A via proteassomal embora ainda não tenha sido completamente elucidada parece estar envolvida na via de degradação de conexinas em estado não fosforilado (SPRAY, 1998; HERVÉ et al., 2007; KJENSETH et al., 2010). 


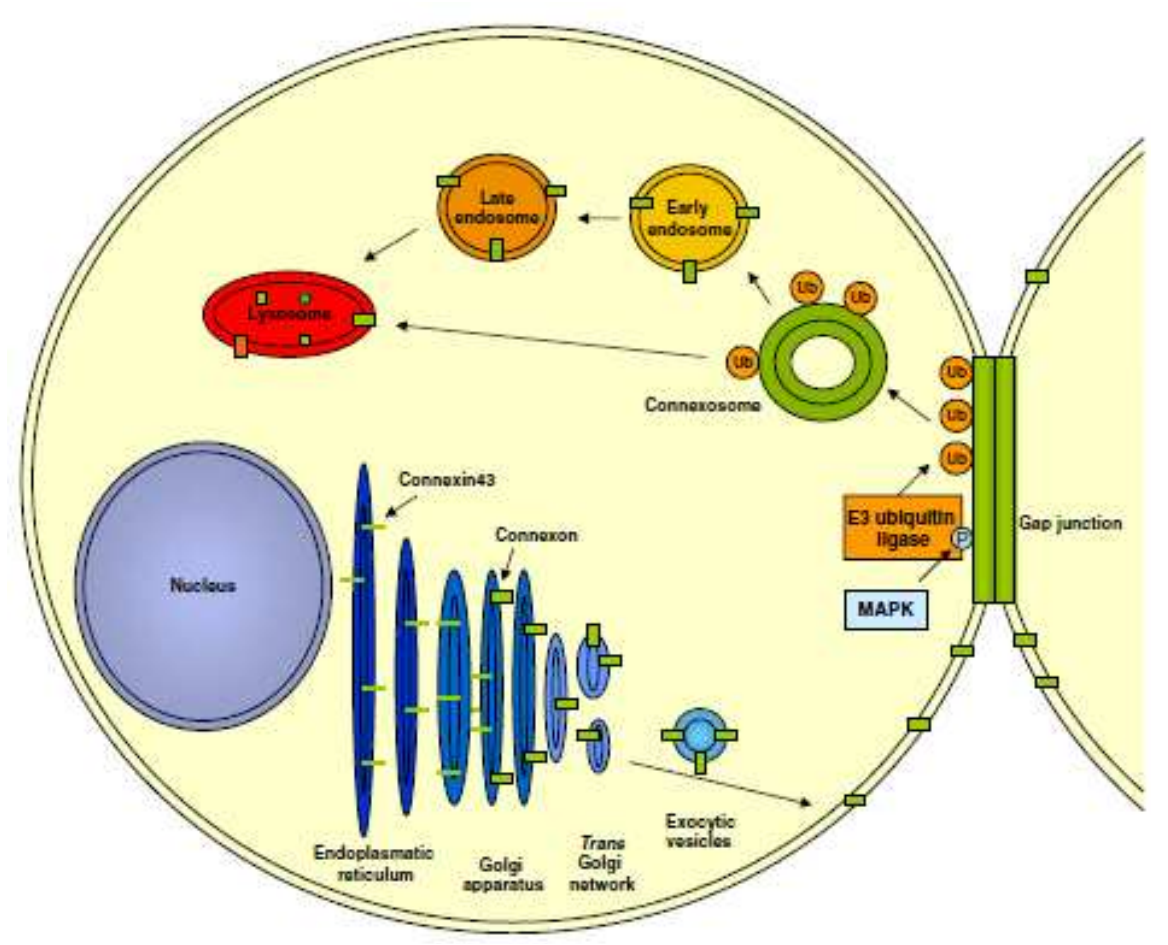

Figura 4 - llustração da via de degradação das conexinas pelo endossomo precoce (early endosome) e endossomo tardio (late endosome) (LEITHE; RIVEDAL, 2007).

\subsubsection{Turnover das conexinas}

O processo de renovação de muitos canais de membrana, entre eles das junções gap, exibe um padrão relativamente rápido, e isso tem referencia direta com a síntese e degradação das proteínas que os compõe (SAFFITZ et al., 2000). Esse comportamento também pode estar envolvido na regulação de sua atividade. Os processos de síntese e degradação estão estreitamente relacionados com a estabilidade das proteínas (SEGRETAIN; FALK, 2004). A expressão de uma determinada proteína em uma célula depende de uma fina regulação entre vários processos tais como a transcrição gênica, processamento do mRNA, síntese e arranjo da proteína, modificações pós-traducionais, transporte para a superfície da célula, ancoragem ao citoesqueleto, regulação da endocitose e degradação controlada da proteína (BEARDSLEE et al., 1998; HERVÉ et al., 2007).

Diferentes tipos celulares podem apresentar meia-vida $\left(t_{1 / 2}\right)$ diferente para as mesmas proteínas. Isso pode estar envolvido com a cinética de degradação e 
síntese de proteínas e também com o turnover da proteína em questão (HERVÉ et al., 2007).

Distúrbios no metabolismo celular como, por exemplo, a acidificação do citosol e aumento da concentração de glicose podem alterar a expectativa de vida das Cxs. Em relação a variações de temperatura e expectativa de vida das Cxs este fator não parece ser importante em homeotermos, situação que parece exercer influencia em pecilotermos.

Outro fator que está envolvido na meia vida das conexinas é a fosforilação (LAMPE; LAU, 2004). A fosforilação é uma ferramenta pós-traducional muito relevante na fisiologia celular e que é explorado pela natureza em diversas vias como mecanismo controlador em processos como proliferação e diferenciação celular, atividade enzimática, formação e degradação de complexos proteicos, motilidade, dentre outros, parece ser muito importante na meia vida das Cxs (SÁEZ et al., 1998; LAMPE; LAU, 2000; KING, T. J.; LAMPE, 2005). Os mecanismos envolvidos na regulação da formação junções gap através da fosforilação das conexinas são bem complexos e dependem da conexina e kinase específicos envolvidos e dependendo da conexina seu efeito pode ser tanto de aumento quanto de diminuição de sua meia-vida (LAMPE; LAU, 2004).

Em um balanço geral, uma vez que as conexinas têm meia-vida menor que a meia-vida da célula sua taxa de renovação é essencial para o balanço homeostático celular e certamente seu turnover está intimamente sincronizado com os eventos que regulam os níveis de junções gap presentes na superfície celular (HERVÉ et al., 2007). 
2.3.5 Diferentes padrões de expressão de Cxs em células neoplásicas e não neoplásicas

Já em 1966 se observava alterações na comunicação intercelular por junções gap (CIJG) em células neoplásicas(LOEWENSTEIN, 1966; LOEWENSTEIN; KANNO, 1966). Células que em seu genótipo normal apresentavam determinado nível de conexinas, em genótipos neoplásicos apresentavam diferença significativa tanto em quantidade de conexinas quanto em CIJG (YAMASAKI, 1991). Essas alterações podem ser tanto para mais quanto para menos e o que se acredita hoje, embora ainda sob investigação, é que as conexinas desempenhem papel de supressor de tumor nos estágios inicias do câncer e facilite a invasão e metástase nos estágios mais avançados da doença (CRONIER et al., 2009; NAUS; LAIRD, 2010).

Algumas neoplasias têm mostrado menor expressão de conexinas em relação as suas células originais normais, como é o caso do hepatocarcinoma e os hepatócitos, onde a Cx 32 é menos expressa no tecido neoplásico (YANO et al., 2001; EDWARDS et al., 2008). Glandula mamária normal, lesões hiperplásicas e neoplásicas benignas apresentaram um padrão especifico de expressão de Cx $26 \mathrm{e}$ 43 enquanto que lesões neoplásicas mostraram ter um padrão de Cx 26 superexpresso, porém com localização intracitoplasmática, diferente do que se espera, que é uma marcação em membrana (MESNIL et al., 2005; TORRES et al., 2005; MCLACHLAN et al., 2007). O quadro 1 mostra os padrões de expressão de conexinas vários tipos histológicos normais e neoplásicos. Podemos observar 0 padrão heterogêneo entre os diversos tipos e entre células alteradas e não alteradas em relação à expressão das conexinas (MESNIL et al., 2005). 
Quadro 1 - Estudo da expressão das conexinas em várias amostras de tumores Humanos (linhagem de células e amostras de tecidos) (MESNIL et al., 2005)

\begin{tabular}{|c|c|c|c|}
\hline Orgão/tecido & Patologia & modelo & Expressão de Cx \\
\hline Mama & $\begin{array}{l}\text { Tecido normal } \\
\text { Lesões benignas } \\
\text { Carcinoma ductal } \\
\text { Carcinoma Lobular } \\
\text { Carcinoma invasivo }\end{array}$ & Tecido & $\begin{array}{l}\text { Cx } 26(-) \\
\text { Cx } 43 \text { marcou células mioepiteliais } \\
\text { Cx } 43 \text { marcou células mioepiteliais } \\
\text { Cx } 43 \text { marcou células mioepiteliais } \\
\text { Cx } 26(-) \text { e Cx } 43 \text { (-) } \\
\text { † Cx } 26 \text { (marcação } \\
\text { intracitoplasmática + heterogênea: } \\
\text { 15/27 amostras) }\end{array}$ \\
\hline Fígado & $\begin{array}{l}\text { Mormal } \\
\text { Carcinoma hepatocelular }\end{array}$ & Tecido & $\begin{array}{l}\text { Cx 32(+), Cx 26(+) e Cx 43(-) } \\
\text { Cx26 } \downarrow, / \text { Cx32= citoplasmatica }{ }^{a} \\
\text { Cx43 } \uparrow \text { (citoplasmatica) }\end{array}$ \\
\hline \multirow[t]{4}{*}{ Pulmão } & Normal & Tecido & \multirow{4}{*}{ 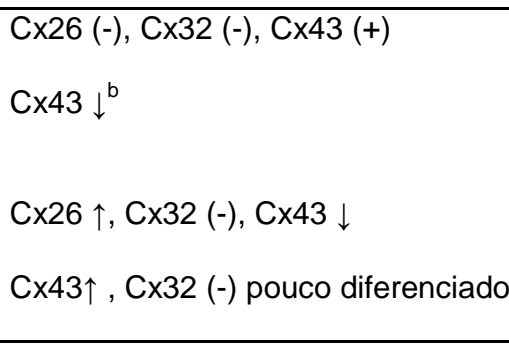 } \\
\hline & Carcinoma & $\begin{array}{l}\text { Linhagem de } \\
\text { células }\end{array}$ & \\
\hline & \multirow{2}{*}{$\begin{array}{l}\text { Carcinoma de células pequenas } \\
\text { Adenocarcinomas e carcinomas } \\
\text { epidermoides }\end{array}$} & Tecido & \\
\hline & & Tecido & \\
\hline \multirow[t]{3}{*}{ Pele } & Normal & Tecido & \multirow{3}{*}{$\begin{array}{l}\text { Cx } 43 \\
\text { Cx } 43 \downarrow^{c} \\
\text { Cx } 43 \downarrow_{\text {e Cx } 26 \downarrow^{d}}\end{array}$} \\
\hline & \multirow{2}{*}{$\begin{array}{l}\text { Carcinoma de células basais e } \\
\text { carcinomas epidermoides } \\
\text { Carcinoma de células basais }\end{array}$} & Tecido & \\
\hline & & Tecido & \\
\hline
\end{tabular}

a - Deficiência no padrão normal de coloração da Cx 32 e localização alterada da marcação da Cx 26 em alguns tumores b - comparada com células epiteliais de pulmão não transformadas

$c$ - pequeno numero de junções gap pequenas e localização citoplasmática da Cx 43.

$d$-heterogeneidade da Imunofluorescência da Cx 26 com impressão de estar com marcação mais pronunciada na periferia dos tumores. 


\subsection{SITUAÇÃO DO ASSUNTO DE PESQUISA}

Os estudos de carcinogênese, comportamento biológico do tumor no hospedeiro, alterações de vias de sinalização de crescimento e diferenciação celular, testes de novos agentes antineoplásicos, quimioprevenção dentre outros são de extrema importância para o desenvolvimento da pesquisa em oncologia. Para isso modelos experimentais são essenciais. Os modelos experimentais que se utilizam de linhagens de células vem ganhando cada vez um maior espaço na pesquisa com a tendência cada vez maios de se utilizar menos os modelos animais.

A utilização de linhagens de células neoplásicas e não neoplásicas como modelos experimentais vem contribuindo muito nas ultimas décadas para o avanço nas pesquisas em medicina e com contribuição especial para o câncer (WARNCRAMER; LAU, 2004; FENTON; HORD, 2006; HEEG et al., 2006). O presente trabalho se utiliza de duas linhagens de células neoplásicas, a B16/BL6 e E9, e uma não transformada, a E10 para avaliação dos efeitos da eletroporação na fisiologia celular, com ênfase na expressão das Cxs.

A eletroporação que começou a ser utilizada como ferramenta de pesquisa nos anos 80 , hoje começa a ser utilizada como principio em novas terapias (LANDSTRÖM et al., 2010; TESTORI et al., 2010). A eletroquimioterapia e a terapia gênica estão entre as principais técnicas que se utilizam do fenômeno (MIR, L. M., 2009; MIKLAVCIC, D. et al., 2010), e hoje trabalhos que tem como objetivo desenvolver modelos que expliquem a fenomenologia envolvida além das possíveis implicações do processo na fisiologia celular vem crescendo (SEL et al., 2007; MLAKAR et al., 2009; JARM et al., 2010; MIKLAVCIC, D et al., 2010). Estes trabalhos tem fundamental importância tanto para que se tenha um melhor controle da eletroporação, quanto para que se utilize do fenômeno com maior segurança (PAVSELJ et al., 2007; SEL et al., 2007). 


\subsubsection{A linhagem de melanoma B16/BL6}

A linhagem B16/BL6 é um subclone da linhagem B16, que foi desenvolvida a partir da de melanomas de camundongos da linhagem C57BL/6. A linhagem original, B16, tem como característica grande diversidade de comportamento biológico e potencial metastático (JOHNSON et al., 1987; ISHIGURO et al., 1996). A sequência para formação do subclone por nós utilizado tem origem na linhagem pouco metastática B16/F1. Essa linhagem foi estabelecida a partir de focos de metástases pulmonares em camundongos onde se administrou células da linhagem B16 por via intravenosa. $\mathrm{Na}$ sequencia se estabeleceu a linhagem altamente metastática B16/F10 a partir de dez sucessivas seleções de focos pulmonares de metástase a partir de injeção intravenosa da linhagem B16/F1. A linhagem B16/BL6, que apresenta maior potencial de metástase entre todas as linhagens B16, é originada a partir de células da linhagem B16/F10 que penetraram na parede da bexiga. As linhagens B16/F10 e B16/BL6 embora sejam muito semelhantes em seu genótipo tem uma diferença marcante. Enquanto a linhagem B16/F10 tem índice de desenvolvimento de metástases pulmonares semelhante a linhagem B16/BL6 quando as células são inoculadas via intravenosa, a linhagem B16/BL6 desenvolve muito mais metástases pulmonares quando as células são inoculadas por outra via, seja ela subcutânea ou intramuscular (ISHIGURO et al., 1996; ITO, A. et al., 2002). Em um experimento onde se inoculou células das duas linhagens no coxim dos camundongos, aqueles que receberam as células da linhagem B16/BL6 apresentaram índice de $87 \%$ de metástases pulmonares enquanto aqueles que receberam injeção com células da linhagem B16/F10 obtiveram índice de metástases pulmonares de 33\% (HART, 1979).

Vários trabalhos no sentido de se tentar identificar diferenças na expressão gênica entre as diferentes linhagens de melanoma B16 já foram desenvolvidos e uma diferença encontrada que é pertinente ao presente trabalho é com relação à expressão da Cx 26 (JOHNSON et al., 1987; NAKAYAMA et al., 1995; ITO, A. et al., 2002). A linhagem B16/BL6 apresentou uma expressão mais elevada de Cx 26 que o tecido hepático, um dos que expressa mais abundantemente essa conexina (ITO, A. et al., 2002). Outra diferença significativa entre a linhagem B16/BL6 e as demais de origem B16, é que ela é capaz de formar CIJG com células endoteliais, através de junções gap heterólogas (ITO, A et al., 2000). 


\subsubsection{As linhagens de células de pulmão E9 e E10}

Desde o fim da década de 70 várias dezenas de linhagens de células de origem pulmonar têm sido estabelecidas tanto de tecidos pulmonares normais quanto a partir de neoplasias de pulmão espontâneas ou induzidas por carcinógenos químicos, virais ou transgenes oncogênicos (MALKINSON et al., 1997). As linhagens foram sendo estabelecidas para que se pudesse ter modelos experimentais confiáveis para se estudar alterações na biologia das células do pulmão ou mesmo o comportamento das neoplasias pulmonares (MALKINSON et al., 1997; SUN et al., 2003). Um dos grandes benefícios de se ter uma linhagem neoplásica e uma não neoplásica que em principio é de onde a transformada se originou é a possibilidade de se poder comparar diretamente as características de uma com as de outra e desta forma ter uma compreensão mais precisa do processo de carcinogênese em suas vária etapas (SUN et al., 2003).

A origem das linhagens de células E9 e E10 estão na linhagem NAL-1A. Esta linhagem foi estabelecida a partir de células de pulmão de camundongos BALB/c que foram colocadas em cultura. As células daí originadas foram classificadas como epiteliais por apresentarem características que indicavam essa origem, como marcação imunoistoquímica para citoqueratina e marcação negativa para vimentina. A linhagem E10 é não neoplásica e apresenta semelhança na morfologia e em muitas outras propriedades com a linhagem NAL-1A. O crescimento das células é isolado até que elas atinjam confluência. Quando elas começam a crescer em confluência as células tornam-se menores, embora seu tamanho dependa do número de passagens. Quanto menor o numero de passagens maiores são as células e mais lentamente elas crescem (MALKINSON et al., 1997). As figuras 5 E 6 mostram o padrão de crescimento das células da linhagem E10. 


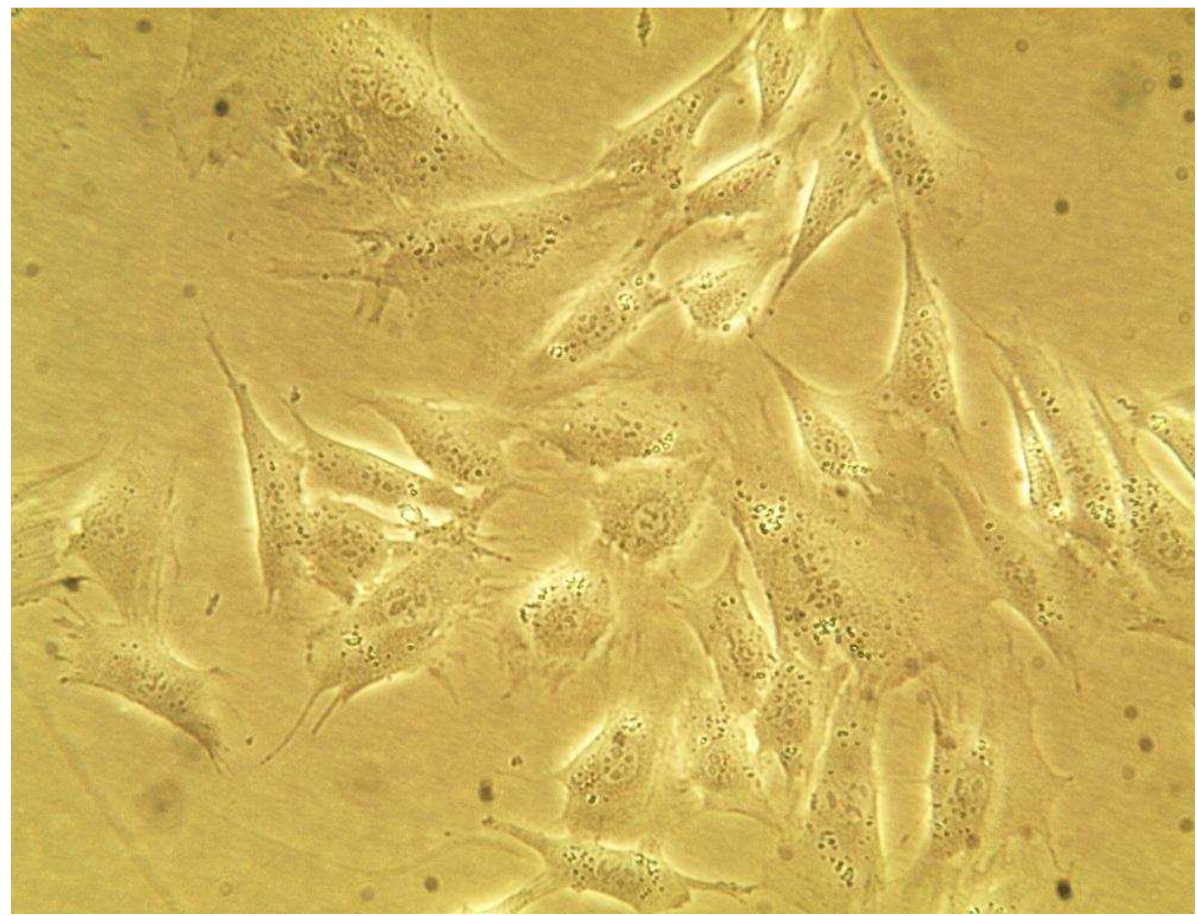

Figura 5 - Padrão de crescimento isolado das células da linhagem E10 (objetiva 40x).

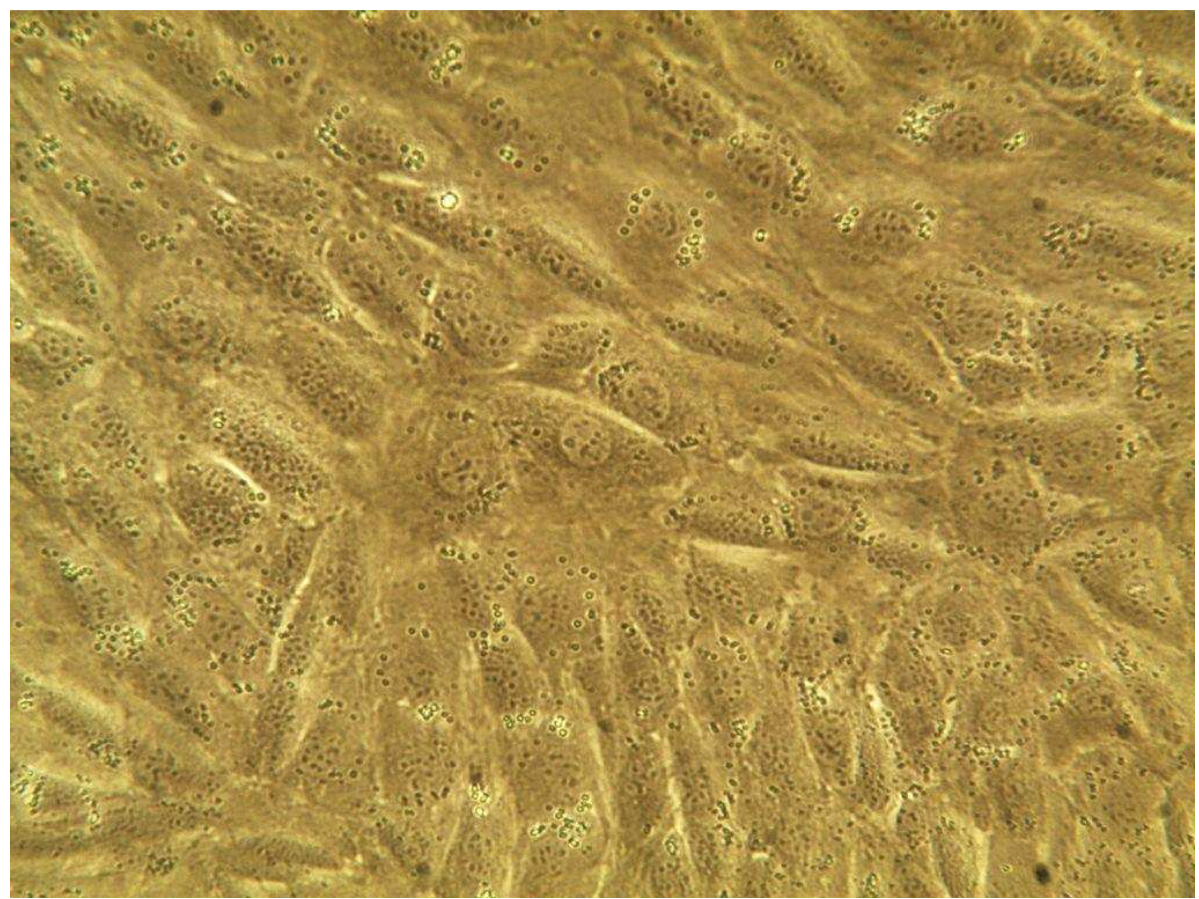

Figura 6 - Padrão de crescimento das células da linhagem E10 já em confluência (objetiva 40x). 
A linhagem de células E9 é uma variante neoplásica. Células da linhagem NAL-1A resistentes ao efeito de inibição do crescimento pela dexametasona foram clonadas e caracterizadas e deram origem a algumas linhagens neoplásicas entre elas a E9. AS células da linhagem E9 ainda são capazes de formar neoplasias em camundongos da linhagem BALB/C com estrutura similar a outras neoplasias epiteliais induzidas quimicamente. Diferentemente da linhagem E10, o padrão de crescimento da linhagem E9 ocorre em ilhas ou grupos celulares. Outra diferença entre as linhagens em relação a morfologia é que E10 apresenta um plano de crescimento celular, uma vez que apresenta inibição do crescimento por contato enquanto E9 pela perda dessa inibição pode apresentar um amontoado de células em seu crescimento (MALKINSON et al., 1997). A figura 7 mostra o padrão de crescimento das células da linhagem E9.

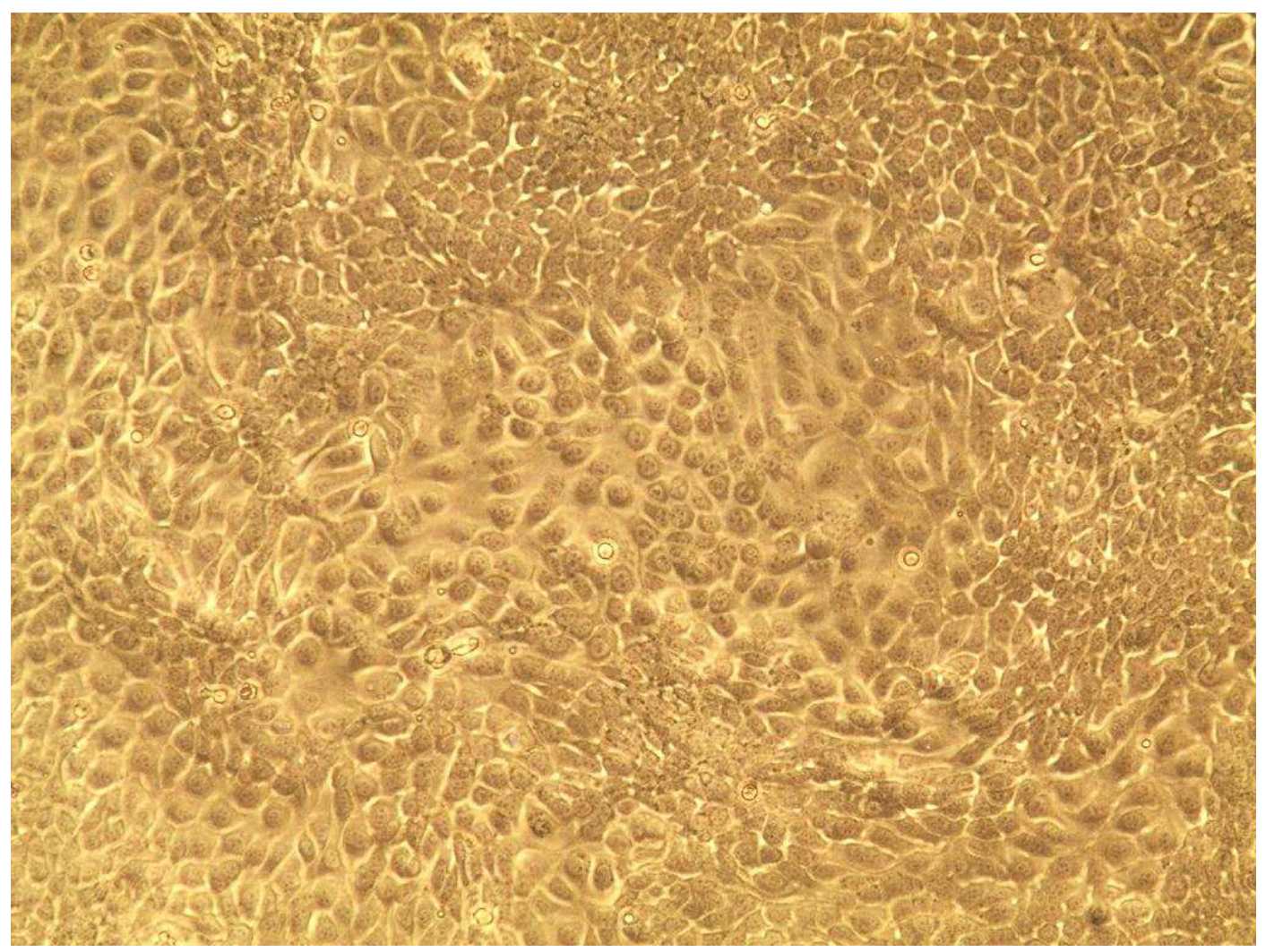

Figura 7 - Padrão de crescimento das células da linhagem E9 já em confluência. As células já se apresentam em amontoados em virtude de não apresentarem inibição por contato (200x). 


\subsubsection{As conexinas nas linhagens de células E9 e E10.}

As células da linhagem E10 se apresentam altamente acopladas por junções gap através da técnica de microinjeção com a coloração de Lucifer Yellow. A difusão do corante através das células se apresentou intensa, ao contrário das células da linhagem E9. Como as junções gap tem como unidades formadoras as conexinas, isso indica que ou elas não estão sendo expressas ou não estão formando as junções gap. Nessa ultima hipótese elas podem estar apresentando localização subcelular. A técnica de imunoblloting verificou a existência da $C x 43$ na linhagem E10, mas não as Cxs 32 e 26 (MALKINSON et al., 1997).

Experimentos de imunofluorescência já detectaram a existência da Cx 43 na linhagem de células E9, e essa marcação pode estar relacionada com o potencial metastático da linhagem. Nesse mesmo experimento foram inoculadas no subcutâneo células da linhagem E9 em comundongos BALB/c, que posteriormente apresentaram não só o crescimento no local da aplicação como o aparecimento de metástases em vários órgãos o que de acordo com a literatura é coerente, uma vez que as conexinas podem estar relacionadas com a progressão tumoral e potencial metastático uma vez as células apresentando um padrão de crescimento independente. A figura 8 apresenta a marcação por imunofluorescência para Cx 43 em células da linhagem E9.

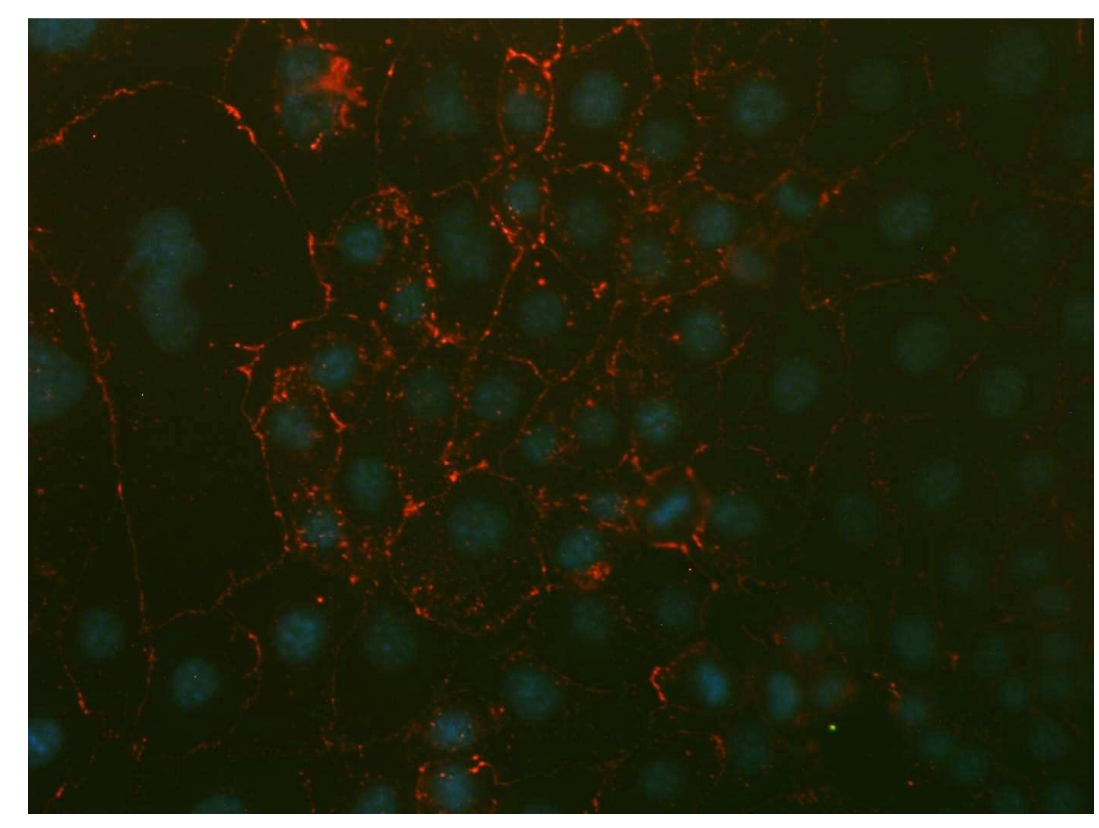

Figura 8 - Imunomarcação em membrana pela técnica de imunofluorescência da Cx 43 em células da linhagem E9. (objetiva 10x) 


\subsubsection{Eletroporação in vitro de células aderidas}

O fenômeno de eletroporação atualmente é amplamente utilizado nos modelos experimentais para o desenvolvimento de terapia gênica, novas drogas, estudos de biologia celular, experimentos de eletroquimioterapia dentre outros (LEBAR et al., 2002; CUKJATI et al., 2007; PAVLIN et al., 2007). Em sua maioria as células a serem eletroporadas se encontram em suspensão, e isso ocorre devido à facilidade de se promover a eletroporação nessa condição (RAPTIS; FIRTH, 1990). A figura 9 mostra um eletrodo para realização de eletroporação de células em suspensão.
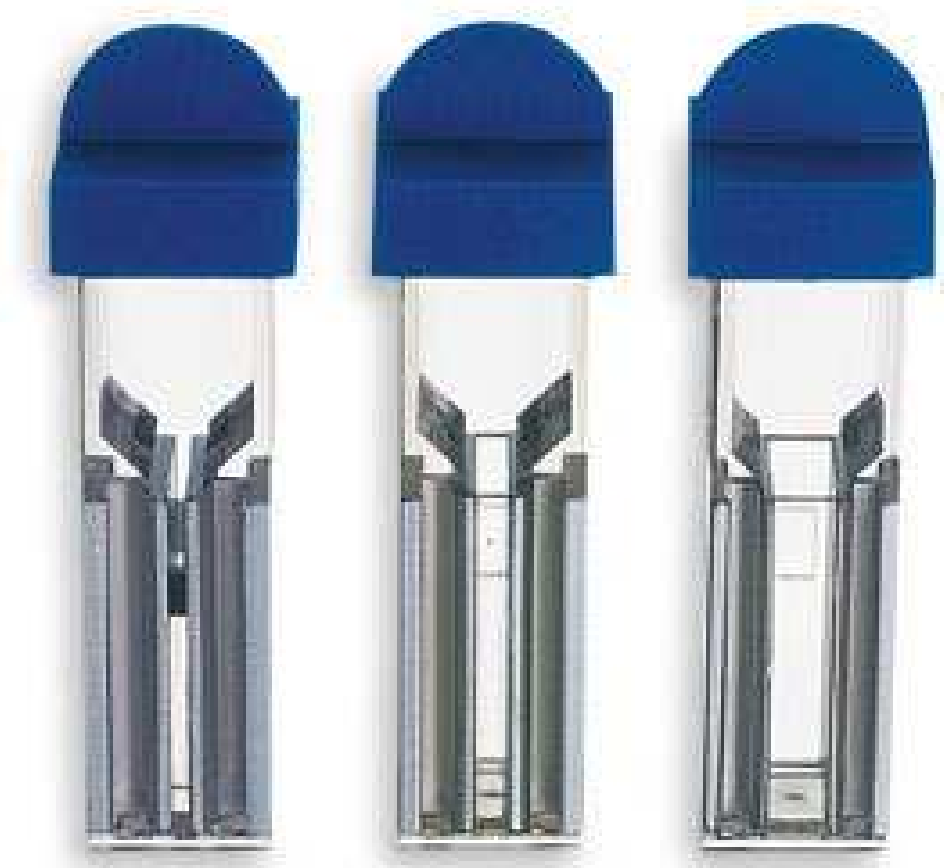

Figura 9 - Eletrodo utilizado para realização de eletroporação de células em suspensão. Podemos reparar que a distância entre as placas dos diferentes eletrodos são diferentes - que proporciona diferentes aplicações de campo elétrico. (fonte: http://www.eppendorf.com/script/binres.php?RID=99821)

A eletroporação de células plaqueadas é um procedimento utilizado somente quando o estudo em questão necessita de células aderidas em placas devido a interferência que o descolamento das células poderá vir a promover nos estudos em questão (RAPTIS; FIRTH, 1990). Em um experimento de transfecção genica 
realizado na década de 90 foi observado uma diferença marcante entre a eficiência da eletroporação entre células em suspensão e células aderidas em placa (ZHENG; CHANG, 1991).

A expressão das conexinas pode sofrer interferência por uma série de fatores, entre eles pelo descolamento das células em modelos experimentais in vitro. $\mathrm{O}$ descolamento das células pode promover a internalização para degradação das junções gap em conexossomos, e dessa maneira aumentar o turnover das conexinas (SEGRETAIN; FALK, 2004; HERVÉ et al., 2007). Outro fator que pode interferir na expressão das conexinas é o grau de confluência das células plaqueadas. Quanto menor a confluência, podemos ter uma menor expressão das conexinas, logo os experimentos são realizados com uma confluência mínima aproximada de $80 \%$ para que se minimize essa interferência nos experimentos.

Os experimentos com eletroporação realizados in vitro em células aderidas utilizam eletrodos específicos, que podem ser de placas paralelas perpendiculares ao plano das células ou com placas paralelas dispostas também paralelamente a linha de crescimento (ZHENG; CHANG, 1991). A figura 10 mostra o esquema de um eletrodo de placas paralelas dispostas paralelamente a linha das células.

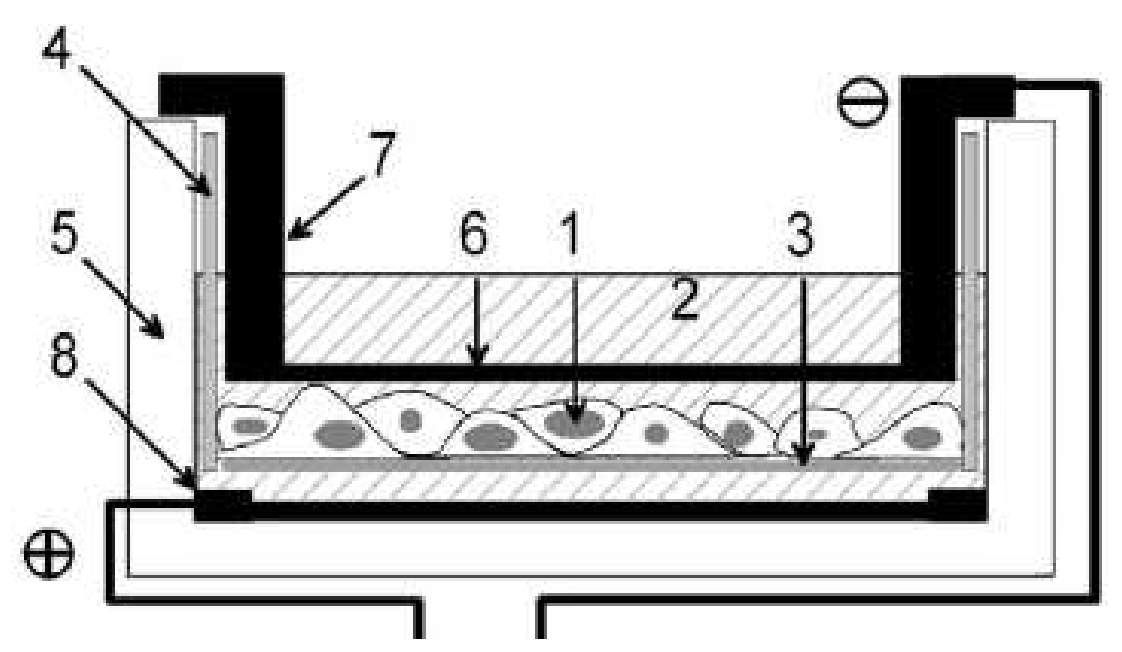

Figura 10 - Esquema de ilustração de um sistema experimental usado para realizar eletroporação para transfecção de células aderidas em placa. (1) monocamada de células; (2)Meio de cultura; (3) Superfície de aderência da placa para as células; (4) câmara de eletroporação; (5) Camara de isolamento externa; (6 e 8) eletrodos (ZHENG; CHANG, 1991). 
2.4.4 Interferência do fenômeno de eletroporação na expressão gênica

O fenômeno de eletroporação vem sendo utilizado como principio em novas modalidades de tratamento (LARKIN et al., 2007; HELLER, L.; HELLER, 2010; MIKLAVCIC, D et al., 2010) e o estudo dos seus efeitos na expressão gênica das células submetidas à eletroporação por si só já demonstrou potencial para promover parada no ciclo celular e apoptose dependente ou indepentente da via de p53 (LEPIK et al., 2003), além de promover aumento dos genes da família HSPA, envolvidos no estresse celular, e diminuição da expressão de genes envolvidos na síntese proteica (MLAKAR et al., 2009). Especificamente no caso das conexinas, por se tratarem de proteínas de membrana formadoras das junções gap, o fato das células estarem aderidas ou não (HERVÉ et al., 2007) e possivelmente perturbações e alterações na membrana citoplasmática podem interferir na meia vida e, por conseguinte no perfil de expressão dessas proteínas (HERVÉ et al., 2007). O fenômeno de eletroporação promove a formação de poros na membrana após exposição a um campo elétrico específico (KANDUSER et al., 2006; SPUGNINI et al., 2007). Essa perturbação poderia então desencadear alterações no perfil de expressão de conexinas. 


\section{OBJETIVOS}

\subsection{OBJETIVO GERAL}

Esta tese tem como objetivo geral avaliar se o fenômeno de eletroporação pode interferir sobre a expressão em genes da família das conexinas.

\subsection{OBJETIVOS ESPECÍFICOS}

- Familiarizar-se com a eletroporação aplicada em organismos vivos através técnica de eletroquimioterapia;

- Padronizar protocolo de eletroporação in vitro em células aderidas;

- Avaliar a interferência da eletroporação sobre a expressão do gene que codifica para a Cx 26 na linhagem de melanoma B16/BL6 através das técnicas de imunofluorescência, western blot e PCR em tempo real;

- Avaliar a interferência da eletroporação sobre a expressão do gene que codifica para a Cx 43 nas linhagens de pulmão E10 (não neoplásica) e E9 (neoplásica) através das técnicas de imunofluorescência, western blot e PCR em tempo real;

- Avaliar possíveis diferenças entre os comportamentos das células neoplásicas e não neoplásicas frente a o fenômeno de eletroporação. 


\section{MATERIAL E MÉTODOS}

Nos itens desta seção estão contidas as descrições dos matérias e metodologias utilizadas neste trabalho.

4.1 Estudos in vivo com a eletroporação: Experimento com eletroquimioterapia em camundongos

Neste item estão contidos o material e metodologias utilizados nos experimentos in vivo.

\subsubsection{Desenho experimental}

O experimento consistiu em implantar células neoplásicas em camundongos e avaliar o índice de resposta à eletroquimioterapia. Quatro grupos foram estabelecidos: o grupo controle (CT), no qual apenas solução fisiológica era administrada no tumor e as placas do eletrodo eram colocadas em contato com a formação (sem pulsos elétricos), o grupo quimioterapia $(Q)$, onde apenas foi administrado o agente antineoplásico, o grupo eletroporação (EP), onde apenas foi aplicado o protocolo de pulsos da eletroporação utilizado na eletroquimioterapia, e o grupo eletroquimioterapia (EQT), onde eram administrados o agente antineoplásico e imediatamente na sequencia aplicados os pulsos elétricos para promover a eletroporação. A avaliação da resposta levou em consideração os critérios da Organização Mundial de Saúde (OMS), que determina a seguinte classificação: resposta completa $(R C)$, resposta parcial $(R P)$, resposta objetiva $(R O)$ estabilização da doença (ED), progressão da doença (PD). A RC ocorre quando o tumor passa a não ser mais palpável, RP se dá quando há uma diminuição maior que $50 \%$ nos produtos das maiores distâncias perpendiculares mensuráveis na lesão, RO nada mais é que a soma das respostas completa e parcial $(R O=R C+R P), N C$ quando há uma diminuição menor que $50 \%$ e aumento de até $25 \%$ e PD para aumentos maiores que $25 \%$. Um mínimo de quatro semanas foi necessário para classificar as respostas ao tratamento. 


\subsubsection{Camundongos da linhagem C57BI/6}

O modelo experimental escolhido foram os camundongos da linhagem C57/BL6. Eles foram mantidos em condições padrão no Biotério do Departamento de Patologia da Faculdade de Medicina Veterinária e Zootecnia na Universidade de São Paulo (FMVZ-USP), sob um ciclo de 12 horas de luz e 12 horas de escuro, em condições controladas de temperatura $\left(20 \pm 4^{\circ} \mathrm{C}\right.$ ), e de umidade relativa (55 $\pm 10 \%$ ). Os camundongos tinham acesso livre a uma dieta padronizada (NUVILAB-CR1 ${ }^{\circledR}$, Nuvital Nutrientes LTDA) e água $(\mathrm{pH} \pm 7.0)$. Ao todo foram utilizados 87 camundongos, todos com 8 semanas de idade. Os camundongos foram separados em quatro grupos sendo o gropo EQT com 28 animais, o grupo $Q$ com 22 animais, o grupo EP com 19 animais e o grupo CT com 18 animais. O projeto foi aprovado pelo comitê de bioética da FMVZ/USP com o numero de protocolo 1375/2008.

\subsubsection{Linhagem de melanoma B16/F10}

As células de melanoma das linhagens B16/F10 (cedidas pelo Prof ${ }^{\circ}$ Dr. José Alexandre Marzagão Barbuto - Laboratório de Imunologia de TumoresDepartamento de Imunologia-ICB-USP) foram cultivadas em meio RPMI-10 1640, suplementado com penicilina $(50 \mathrm{Ul} / \mathrm{mL})$, streptomicina $(50 \mathrm{mg} / \mathrm{mL})$, e I-glutamina (2mmol/L), com adição de $10 \%$ soro fetal bovino em placas de Petri de $100 \mathrm{~mm}$ sob condições padrão $37^{\circ} \mathrm{C}, 5 \% \mathrm{CO}_{2}$, umidade atmosférica. As células permaneceram em cultura até atingirem confluência nas placas mínima aproximada de $80 \%$, quando foram então preparadas para serem inoculadas nos animais. Foram inoculados com $1,5 \times 10^{5}$ células de melanoma transplantável na região do flanco direito. Para a quantificação das células e determinação da viabilidade, o trypan blue dye exclusion staining (24) foi utilizado. Abaixo na figura 11 imagem da cultura de melanoma. 


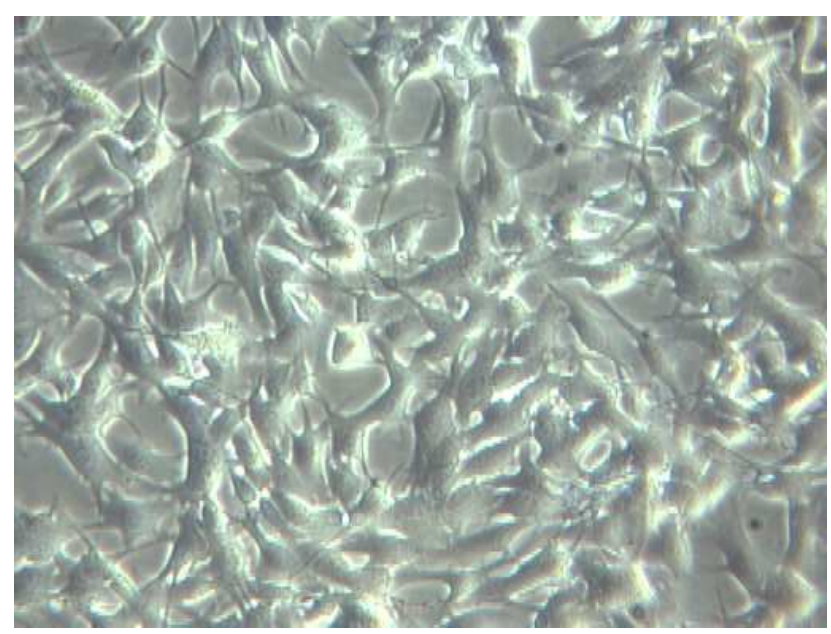

Figura 11 - Foto de cultura de melanoma B16/F10 (Objetiva 10x)

\subsubsection{Procedimento de eletroquimioterapia}

Assim que os nódulos se tornassem palpáveis e atingissem um volume mínimo de $15 \mathrm{~mm}^{3}$ calculados segundo a fórmula $\mathrm{V}=\mathrm{abc} \times \pi / 6$, onde $a, b$ e c são as medidas das dimensões do tumor seguindo três dimensões ortogonais 0 procedimento eletroquimioterápico era realizado. As medidas dos tumores eram realizadas com paquímetro digital. Para tanto, todos os animas eram anestesiados com $100 \mathrm{mg} / \mathrm{kg}$ de quetamina e $10 \mathrm{mg} / \mathrm{kg}$ de xilazina. Assim que atingissem o plano anestésico os animais eram submetidos aos procedimentos descritos anteriormente para os grupos CT, Q, EP e EQT. O agente antineoplásico utilizado foi a bleomicina, na dose de 0,5U/animal e a via de administração foi a intratumoral. A dose de bleomicina administrada nos tumores foi de $0.3 \mathrm{mg}$, diluída em $0.1 \mathrm{ml}$ de solução de $\mathrm{NaCl}$ 0.9\%. O eletrodo utilizado foi de placas paralelas que foi construído no Laboratório de Oncologia Experimental da FMVZ/USP. Ele foi construido sobre um paquímetro para facilitar a medição e posterior cálculo do campo a ser aplicado no momento da terapia. A figura 12 abaixo mostra o eletrodo utilizado no experimento de eletroquimioterapia. 


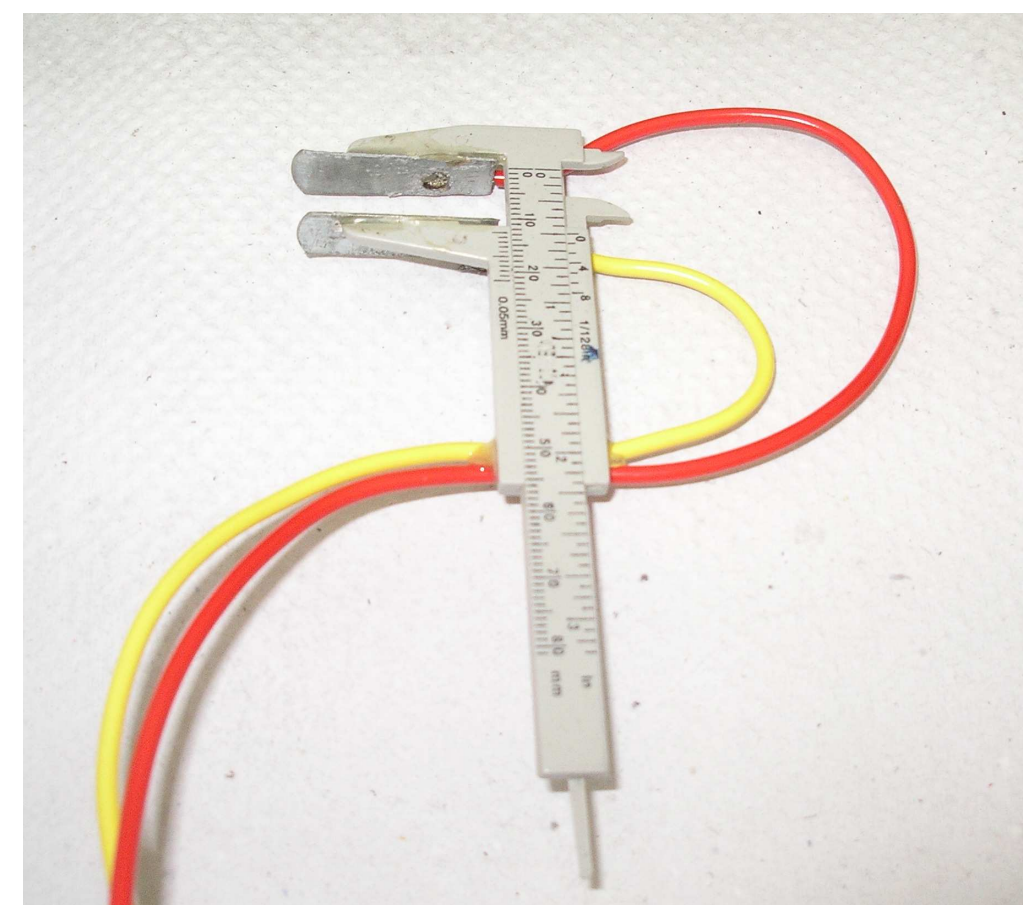

Figura 12 - Foto do eletrodo utilizado no experimento de eletroquimioterapia.

O padrão de pulsos utilizados no experimento de eletroquimioterapia foi o mesmo estabelecido para procedimentos em humanos, com 8 pulsos de $100 \mu \mathrm{s}$ de duração, $1300 \mathrm{~V} / \mathrm{cm}$ de amplitude e $1 \mathrm{~Hz}$ de frequência (CEMAZAR et al., 2008). O dispositivo utilizado para realização das sessões de eletroquimioterapia foi um BTX ECM $830^{\circledR}$. 


\subsection{Estudos in vitro com a linhagem de melanoma B16/BL6}

A proposta dos estudos in vitro serem desenvolvidos após estudos in vivo era que a sequencia da pesquisa tivesse também o respaldo das observações do fenômeno de eletroporação desenvolvido diretamente nos animais e assim trouxesse informações macroscópicas do seu efeito em um organismos vivo. Como a eletroporação hoje é amplamente utilizada como ferramenta em tratamentos essas observações colaboraram com o desenvolvimento da pesquisa nos possibilitando sugerir alguns direcionamentos da pesquisa baseados nas observações in vivo.

\subsubsection{Cultivo de células da linhagem B16/BL6}

As células de melanoma da linhagem B16/BL6 (fornecidas pelo Profo ${ }^{\circ}$. Hiroshi Yamasaki - School of Science, Kwansei Gakuin University, Uegahara, Nishinomiya, Japão) foram cultivadas em meio RPMI-10 1640, suplementado com penicilina $(50 \mathrm{Ul} / \mathrm{mL})$, streptomicina $(50 \mathrm{mg} / \mathrm{mL})$, e I-glutamina $(2 \mathrm{mmol} / \mathrm{L})$, com adição de $10 \%$ soro fetal bovino em placas de Petri de $100 \mathrm{~mm}$ sob condições padrão $37^{\circ}$ C, $5 \% \quad \mathrm{CO}_{2}$, umidade atmosférica. As células permaneceram em cultura até atingirem confluência mínima aproximada de $80 \%$, quando eram então submetidas à exposição dos pulsos elétricos.

\subsubsection{Padronização do protocolo de eletroporação}

Para determinação do protocolo que apresentasse melhor índice de eletroporação associado com maior viabilidade de células foram realizados diversos procedimentos variando a intensidade do campo elétrico aplicado. Foram mantidos os padrões de duração, intervalo e número dos pulsos elétricos aplicados, já descritos em literatura para eletroporação em eletroquimioterapia. 
4.2.2.1 Construção de eletrodo para realização do procedimento em placas de petri

O cultivo de células para os experimentos relacionados a extração de proteínas e mRNA foram realizados em placas de Petri de $100 \mathrm{~mm}$ o que exigiu a construção de um eletrodo especifico para tal fim. O eletrodo foi construído em PVC e placas metálicas de aço inoxidável. A distancia entre as placas instituída foi de 35mm. A figura 13 abaixo mostra o eletrodo construído no Laboratório de Oncologia Experimental da FMVZ/USP.

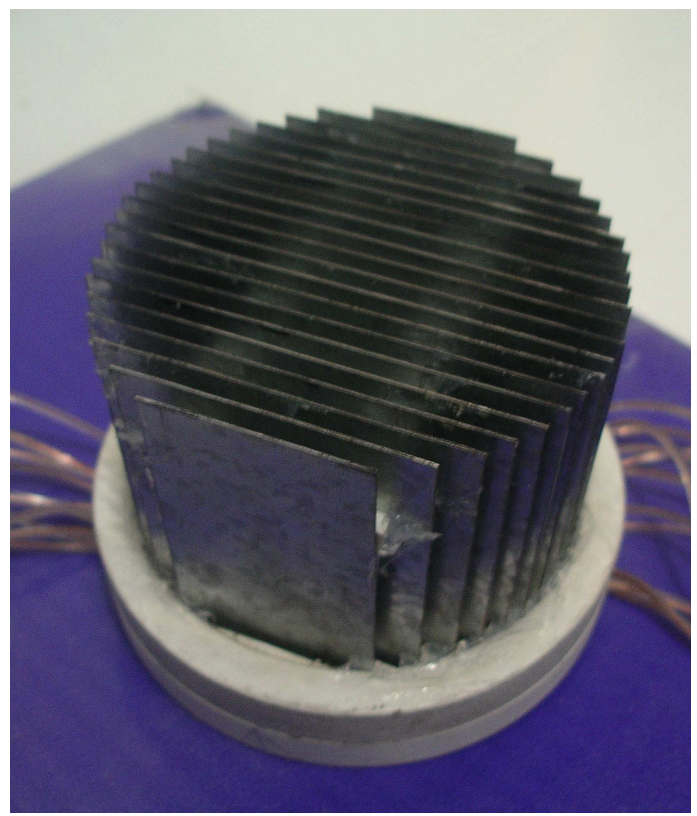

Figura 13 - Eletrodo construído para aplicação do campo elétrico em placas de Petri de 100mm de diâmetro. 


\subsubsection{Avaliação do índice de eletroporação}

Para avaliação da intensidade ótima do campo para eletroporação no modelo experimental proposto foram avaliadas 8 placas de Petri, para cada valor do campo com objetivo de minimizar possíveis erros de avaliação. Os campos aplicados foram de $400 \mathrm{~V} / \mathrm{cm}, 600 \mathrm{~V} / \mathrm{cm}$ e $800 \mathrm{~V} / \mathrm{cm}, 1300 \mathrm{~V} / \mathrm{cm}$. Para avaliação do índice de eletroporação foi solubilizado no meio de cultura brometo de etidio (BrEt) $(0.048 \mu \mathrm{g} / \mathrm{ml}$ de R10). O BrEt não entra em células com membranas íntegras, logo o que se esperara é sua entrada no citoplasma de células que sofreram eletroporação. Para cada intensidade de campo foram criados 4 grupos para avaliação da eletroporação. $\mathrm{O}$ grupo $\mathrm{A}$ recebeu os pulsos elétricos com o meio de cultura e BrEt já solubilizado, o grupo $B$ recebeu com o BrEt já solubilizado sendo apenas colocado o eletrodo sem aplicação dos pulsos, o grupo $C$ recebeu os pulsos e 30 minutos após foi inserido laranja de acridina ( $\mathrm{LaAc}$ ) e BrEt e grupo $\mathrm{D}$ recebeu os pulsos e posteriormente foi feita a avaliação de viabilidade pelo método de azul de trypan. Durante a aplicação dos pulsos. foi mantido apenas um volume mínimo de meio suficiente para formar uma delgada camada sobre as células. Como pode ser observado nas figuras 14 e $15 \mathrm{com}$ o campo de $800 \mathrm{~V} / \mathrm{cm}$ a eletroporação se mostrou mais eficiente em relação ao campo de $600 \mathrm{~V} / \mathrm{cm}$. Com o campo de 1300 $\mathrm{V} / \mathrm{m}$ houve índice maior de morte celular em relação ao campo de $800 \mathrm{~V} / \mathrm{cm}$. O campo de $400 \mathrm{~V} / \mathrm{cm}$ obteve resultado semelhante ao grupo controle com o campo zero, praticamente sem fluorescência. As figuras 16 e 17 evidenciam isso. 


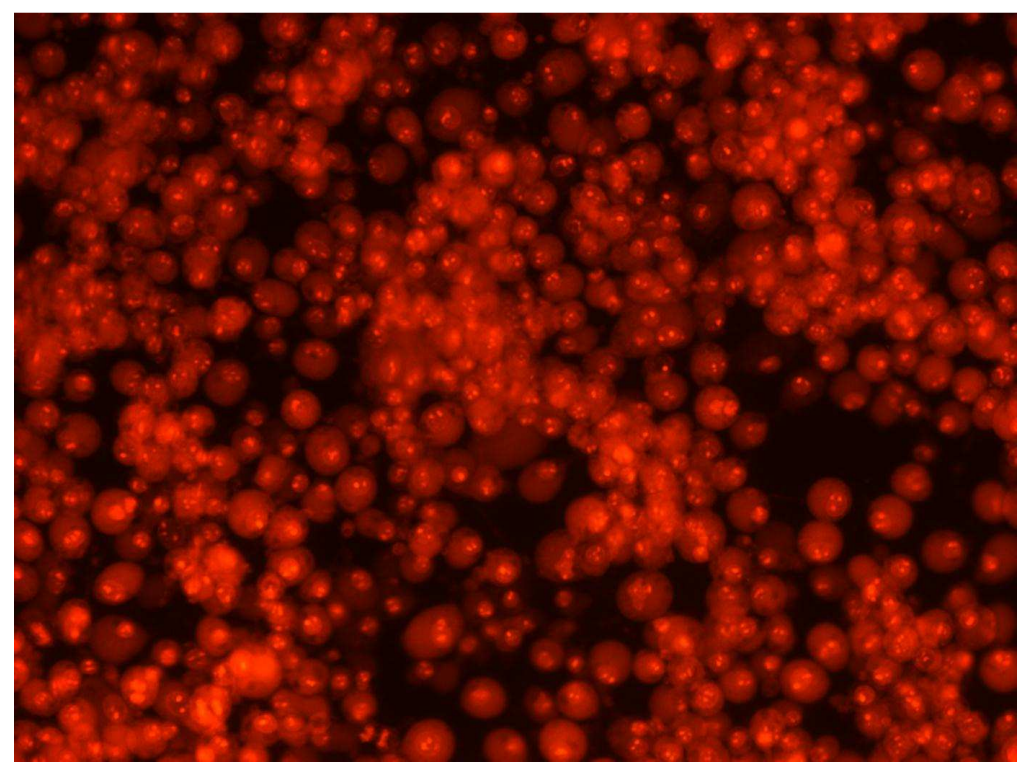

Figura 14 - Fotomicrografia de células eletroporadas com BrEt em meio R10 . O campo foi de $800 \mathrm{~V} / \mathrm{cm}$ (Objetiva 10x)

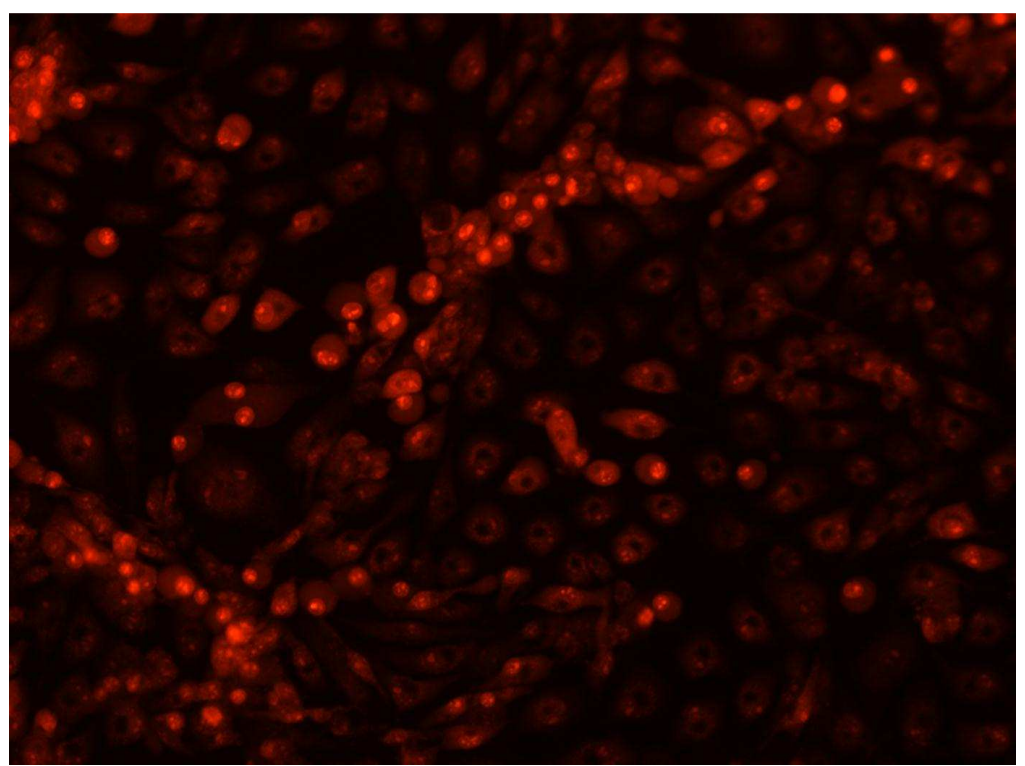

Figura 15 - Fotomicrografia de células eletroporadas com BrEt em meio R10. O campo foi de 600V/cm (Objetiva 10x). 


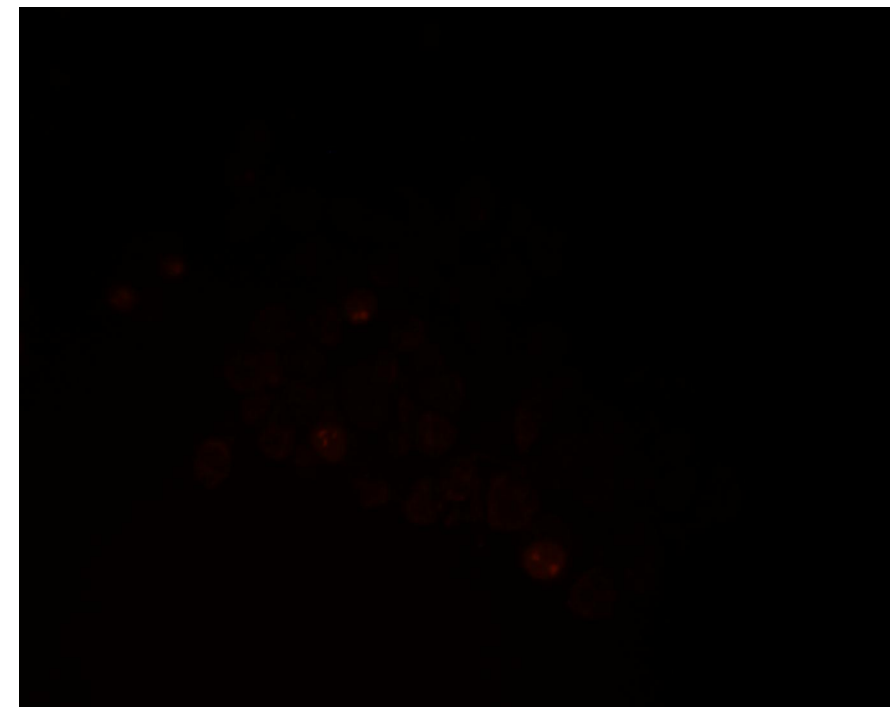

Figura 16 - Fotomicrografia do grupo do campo elétrico de 400V/cm. Nota-se quase nenhuma fluorescência semelhante ao grupo controle negativo. (Objetiva $10 \mathrm{x})$

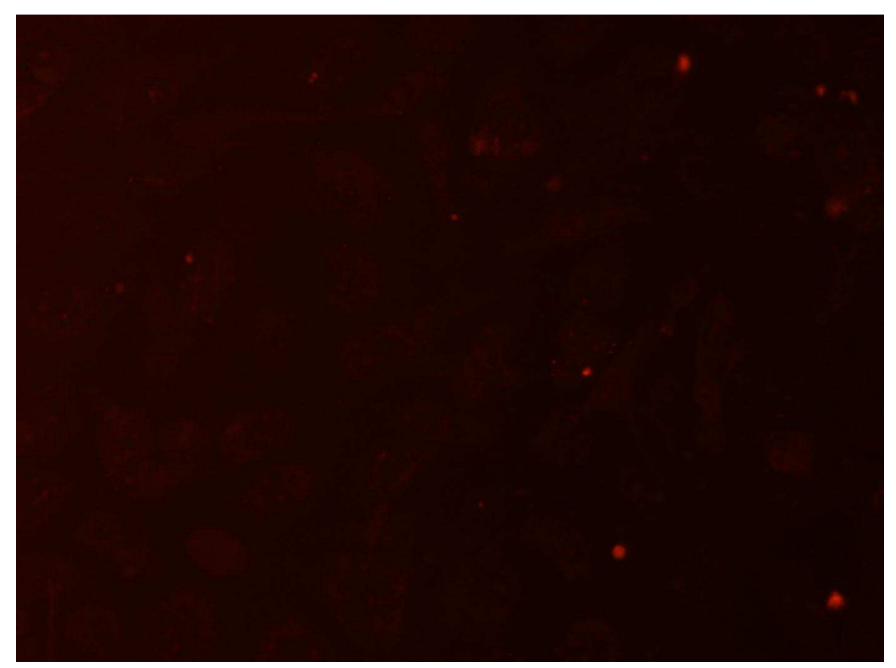

Figura 17 - Fotomicrografia do grupo controle negativo (sem aplicação de campo elétrico). Resultado semelhante ao grupo com campo $400 \mathrm{~V} / \mathrm{cm}$. (Objetiva 10x) 


\subsubsection{Análise de viabilidade celular ao protocolo de eletroporação}

Para avaliação da viabilidade celular e excluir a possibilidade que o processo de eletroporação estivesse matando as células, logo a fluorescência estivesse acontecendo devido a isso e não pela eletroporação foram avaliados os grupos em que o BrEt e LaAc foram adicionados 30 minutos após a aplicação dos pulsos. A grande maioria dos poros se fecha após 10 minutos do processo e resolvemos esperar os 30 minutos para garantir uma melhor reconstituição das membranas. As células também foram avaliadas 1 dia após o procedimento permanecendo com a viabilidade inalterada.

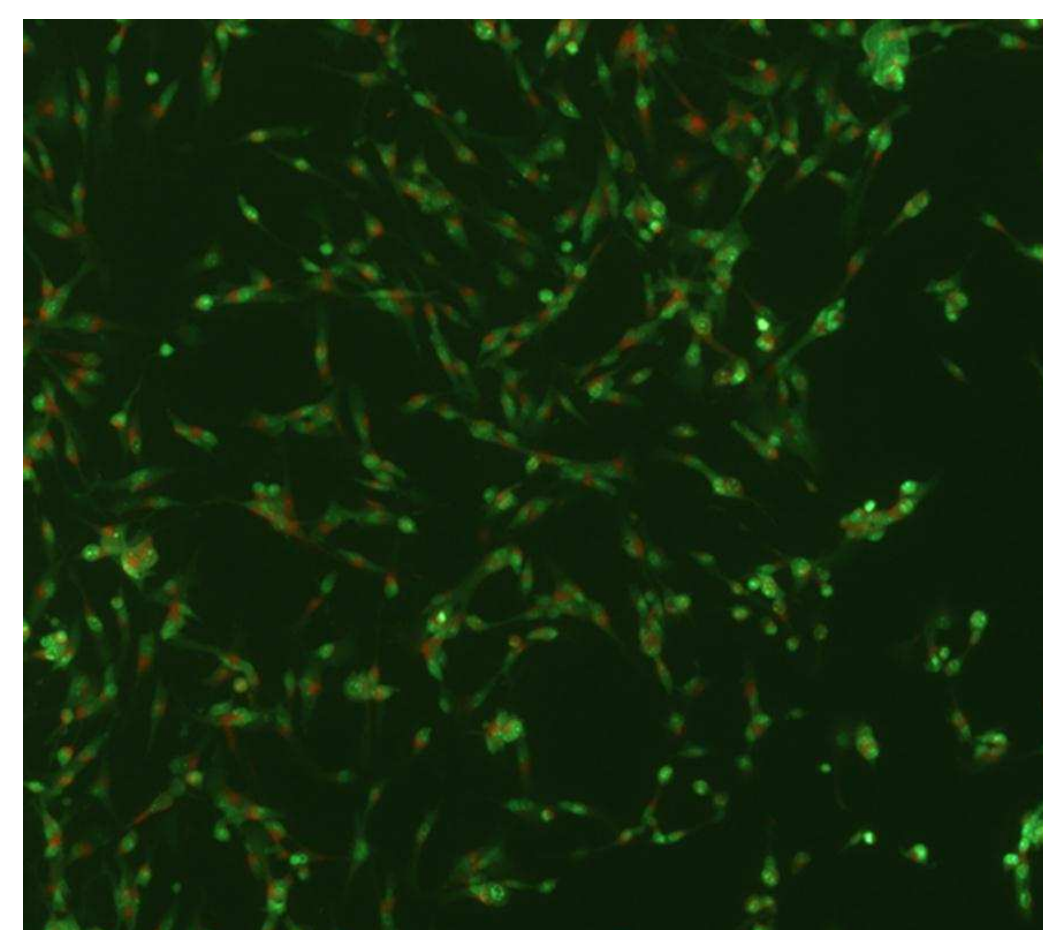

Figura 18 - Fotomicrografia de células que foram submetidas ao protocolo de eletroporação com campo de $800 \mathrm{~V} / \mathrm{cm}$. Trinta minutos após foram inseridos BrEt e LaAc no meio de cultura para avaliação de morte celular (Objetiva 10x). 


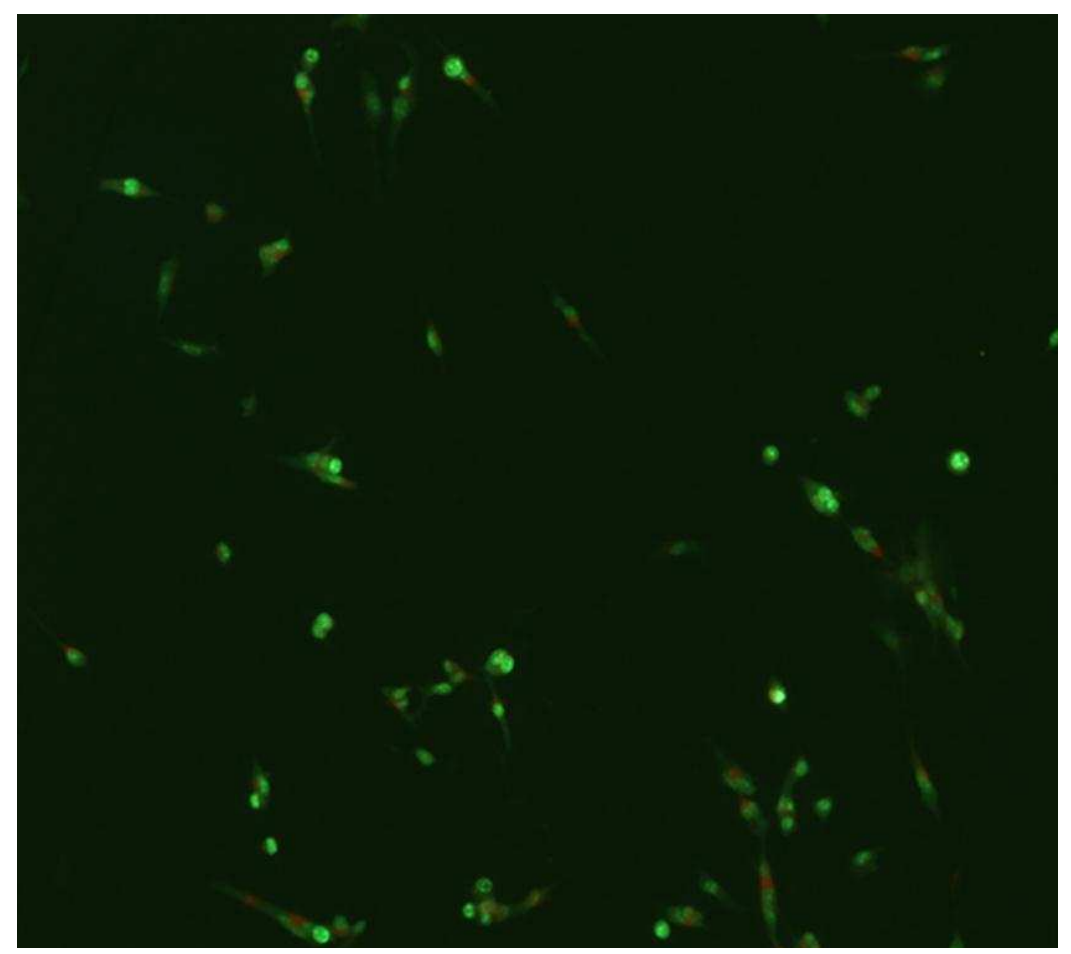

Figura 19 - Fotomicrografia de células que foram submetidas ao protocolo de eletroporação com campo de $1300 \mathrm{~V} / \mathrm{cm}$. Trinta minutos após foram inseridos BrEt e LaAc no meio de cultura para avaliação de morte celular. Percebe-se que a celularidade é bem menor que a do grupo exposto ao campo de $800 \mathrm{~V} / \mathrm{cm}$ (Objetiva 10x). 
Pelo método de avaliação de viabilidade com o corante azul de trypan obtivemos os seguintes resultados mostrados na tabela abaixo:

TABELA 1 Resultados de viabilidade celular pelo método de exclusão com a coloração azul de trypan.

\begin{tabular}{ccccc} 
& $400 \mathrm{~V} / \mathrm{cm}$ & $600 \mathrm{~V} / \mathrm{cm}$ & $800 \mathrm{~V} / \mathrm{cm}$ & $1300 \mathrm{~V} / \mathrm{cm}$ \\
\hline Viabilidade (\%) & 98 & 98 & 92 & 77 \\
\hline
\end{tabular}

\subsubsection{Protocolo de eletroporação utilizado.}

O protocolo de eletroporação adotado de acordo com a eficiência da eletroporação viabilidade celular foi o de 8 pulsos, com amplitude de $800 \mathrm{~V} / \mathrm{cm}$, duração de $100 \mu$ s por pulso e frequência de $1 \mathrm{~Hz}$.

\subsubsection{Imunfluorescência}

Para determinar a localização da Cx 26 e técnica de imunofluorescência foi realizada. $2 \times 10^{5}$ células da linhagem de melanoma B16/BL6 foram plaqueadas em lamínulas de acrílico quadradas de $35 \mathrm{~mm}$ de lado e cultivadas em meio RPMI-10 1640 , suplementado com penicilina $(50 \mathrm{Ul} / \mathrm{mL})$, streptomicina $(50 \mathrm{mg} / \mathrm{mL})$, e Iglutamina $(2 \mathrm{mmol} / \mathrm{L}) \mathrm{com}$ adição de $10 \%$ de soro fetal bovino. Após exposição ao campo elétrico as células foram fixadas em paraformaldeído (PAF) a $2 \%$ por 10 minutos a temperatura ambiente e permeabilizadas em Triton X-100 (Sigma-Aldrich) $0,1 \%$, diluído em leite a $5 \%$, por 30 minutos em temperatura ambiente. As células foram lavadas três vezes em PBS após cada um dos processos (fixação e permeablização). Posteriormente, foram incubadas durante uma noite, a $4^{\circ} \mathrm{C}$, com anticorpos primários contra a cx26 (anticorpo policlonal diluído em Triton X-100 0,1\% em leite a 5\% na concentração final de 1:20; Invitrogen). Três lavagens com PBS por 5 minutos foram realizadas antes da incubação nos anticorpos secundários ligados a um fluorocromo. Em seguida, anticorpos secundários (Alexa 488 anti rabbit 1/100 Invitrogen Molecular Probes( $($ ), feitos em coelho, anti-imunoglobulinas de coelho foram aplicados, diluídos em leite a 5\% com Triton X-100 0,1\%, na concentração de 1:100. Para marcação da actina foi utilizada a toxina faloidina (Alexa 1/100 em Triton 
diluído no leite diretamente do anticorpo secundário). As células distribuídas nas lâminas de vidro foram lavadas com PBS e, em seguida, foram montadas com lamínulas com vectashiel + DAPI (Vector) utilizado como proteção contra a fotodegradação, marcando os núcleos celulares em azul. $O$ material foi imediatamente fotografado em microscópio Nikon E-800, equipado com sistema de fluorescência e fotomicrografia digital.

\subsubsection{Western blot para a conexina 26 da linhagem de células B16/BL6}

Abaixo está descrita a técnica de western blot utilizada nos experimentos in vivo, para a linhagem de melanoma B16/BL6.

\subsubsection{Preparação das amostras}

Assim que as placas de petri apresentaram confluência aproximada de $80 \%$, as células eram expostas ao campo elétrico específico para promover eletroporação reversível. Logo após o procedimento de eletroporação as amostras eram novamente acondicionadas na estufa de $\mathrm{Co}_{2}$ até o tempo pré-determinado para procedimento de extração das proteínas totais. As amostras controle eram submetidas apenas ao peso do eletrodo e as amostras do grupo $t_{0}$ eram submetidas ao processo de extração de proteínas imediatamente após a eletroporação sem serem acondicionadas novamente na estufa de $\mathrm{CO}_{2}$.

\subsubsection{Extração das proteínas}

Para o processo de extração de proteínas, logo após a realização dos procedimentos referentes a cada um dos grupos do experimento as placas foram lavadas 3 vezes com solução de PBS gelado. Esse procedimento foi realizado o mais rápido possível para evitar degradação das proteínas. Após a lavagem, 100 $\mu \mathrm{l}$ de Sample Buffer 2x (SDS 10\%; Tris $\mathrm{HCL} 1 \mathrm{M}, \mathrm{PH}=6,8$; glicerol; $\mathrm{H}_{2} \mathrm{O}$ destilada autoclavada) era adicionado e as placas eram raspadas com auxilio de um cell scrape. O material então era transferido para um tubo de vidro e acondicionado gelado. Na sequencia era tratado por um sonicador 3 vezes na potencia máxima por 
5 segundos evitando-se o aquecimento das amostras. Após este procedimento era adicionado à amostra 100 $\mu \mathrm{l}$ de working solution (Sample Buffer 2x; DTT 1M; PMSF $10 \mathrm{mM} ; \mathrm{H}_{2} \mathrm{O}$ destilada autoclavada) e o mesmo procedimento com o sonicador era realizado. O material então era transferido para um tubo de $1,5 \mathrm{ml}$ e centrifugado a $15000 \mathrm{rpm}$ a $4^{\circ} \mathrm{C}$. O sobrenadante então foi transferido para um novo tubo de $1,5 \mathrm{ml}$ e armazenado a temperatura de $-80^{\circ} \mathrm{C}$ até analise.

\subsubsection{Quantificação das proteínas}

Após extração das proteínas totais, as amostras foram diluídas em $\mathrm{H}_{2} \mathrm{O}$ destilada autoclavada na proporção de 1:5 e a concentração foi estimada através de biofotômetro com o reagente BioRad Protein Assay (Bio-Rad Labs ${ }^{\circledR}$ ). Assim que as concentrações de proteínas totais foram determinadas, uma fração das amostras em um volume final de $40 \mu \mathrm{l}$ foi diluída de maneira que as concentrações finais referentes a cada um dos grupos fiquem homogêneas. A essa solução foi acrescido um volume de $10 \mu \mathrm{l}$ de azul de bromofenol.

\subsubsection{Eletroforese em gel de poliacrilamida}

As proteínas das amostras foram separadas de acordo com o peso molecular através do processo de eletroforese em gel de poliacrilamida na presença de SDS com auxilio de mini cubas verticais (SE 260, ABP Pharmacia), onde $15 \mu \mathrm{l}$ de solução contendo $50 \mu \mathrm{g}$ de proteínas eram desprezados em cada um dos poços do gel. A eletroforese ocorreu sob uma diferença de potencial de $100 \mathrm{~V}$ por aproximadamente 4 horas e imersa em um tampão de corrida (Tris-base $25 \mathrm{mM}$; glicina 192mM; SDS 0,1\%; $\mathrm{H}_{2} \mathrm{O}$ destilada autoclavada). Como marcador de peso molecular foi utilizado $10 \mu \mathrm{l}$ do Kaleidoscópio padrão pré-corado (Bio-Rad Labs ${ }^{\circledR}$ ). $\bigcirc$ tempo de corrida era interrompido assim que a fronte de migração visualizada através do azul de bromofenol chegava a porção final do gel e estava na iminência de cair no tampão de corrida. 


\subsubsection{Eletro-transferência das proteínas}

Após a eletroforese 0 gel foi preparado para 0 processo de eletrotransferência das proteínas e se deu em uma cuba especifica para tal. Nesse processo é preparado um "sanduiche" com as seguintes camadas em sequencia: blotting paper, gel, membrana de PDVF 8,0 x 5,0 cm (Tans-Blot SD cell; Bio-Rad Labs $\left.{ }^{\circledR}\right)$, blotting paper. Todas as camadas devem estar umedecidas com o tampão de transferência (Tris-Base 25mM; glicina 192mM; SDS 0,1\%; metanol 10\%; $\mathrm{H}_{2} \mathrm{O}$ destilada autoclavada). A membrana de PDVF foi previamente hidratada em metanol por 30 minutos. A eletro-transferência ocorreu sob corrente elétrica de $47 \mathrm{~mA}$ por 50 minutos.

\subsubsection{Imunodetecção das proteínas de interesse}

Assim quem o processo de eletro-transferência terminou, iniciou-se 0 processo de imunodetecção das proteínas com 3 lavagens de 5 minutos em TTBS (Tris-Base 20mM; pH 7,6; $\mathrm{NaCl} 150 \mathrm{mM}$; tween 20 a 0,1\%). Após as lavagens a membrana é incubada sob agitação leve em temperatura ambiente por 2 horas em solução de leite desnatado (skin milk) a 5\% diluído em TTBS. No próximo passo as membranas foram incubadas nos anticorpos primários policlonais anti Cx 26 (1:200) em skin milk a $5 \%$ diluídos em TTBS sob agitação leve a $4^{\circ} \mathrm{C}$ overnight. Após a incubação com os anticorpos primários as membranas foram lavadas 3 vezes em TTBS a temperatura ambiente para retirada do excesso de tampão e segui-se a incubação nos anticorpos secundários antirabbit (1:500) conjugados com a peroxidase por 2 horas. A diluição dos anticorpos secundários se deu em skin milk a $5 \%$ diluído em TTBS, da mesma forma que os anticorpos primários. Na sequencia da incubação dos anticorpos secundários as membranas foram lavadas 3 vezes por 10 minutos em TTBS à temperatura ambiente. Procedeu-se então a revelação da membrana em uma solução contendo $\mathrm{DAB}$, Tris $0,05 \mathrm{M}(\mathrm{pH} 7,4)$, Níquel amônio Sulfato e peroxido de hidrogeno a $30 \%$. Quando a revelação já se deu por terminada, evidenciando as bandas de interesse, a reação foi interrompida com $\mathrm{H}_{2} \mathrm{O}$ destilada. A solução de revelação foi preparada minutos antes da reação e mantida em frasco âmbar. 
Após a revelação e secagem as imagens da membrana foram digitalizadas em seguida (Image Máster VDS-CL, Amersham pharmacia biotech ${ }^{\circledR}$ ) para posterior analise densitometrica.

Como controle endógeno a proteína $\beta$ actina foi. Dessa forma a analise densitometrica foi calculada através da porcentagem da proteína analisada em relação à $\beta$ actina. $O$ parâmetro de normalização utilizado para a analise densitometrica foi a banda relativa ao grupo controle.

4.2.4.7 Reação da Polimerase em Cadeia registrada em tempo real (Real Time PCR) para Cx 26 na linhagem de melanoma B16/BL6

A expressão da Cx26 fol verificada através dos níveis de RNAm. Após exposição ao campo elétrico as células foram raspadas das placas de Petri utilizando-se cell srape (Corning) nos respectivos tempos determinados para o estudo. Após a raspagem as células foram colocadas em tubos de plástico e centrifugadas a $1500 \mathrm{rpm} \mathrm{e} 4^{\circ} \mathrm{C}$ por 10 minutos. Depo is da centrifugação o meio de cultura residual foi desprezado e se iniciou a extração do RNA com o kit RNAspin mini (GE Healthcare). Antes do procedimento de extração toda a bancada foi limpa com álcool $70^{\circ}$ preparado com $\mathrm{H}_{2} \mathrm{O}$ preparada com DEPC. Após esse procedimento a bancada foi limpa com solução de RNAse Away (Invitrogen Life Technologies). Após a extração uma alíquota foi removida para verificar a integridade do RNA em gel e para sua quantificação em Biofotômetro (Eppendorf $®$ ). $O$ restante da solução foi armazenada imediatamente a $-80^{\circ} \mathrm{C}$ até a confecção do cDNA. Para a transcrição reversa, $3 \mu \mathrm{g}$ do RNA total foram acrescidos $1 \mu \mathrm{l}$ de dNTP (mix $10 \mathrm{mM}-$ 2,5 mM de cada dNTP) e $1 \mu \mathrm{l}$ de Oligo DT e incubado a $65^{\circ} \mathrm{C}$ por 5 minutos. Em seguida foi adicionado $4 \mu$ l de buffer $5 x$ (superscript III), $2 \mu$ ITT $1 \mathrm{M}$ e $1 \mu$ le RNAse OUT e incubado por 2 minutos a $42^{\circ} \mathrm{C}$. Acrescentou-se $1 \mu \mathrm{l}$ de superscript III, incubando-se por 50 minutos a $42^{\circ} \mathrm{C}$, seguido de incubação por 15 minutos a $70^{\circ} \mathrm{C}$. Ao término da incubação foi acrescentado $1 \mu$ de enzima RNAse $\mathrm{H}$ aos tubos (para retirada dos resíduos de RNA da amostra de cDNA) e incubados a $37^{\circ} \mathrm{C}$ por 20 minutos. O cDNA foi armazenado a $-20^{\circ} \mathrm{C}$ até o moment o da amplificação do cDNA. Todos os reagentes foram adquiridos da Invitrogen Life Technologies ${ }^{\circledR}$. O PCR em 
Tempo Real foi realizado em ABI Prism 7000 Sequence Detection Systems (Applied Biosystems ${ }^{\circledR}$, Foster City, CA) utilizando TaqMan Universal Master Mix (número do item 4304437; Applied Biosystems). primers e as sondas TaqMan para Cx26, Cx43 e 18 s (usado como um controle de limpeza). Os ensaios da Cx26 (Cf02690416_g1) foram adquiridos pela Applied Biosystems®.

Utilizou-se o 18S, como controle de limpeza, sendo adquirido pela Applied Biosystems® (4319413E). O grupo controle foi utilizado com parâmetro de normalização. Para as sondas TaqMan utilizaram-se um corante repórter 5'-6carboxi-fluoresceína (FAM), um corante quencher 3'-não-fluorescente (QNQ) e uma ligação menor groove (MGB). Os primers e sondas foram utilizadas com eficiência de $100 \%$ na concentrações finais de $0,9 \mathrm{mM}$ e $0,25 \mathrm{mM}$, respectivamente. As condições de ciclagem térmica para os ensaios de quantificação do DNA foram estabelecidas de acordo com a ABI Prism 700 Sequence Detection System parâmetros (Applied Biosystems®). A análise dos dados de expressão relativa do gene foi realizada de acordo com o método CT.

A qualidade das amostras de RNA foi determinada por eletroforese em gel de agarose $2 \%$ com coloração para Brometo de Etídio. As bandas $18 \mathrm{~S}$ e $28 \mathrm{~S}$ foram visualizadas sob luz ultravioleta (não mostrado). O RNA total foi então tratado com DNase I (Invitrogen Life Technologies®), antes do processamento. O Oligo DT (1 ml) e dNTPs $(1 \mathrm{ml})$ foram adicionados à amostra de RNA total $(500 \mathrm{mg})$ e incubados a $65^{\circ} \mathrm{C}$ por 5 minutos. Após este procedimento, foram a dicionados à mistura: Buffer 5 x (sobrescrito II, $4 \mu \mathrm{l}$ ); TDT ( $1 \mathrm{ml}, 2 \mu \mathrm{l})$ e RNAse OUT $(1 \mu \mathrm{l})$ e incubado a $42^{\circ} \mathrm{C}$ por 2 minutos. Novamente o sobrescrito II (1 ml) foi adicionado, seguindo uma incubação à $42^{\circ} \mathrm{C}$ por 50 minutos e posteriormente, a incubação foi realizada a $70^{\circ} \mathrm{C}$ por 15 minutos.

Todos os experimentos em PCR tempo real foram realizados pelo menos três vezes. Esta técnica permitiu quantificar a expressão de mRNA do gene da Cx 26 e comparar as mesmas com os níveis de proteínas mensurados pela técnica de western blot e observados pela técnica de Imunofluorescência. 


\subsection{Estudos in vitro com as linhagens de células de pulmão E9 e E10}

As células das linhagens E9 e E10 são neoplásicas e não neoplásicas respectivamente e as metodologias que se seguem foram semelhantes as adotadas na linhagem de células B16/BL6. As particularidades foram descritas em cada item específico.

\subsubsection{Cultivo de células das linhagens E9 e E10}

As células E10 (variante não transformada) e E9 (variante tumoral) foram gentilmente doadas pela Dra. Lucy M. Anderson sob os cuidados de sua técnica Janet Fields do Laboratório de Carcinogênese Comparada do Instituto Nacional do Câncer (Fredericks - EUA). Estas foram mantidas em nitrogênio líquido até sua utilização. O processo de descongelamento consistiu em manter o criotubo congelado em banho-maria à $37^{\circ} \mathrm{C}$ até que o conteúdo descongelasse parcialmente, sendo então rapidamente homogeneizado com dois volumes de meio de cultivo CMRL1066 adicionado de 10\% de soro fetal e glutamina. As células foram então centrifugadas a 1200 RPM por 10 minutos, o sobrenadante descartado e o pellet de células re-suspendido em meio de cultivo. Após resuspendidas as células foram colocadas em garrafas de cultivo adicionando-se $10 \mu \mathrm{l} / \mathrm{ml}$ estreptomicina e $20 \mu \mathrm{l} / \mathrm{ml} \mathrm{L}$ glutamina. As células foram mantidas e em estufa a $37^{\circ} \mathrm{C}$ com atmosfera úmida com $5 \%$ de $\mathrm{CO} 2$. Quando estas atingiram cerca de $80 \%$ de confluência estavam preparadas para a realização dos experimentos.

\subsubsection{Imunofluorescência da conexina 43 nas linhagens E9 e E10}

A Imunofluorescência foi realizada com a mesma metodologia utilizada na linhagem de células B16/BL6, somente diferindo da forma de fixação (metanol por 30 minutos) e dos anticorpos primários e secundários que foram utilizados. Neste caso utilizou-se policlonais anti-Cx43 (anticorpo policlonal diluído em Triton X-100 $0,1 \%$ em leite a $5 \%$ na concentração final de 1:00; Transduction laboratories) e 
anticorpos secundários anti-coelho na concentração de 1:100 (Alexa 488 anti rabbit 1/100 Invitrogen Molecular Probes(C)

\subsubsection{Western blot para a conexina 43 nas linhagens E9 e E10}

A técnica de western blot foi realizada com os mesmo parâmetros descritos para a linhagem B16/BL6, diferindo apenas dos anticorpos primários que no caso dessas linhagens foi anti $\mathrm{C} \times 43$. Outro procedimento realizado para essas linhagens foi $o$ stripping, e este foi necessário pois o controle endógeno utilizado nesse experimento foi a $\beta$-actina, que tem peso molecular semelhante ao da $\mathrm{Cx} 43$.

\subsubsection{Stripping das membranas}

O processo de stripping é o nome utilizado para a técnica de remoção dos anticorpos primários e secundários das membranas de western blot permitindo assim novo procedimento em uma mesma membrana. O procedimento de stripping utilizado no experimento consistiu de primeiramente hidratar as membranas por 10 minutos em álcool metílico $\left(99,9^{\circ}\right)$. Após a hidratação lavar as membranas por 5 minutos em TTBS. Na sequencia incubar as membranas no tampão de stripping (Tris-HCL 62mM, pH6,8; SDS 2\%. 2- $\beta$-mercaptoetanol 100mM) por aproximadamente 30 minutos a temperatura de $60^{\circ} \mathrm{C}$. Depois da incubação bloquear a reação com skin milk a $5 \%$ diluído em TTBS $0,2 \%$. A partir desse processo as membranas novamente estão prontas para o inicio da incubação com os anticorpos primários.

4.3.4 Reação da Polimerase em Cadeia registrada em tempo real (Real Time PCR) para Cx43 nas linhagens E9 e E10

O PCR em tempo real para as linhagens E9 e E10 seguiram o mesmo padrão desenvolvido para linhagem B16/BL6, com a única diferença para os Primers que para CX43 foram concebidos a partir de exons (GenBank XM_543178), em frente 5'CTCATCTACCTGGGCCATGTG 3' e 5' TCGCGCTCCTTCTTCTTCTC 3' primers 
reverse e CF-RG6M2-Cx43, FAM, CCATGCGCACGATGTG. Os ensaios da Cx43 (Cf02690400_g1) foram adquiridos pela Applied Biosystems ${ }^{\circledR}$.

Todos os experimentos em PCR tempo real para as linhagens E9 e E10 foram realizados pelo menos três vezes da mesma forma que na linhagem B16/BL6, permitindo assim quantificar a expressão de mRNA do gene da Cx 43 e comparar as mesmas com os níveis de proteínas mensurados pela técnica de western 


\section{RESULTADOS}

Os resultados de todos os experimentos deste trabalho são apresentados nas seções a seguir.

\subsection{Resultados dos experimentos in vivo}

As seções a seguir apresentam os resultados dos experimentos realizados in vivo.

\subsubsection{Resposta a eletroquimioterapia para melanomas da linhagem B16/BL6} inoculados em camundongos C57/BI6

O grupo que recebeu eletroquimioterapia apresentou eficiência terapêutica satisfatória enquanto nenhum dos outros grupos apresentou resposta. O grupo EQT apresentou 5 tumores (18\%) com ED, 16 tumores (57\%) com RP e 7 tumores com RC (25\%). Com base nestes dados o grupo EQT apresentou um índice de RO de $85 \%$. Neste grupo nenhum tumor apresentou PD. Os 22 tumores do grupo Q, os 19 tumores do grupo EP e os18 tumores do grupo CT não apresentaram resposta a terapia, desta forma todos as tumores apresentaram PD. Estes resultados estão na tabela $\mathrm{X}$ abaixo.

Tabela 2- Tabela de comparação entre as respostas às terapias do experimento.

\begin{tabular}{|c|c|c|c|c|c|}
\hline & \multicolumn{5}{|c|}{ Valores em \% } \\
\hline & PD & ED & RP & RC & RO \\
\hline $\mathrm{EP} / \mathrm{Q} / \mathrm{CT}$ & 100 & 0 & 0 & 0 & 0 \\
\hline EQT & 0 & 18 & 57 & 25 & 82 \\
\hline $\begin{array}{l}\text { EP - eletropora } \\
\text { PD - Progressã } \\
\text { RO - Resposta }\end{array}$ & $\begin{array}{l}\text { oterapi } \\
\text { D - Es } \\
\text { (C) }\end{array}$ & 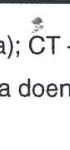 & $\begin{array}{l}T-e l \\
\text { Issão }\end{array}$ & $\begin{array}{l}\text { Erapia. } \\
\text { - Rem }\end{array}$ & npleta; \\
\hline
\end{tabular}

Os efeitos colaterais observados foram contrações musculares no momento da aplicação dos pulsos elétricos, edema local, que se resolveu em todos os casos 
em no máximo 3 dias após a terapia, e necrose nos tumores onde foi aplicada a eletroquimioterapia. A variação do volume apresentada pelos tumores após a terapia durante os 15 dias de acompanhamento demonstrou diferença significante $(p<0.05)$ entre o grupo EQT e todos os demais grupos. Não houve diferença significante $(p<0.05)$ entre os grupos EP, Q e CT.As figuras 20, 21, 22, 23, 24, 25 e 26abaixo mostram a evolução de um dos animais que obtiveram resposta completa frente a eletroquimioterapia.

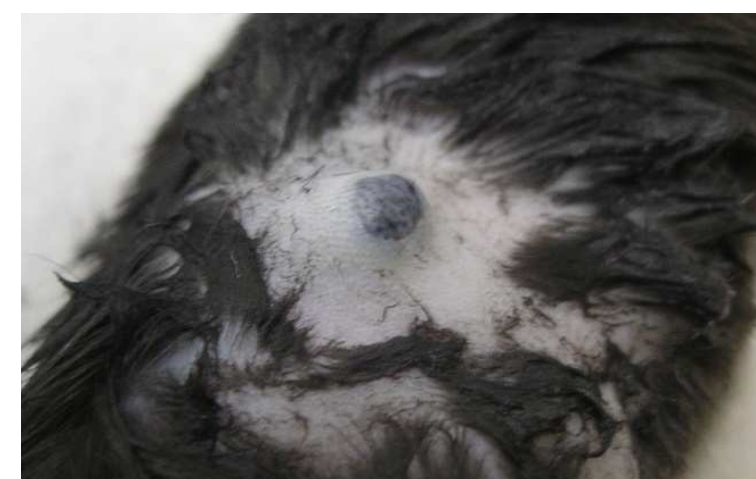

Figura 20 -Eletroquimioterapia em camundongo com melanoma implantado - antes do tratamento

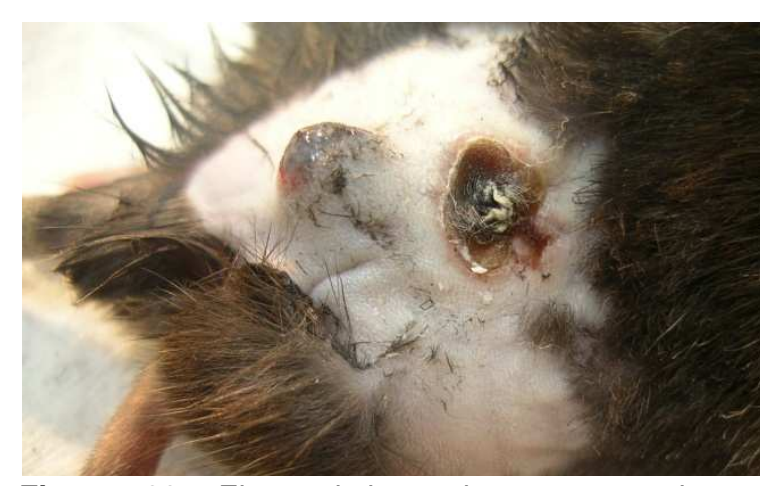

Figura 22 -Eletroquimioterapia em camundongo com melanoma implantado - 7 dias após 0 tratamento $2^{\circ}$ tumor cresce à esquerda do tratado.

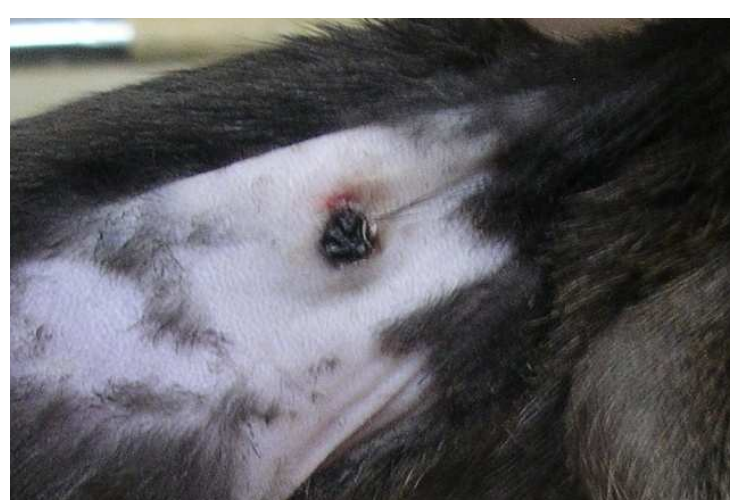

Figura 21 -Eletroquimioterapia em camundongo com melanoma implantado - 1 dia após 0 tratamento.

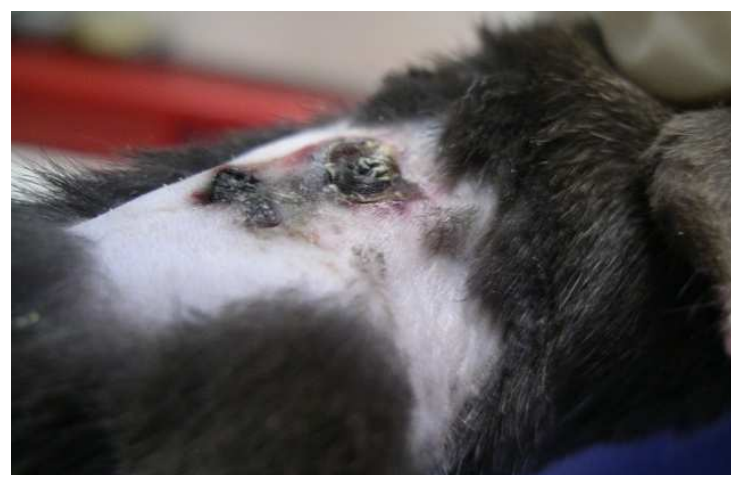

Figura 23 -Eletroquimioterapia em camundongo com melanoma implantado - 1 dia após do segundo tumor ser tratado.

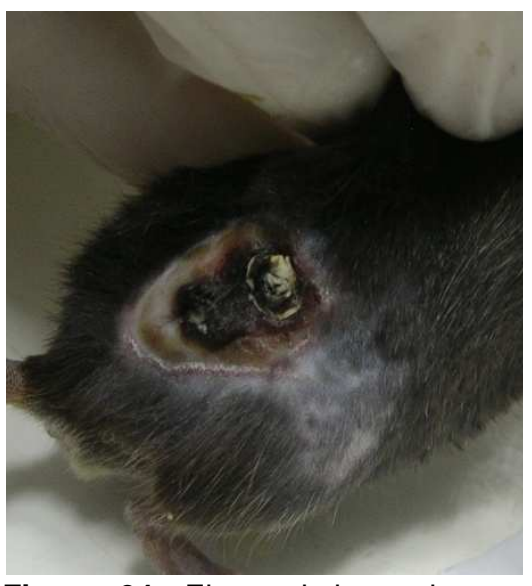

Figura 24 -Eletroquimioterapia em camundongo com melanoma implantado - 12 dias após $1^{\mathrm{a}}$ seção

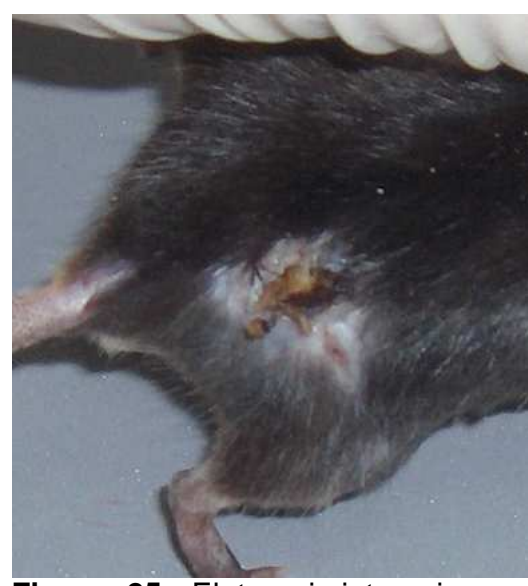

Figura 25 -Eletroquimioterapia em camundongo com melanoma implantado - 20 dias após $1^{\mathrm{a}}$ seção.

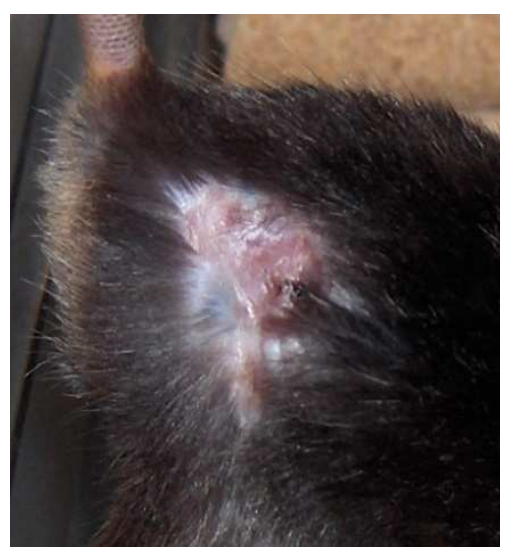

Figura 26 -Eletroquimioterapia em camundongo com melanoma implantado - 27 dias após 1a seção. 
Nesse experimento foi feito acompanhamento diário da evolução da resposta ao tratamento eletroquimioterápico. As diferenças entre os grupos CT, EP e QUIMIOforam significativasem relação ao grupo EQT e estão evidenciadas na figura 27 abaixo.

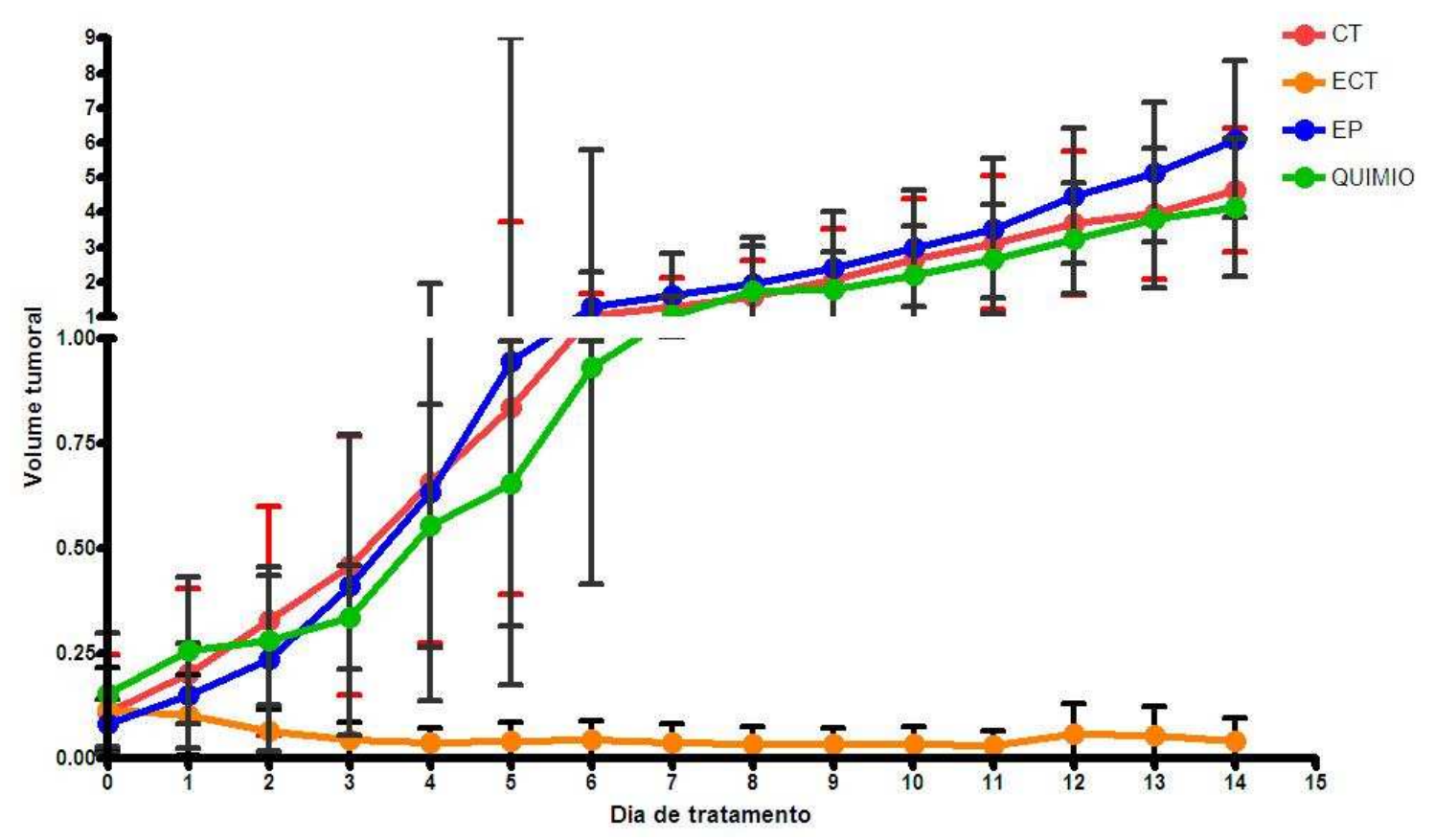

Figura 27 -Gráfico comparativo diário do volume tumoral entre os grupos - os tumores foram tratados no dia 0 e seu volume medido diariamente por quinze dias para avaliação da resposta à terapia.

\subsection{Resultados dos experimentos in vitro}

Este seção se destina a apresentação dos resultados dos experimentos in vitro. As seções subsequentes são específicas para cada uma técnicas e linhagens utilizadas nos modelos experimentais.

5.2.1 Resultados dos experimentos envolvendo a linhagem de melanoma B16/BL6

Agora serão apresentados os resultados dos experimentos para a linhagem B16/BL6 de todas as técnicas empregadas no estudo. 


\subsubsection{Imunofluorescência para Cx 26}

A titulação utilizada para esta técnica foi de 1:20 de anticorpo primário contra Cx 26, o que representa uma grande quantitade de anticorpo para marcação. Mesmo com essa alta titulação observamos apenas uma leve marcação nos diferentes grupos que representam os diferentes tempos após eletroporação. As marcações verde representam as marcações da Cx26, em vermelho representam a $\beta$-actina e a em azul o núcleo. Nesta técnica foram avaliadas as marcações da Cx26 nos diferentes tempos. $O$ que podemos observar é que a localização da Cx26 nessa linhagem é subcelular e não em membranas onde formariam junções GAP. As figuras 28 e 29mostram as marcações das Cx26 no grupo controle e tempo 3 horas após a eletroporação.

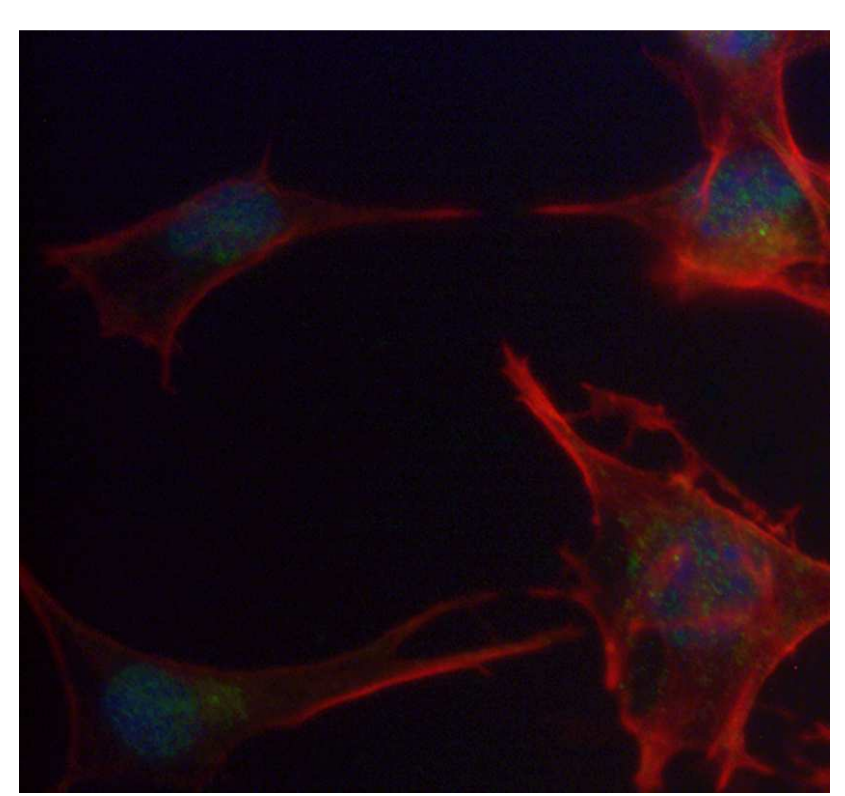

Figura 28 - A figura 28 apresenta a marcação para Cx26 (em verde) no grupo controle. A marcação em vermelho representa a marcação da $\beta$-actina e a azul representa o núcleo. A imagem apresenta marcação intracitoplasmática. (objetiva 40x)

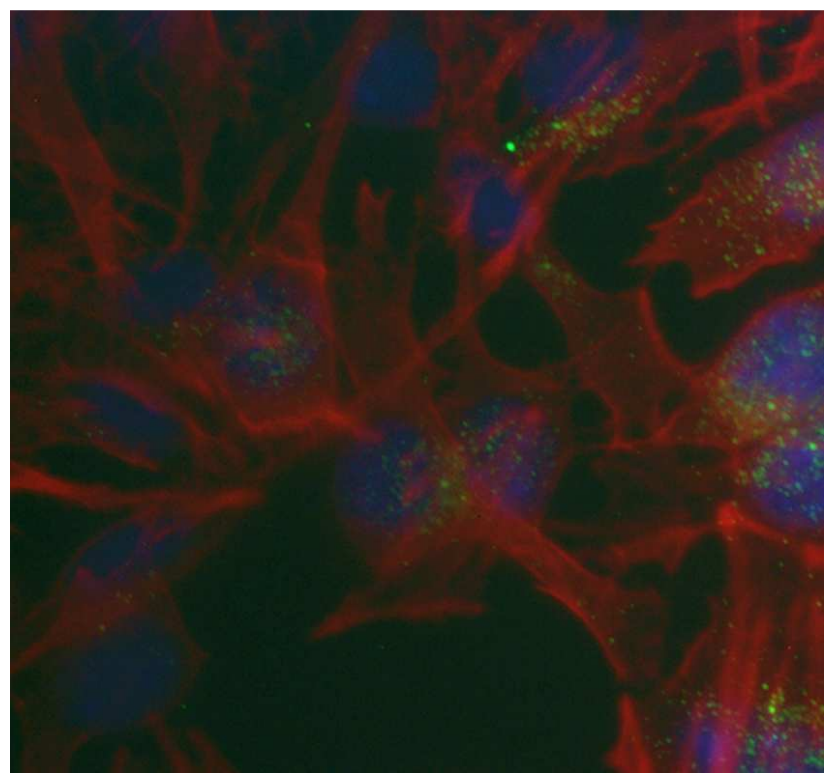

Figura 29 - A figura 29 apresenta a marcação para Cx26 (em verde) no grupo $t_{3}$ (tempo 3 horas após eletroporação). A marcação em vermelho representa a marcação da $\beta$-actina e a azul representa o núcleo. A imagem apresenta marcação intracitoplasmática.(objetiva 40x) 


\subsubsection{Western blot para Cx 26 na linhagem B16/BL6}

As seções subsequentes apresentam todos os resultados referentes à técnica de western blotpara Cx 26 na linhagem B16/BL6.

\subsection{Quantificação de proteínas totais}

O desenvolvimento da técnica de western blotexige que as amostras de proteínas sejam quantificadas para posterior homogeneização antes da corrida. Para o experimento, diferentes tempos após o processo de eletroporação foram observados. As amostras consideradas foram a no tempo zero (imediatamente após o processo de eletroporação), meia hora após a eletroporação, uma hora, uma hora e meia, duas horas, quatro e seis horas. Uma amostra controle, onde ocorre apenas a colocação do eletrodo sem a aplicação dos pulsos elétricos também foi realizada. Seis amostras de cada tempo foram realizadas para as duas linhagens de células (B16/BL6 e B16/F10). Como podemos observar na figura 30 abaixo o tempo meia hora e uma hora apresentaram diminuição na quantidade de proteínas totais.

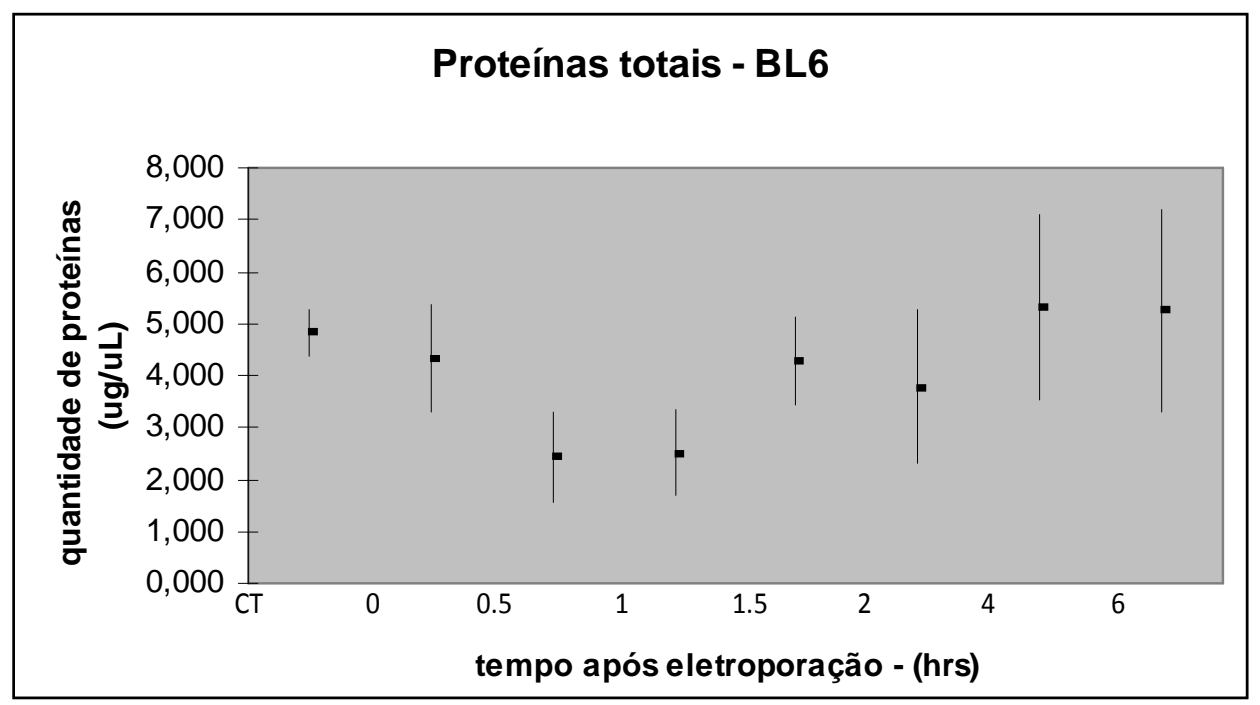

Figura 30 - Proteínas totais das amostras da linhagem B16/BL6 


\subsection{Gel e Membranas}

As membranas evidenciaram uma diminuição de marcação nos tempos 1/2 hora e 1 hora após a eletroporação. O gel de poliacrilamida apresentou marcação homogênea evidenciando uma correta quantificação e diluição de proteínas. A figura 31 abaixo evidencia o gel e as imunomarcações da Cx 26 e $\beta$-actina nas membranas. $O$ tempo $t_{1 / 2}$ apresenta diminuição nas marcações da $C \times 26$.

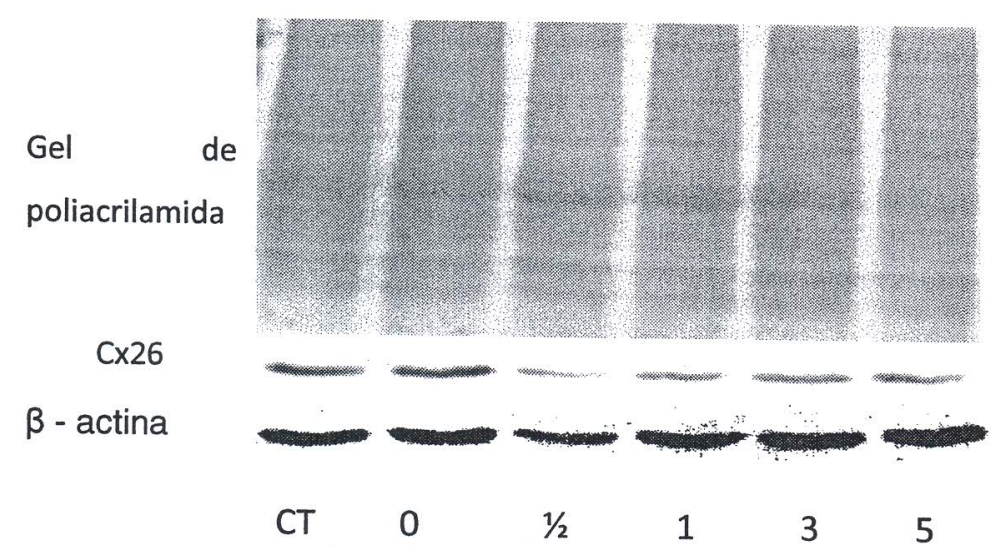

Figura31-Gel de poliacrilamida e imunomarcação na membrana de western blot para cx26 na linhagem B16/BL6, tendo como controle endógeno a $\beta$ actina. Podemos observar a diminuição na intensidade da marcação no tempo $1 / 2$ hora após a aplicação do campo elétrico. 
5.2.1.2.3 Quantificação da Cx26 através da analise densitométrica das membranas para linhagem B16/BL6

Conforme podemos observar na figura 32 o único grupo que apresenta diferença significativa de quantidade de proteínas após a realização da análise densitométrica das marcações nas membranas da técnica de western blot foi o grupo onde se extraiu o mRNA meia hora após a aplicação do campo elétrico.

Gráfico da densitometria da proteína Cx26 normalizada.

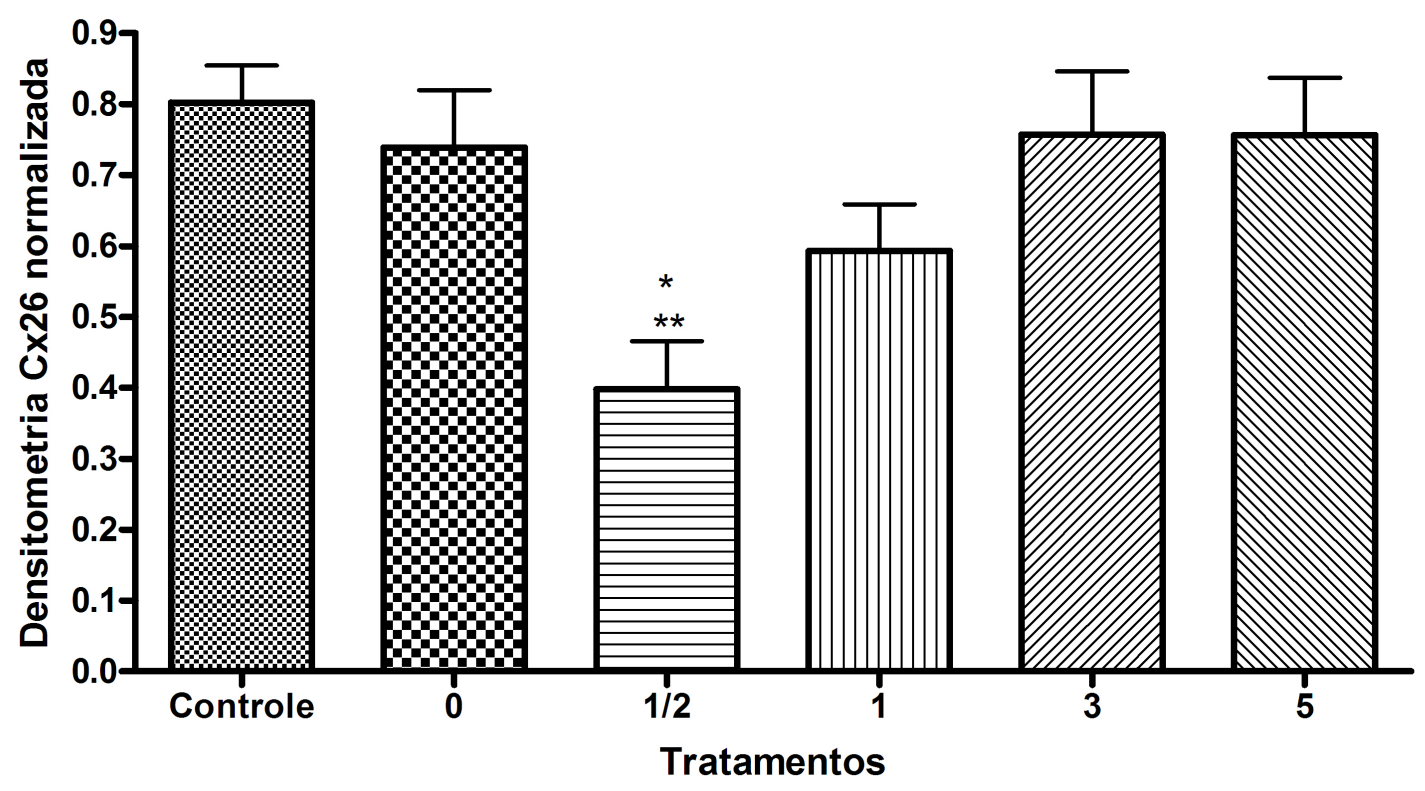

Figura 32- Gráfico da densitometria das marcações das membranas de western blot para cx26. Podemos observar que o grupo onde foi extraído o mRNA meia hora após a aplicação do campo elétrico foi o único onde se pôde observar uma redução com diferença significativa com os demais grupos. 
As seções subsequentes apresentam os resultados referentes à técnica de PCR em tempo real para a Cx 26 na linhagem de células B16/BL6.

5.2.1.3.1 Determinação dos níveis de transcrição de mRNA da Cx26 na linhagem B16/BL6 submetidas a eletroporação através da técnica de real time PCR.

A avaliação estatísticados resultados do PCR em tempo real da linhagem B16/BL6 mostraram que após a aplicação do campo elétrico ocorre uma diminuição significativa na quantidade de mRNA para Cx26. No tempo zero após a aplicação do campo elétrico a quantidade de mRNAse mantêm e a partir do tempo $1 / 2$ hora após a aplicação do campo elétrico os níveis caem drasticamente. Após este tempo os níveis se reestabelecem e se sustentam até 5 horas após a aplicação do campo. Estes resultados podem ser observados na figura 33 abaixo.

\section{Gráfico dos níveis de expressão de mRNA do gene Cx26 em células}

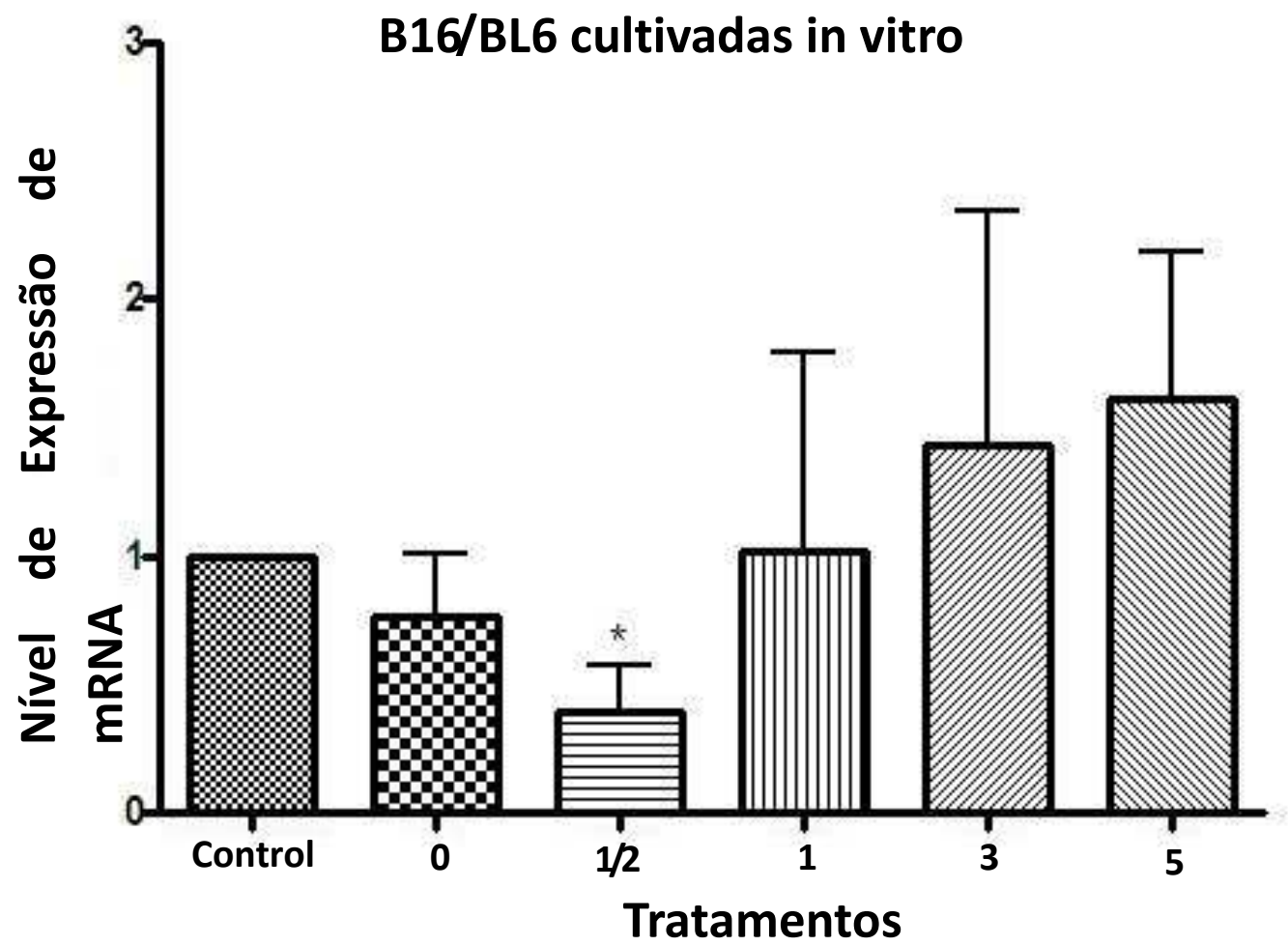

Figura 33- Níveis de expressão de RNAm para Cx26 em diferentes tempos após a eletroporação observados através da técnica de PCR em tempo real em células da linhagem de melanoma B16/BL6. Podemos observar que o grupo onde foi extraído o mRNA meia hora após a aplicação do campo elétrico foi o único onde se pôde observar uma redução com diferença significativa com os demais grupos. 
5.2.1 Resultados dos experimentos envolvendo as linhagens de pulmão E9 e E10.

A seguir são apresentados todos os resultados referentes aos experimentosin vitro realizados nas linhagens de células de pulmão E9 e E10.

\subsubsection{Imunofluorescência para Cx 43 na linhagem E10}

A técnica de Imunofluorescência para Cx 43 mostrou que a linhagem de células E10 apresenta imunomarcação para Cx 43 em membrana a também em citoplasma em todos os grupos. As figuras 34, 35, 36, 37, 38 e 39 abaixo mostram as imunomarcações para $C x 43$ referentes aos grupos controle, $T_{0}, T_{1 / 2}, T_{1}, T_{3}$ e $T_{5}$.

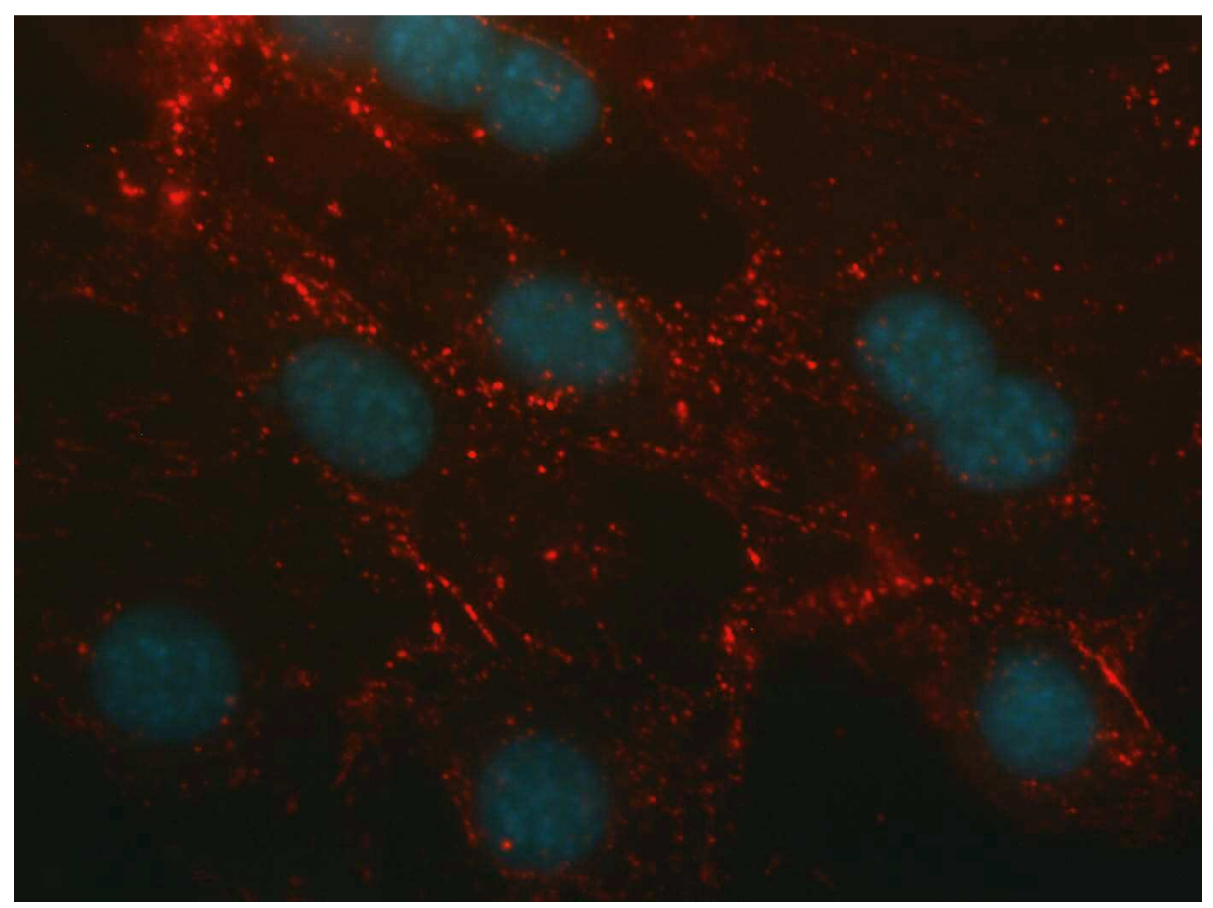

Figura34- Imunomarcação para Cx 43 no grupo controle na linhagem E10. Podemos observar tanto marcação em membrana quanto marcação em citoplasma. As imagens em cor vermelha representam a marcação da Cx 43 e em azul o núcleo. (objetiva 40x) 


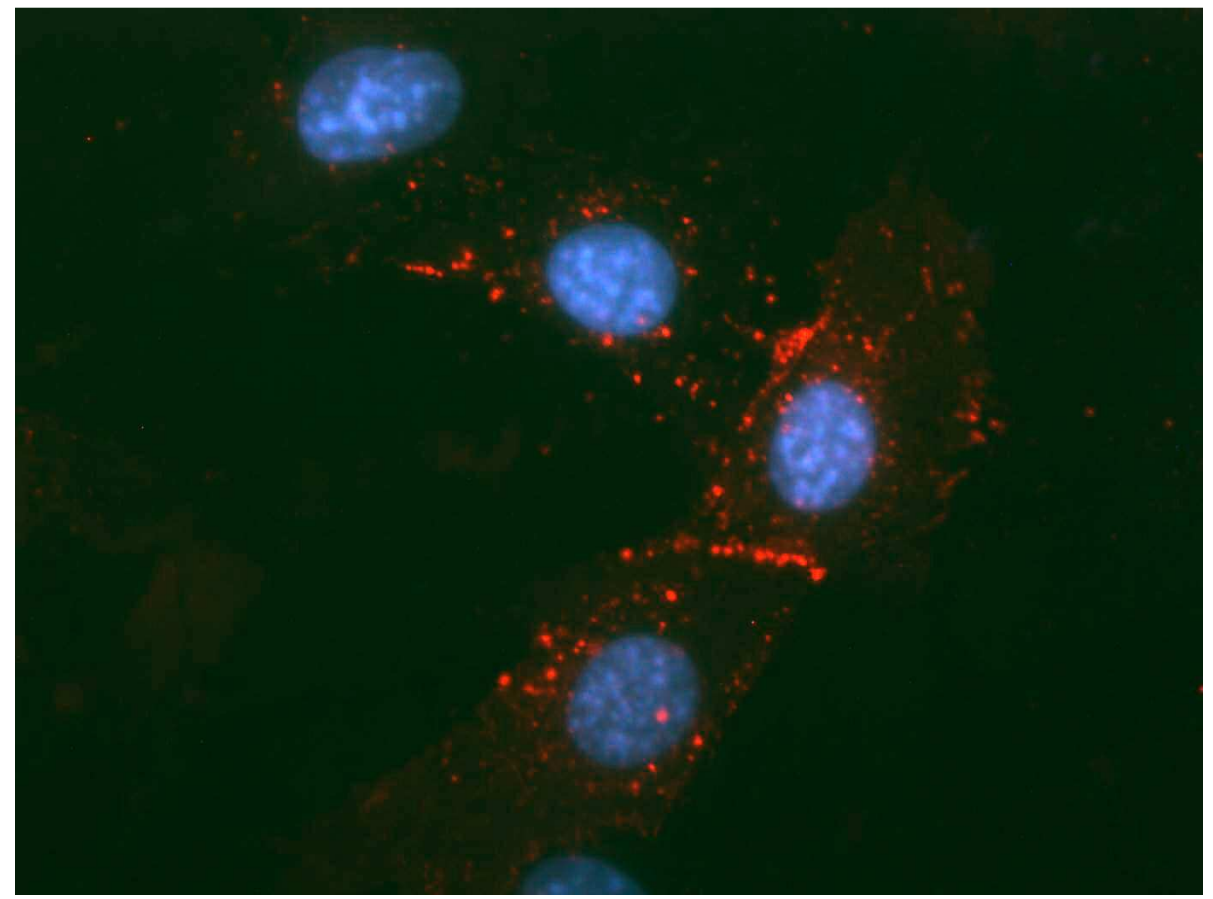

Figura35- Imunomarcação para Cx 43 no grupo to na linhagem E10. Podemos observar tanto marcação em membrana quanto marcação em citoplasma. As imagens em cor vermelha representam a marcação da Cx 43 e em azul o núcleo.(objetiva 40x)

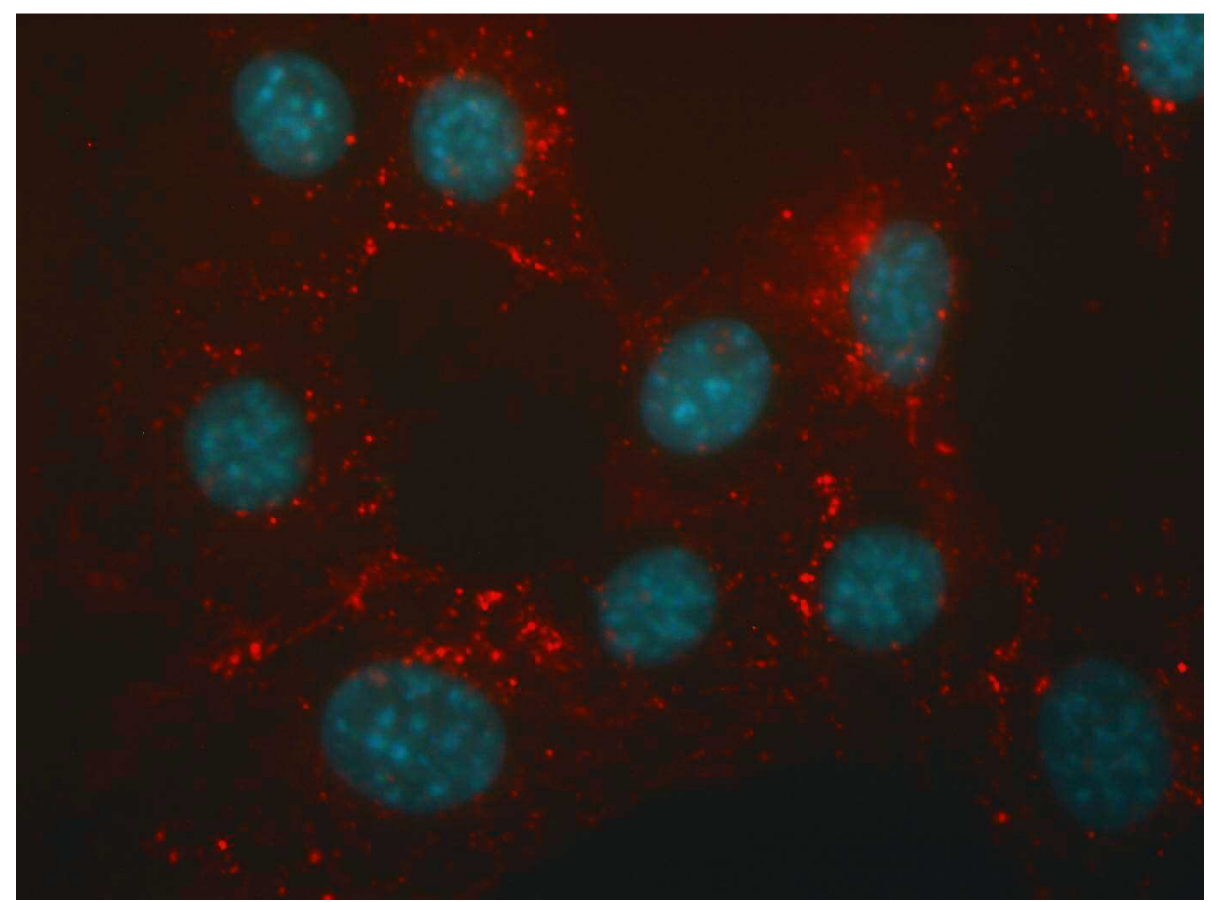

Figura36- Imunomarcação para $C x 43$ no grupo $t_{1 / 2}$ na linhagem E10. Podemos observar tanto marcação em membrana quanto marcação em citoplasma. As imagens em cor vermelha representam a marcação da Cx 43 e em azul o núcleo. (objetiva 40x) 


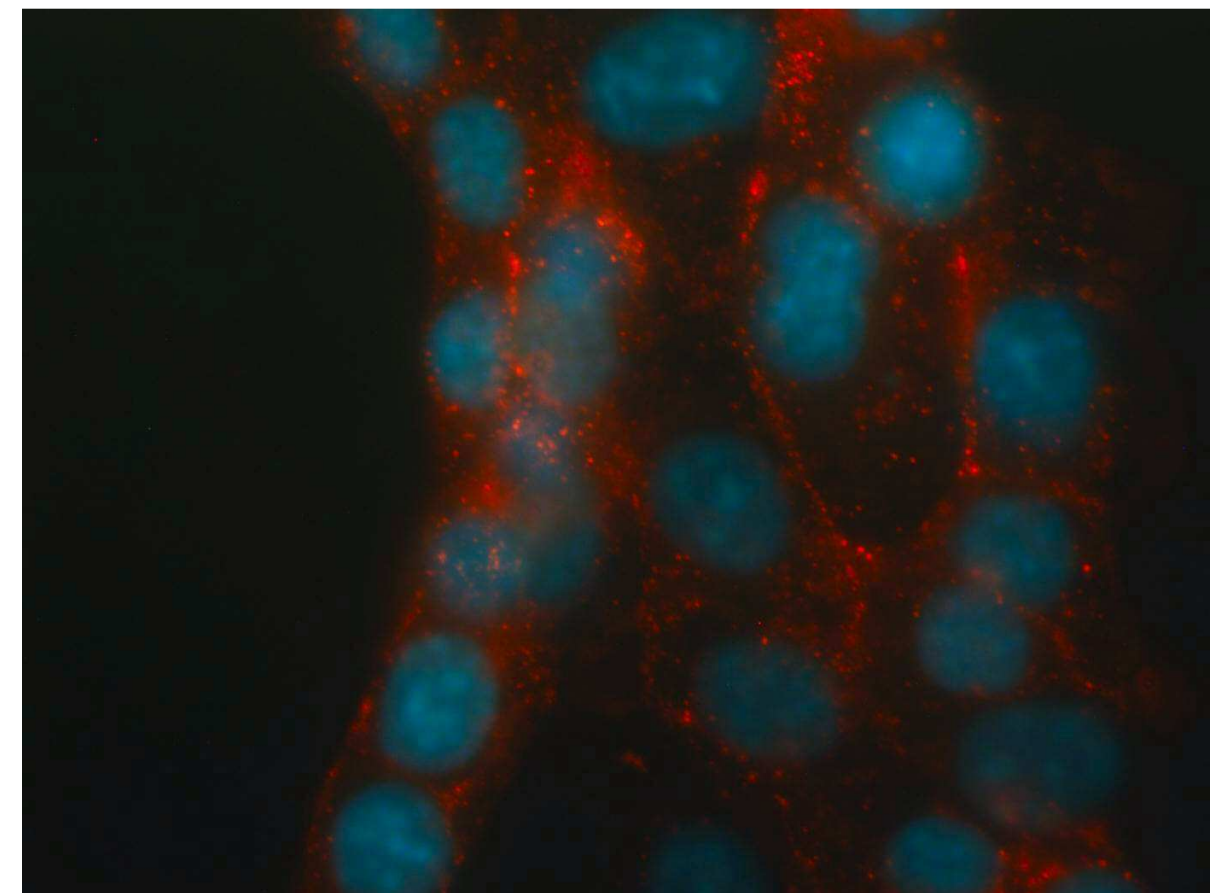

Figura37- Imunomarcação para $\mathrm{Cx} 43$ no grupo $t_{1}$ na linhagem E10. Podemos observar tanto marcação em membrana quanto marcação em citoplasma. As imagens em cor vermelha representam a marcação da Cx 43 e em azul o núcleo. (objetiva 40x)

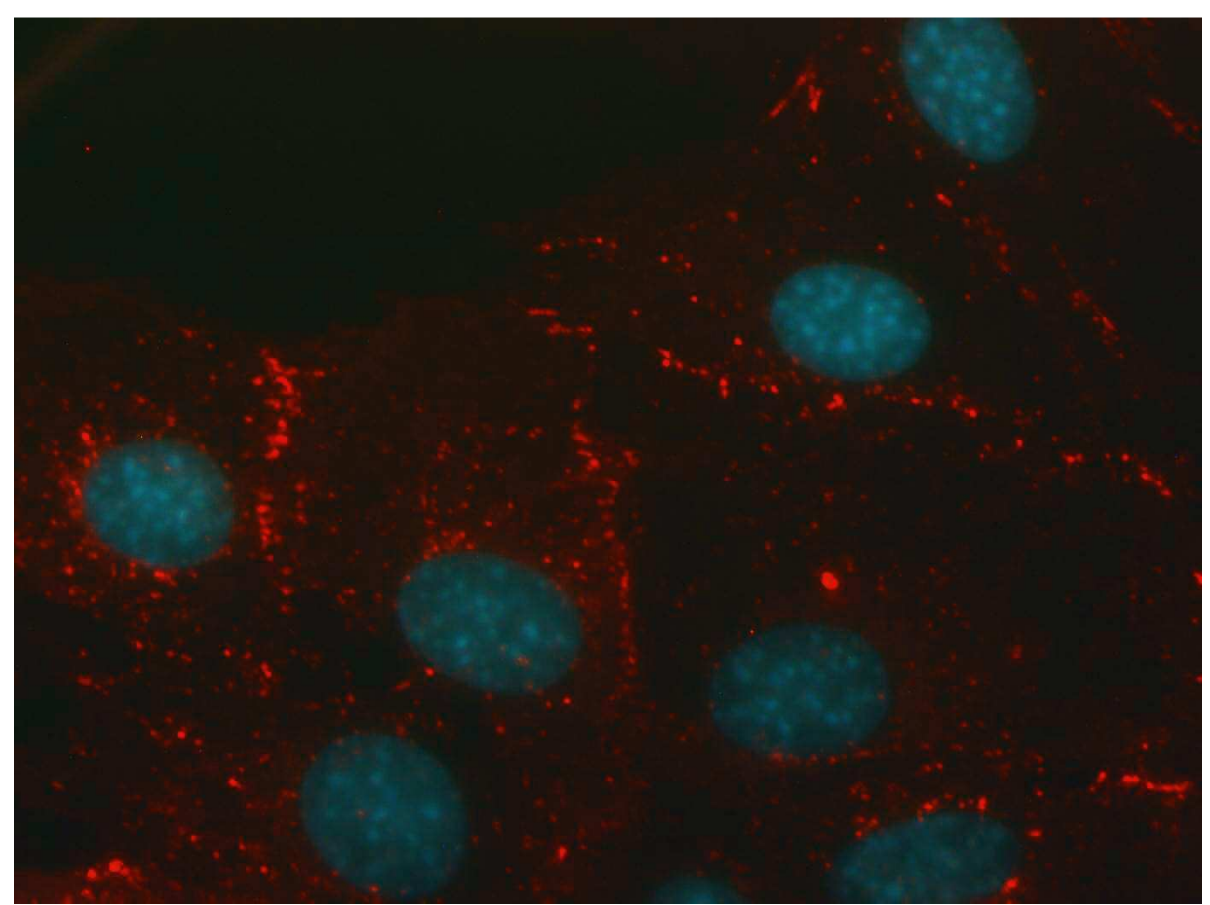

Figura38- Imunomarcação para $\mathrm{Cx} 43$ no grupo $t_{3}$ na linhagem E10. Podemos observar tanto marcação em membrana quanto marcação em citoplasma. As imagens em cor vermelha representam a marcação da Cx 43 e em azul o núcleo.(objetiva 40x) 


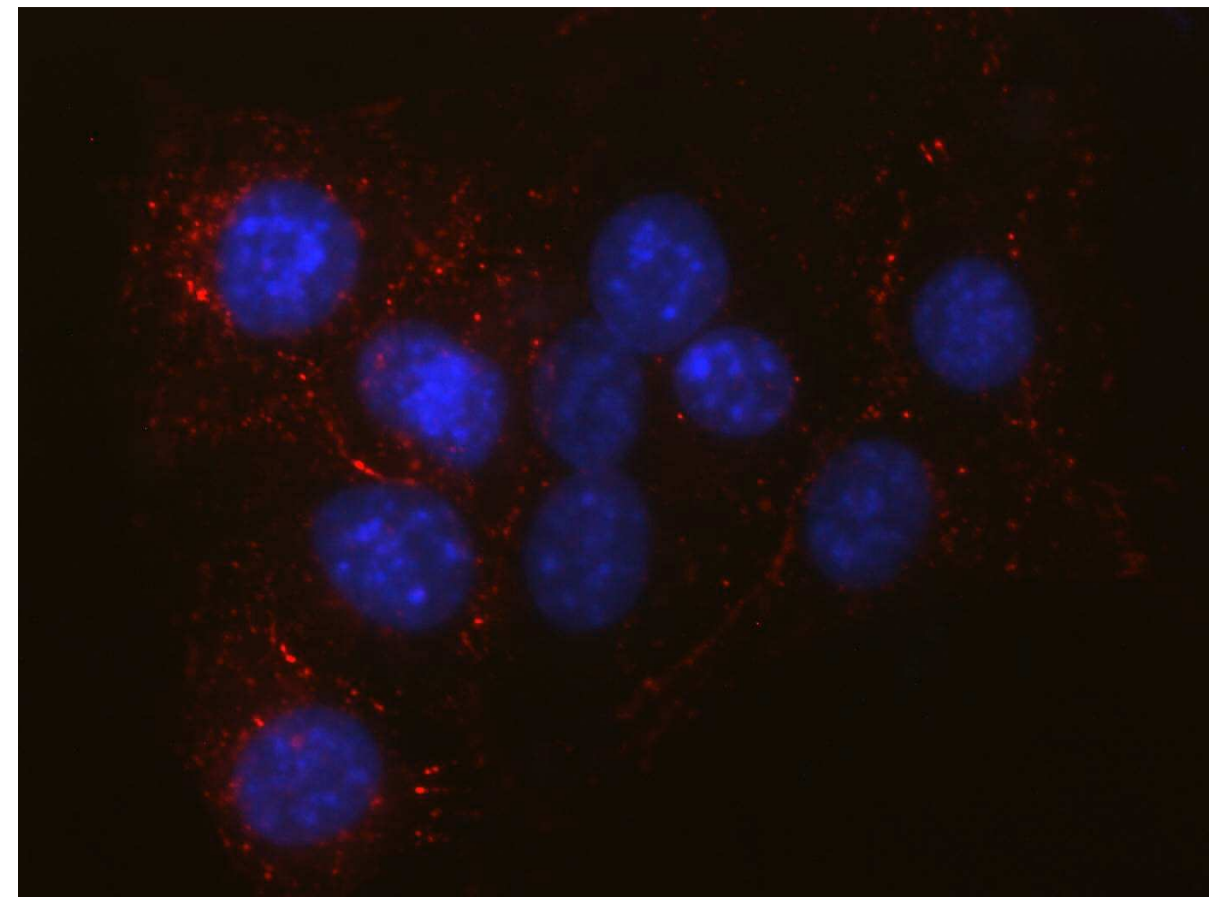

FIGURA 39Imunomarcação para Cx 43 no grupo t5 na linhagem E10. Podemos observar tanto marcação em membrana quanto marcação em citoplasma. As imagens em cor vermelha representam a marcação da Cx 43 e em azul o núcleo.(objetiva 40x) 
5.2.2.2 Imunofluorescência para Cx43 na linhagem E9

As imagens de imunofluorescência para Cx 43 na linhagem E9 mostraram uma marcaçãopredominantementeem membrana, embora também possamos observar marcação subcelular, possivelmente em citoplasma. Essas diferenças de marcação são visualizadas principalmente entre as imagens dos grupos ct, $t_{0}, t_{3}, t_{5} e$ dos grupos $t_{1 / 2}$ e $t_{1}$. Enquanto os grupos ct, $t_{0}, t_{3}$ e $t_{5}$ apresentam marcações predominantemente em membrana no grupo $t_{1 / 2}$ já se evidencia uma maior marcação em citoplasma, além da presença de marcação em membrana também. 0 grupo $t_{1 / 2}$ apresenta imagem com marcação predominantemente em citoplasma. Podemos observar nas figuras 40, 41, 42, 43, 44 e 45essas diferenças de marcação.

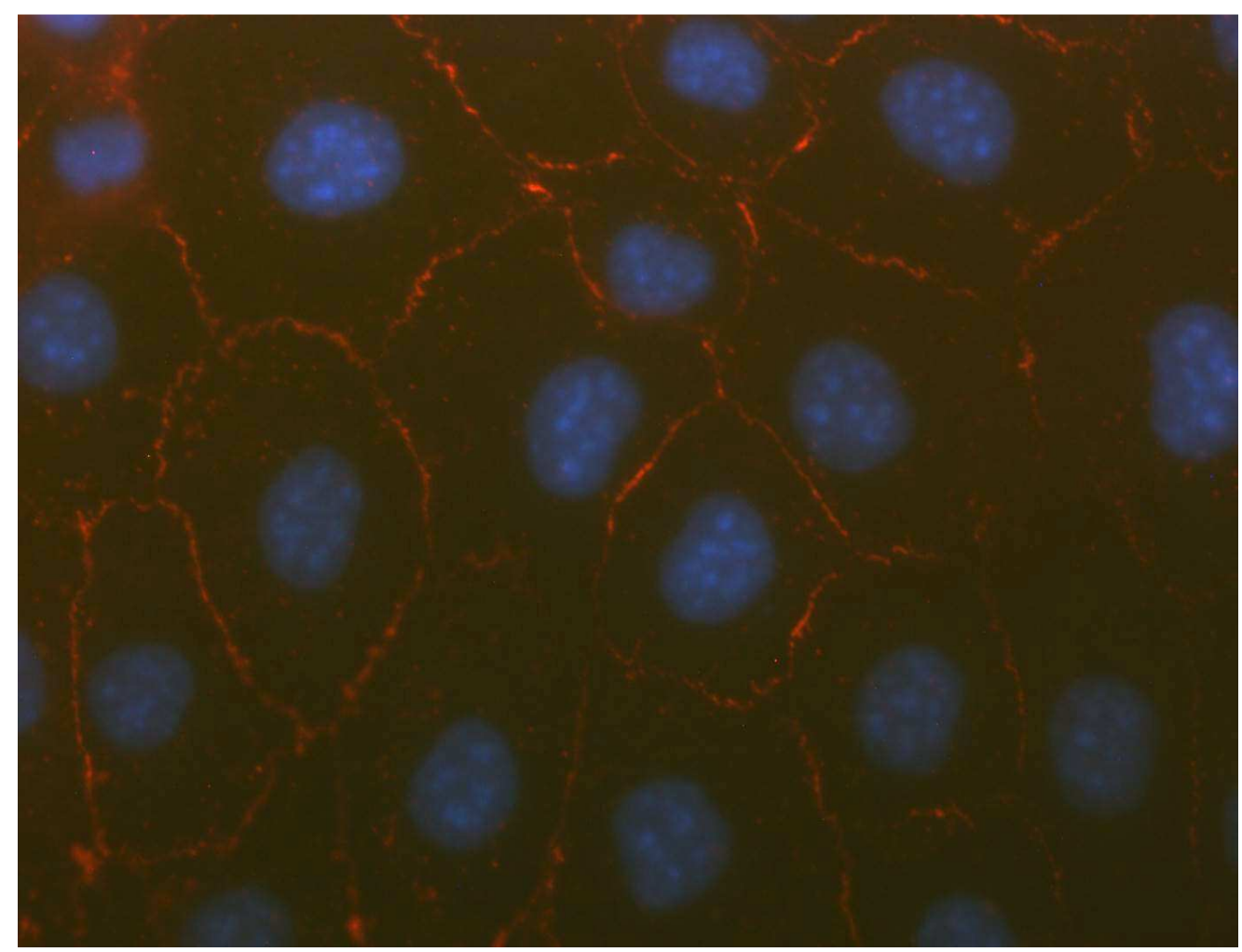

Figura40- Imunomarcação para Cx 43 no grupo ct na linhagem E9. Podemos observar uma marcação predominante em membrana. As imagens em cor vermelha representam a marcação da Cx 43 e em azul o núcleo.(objetiva 40x) 


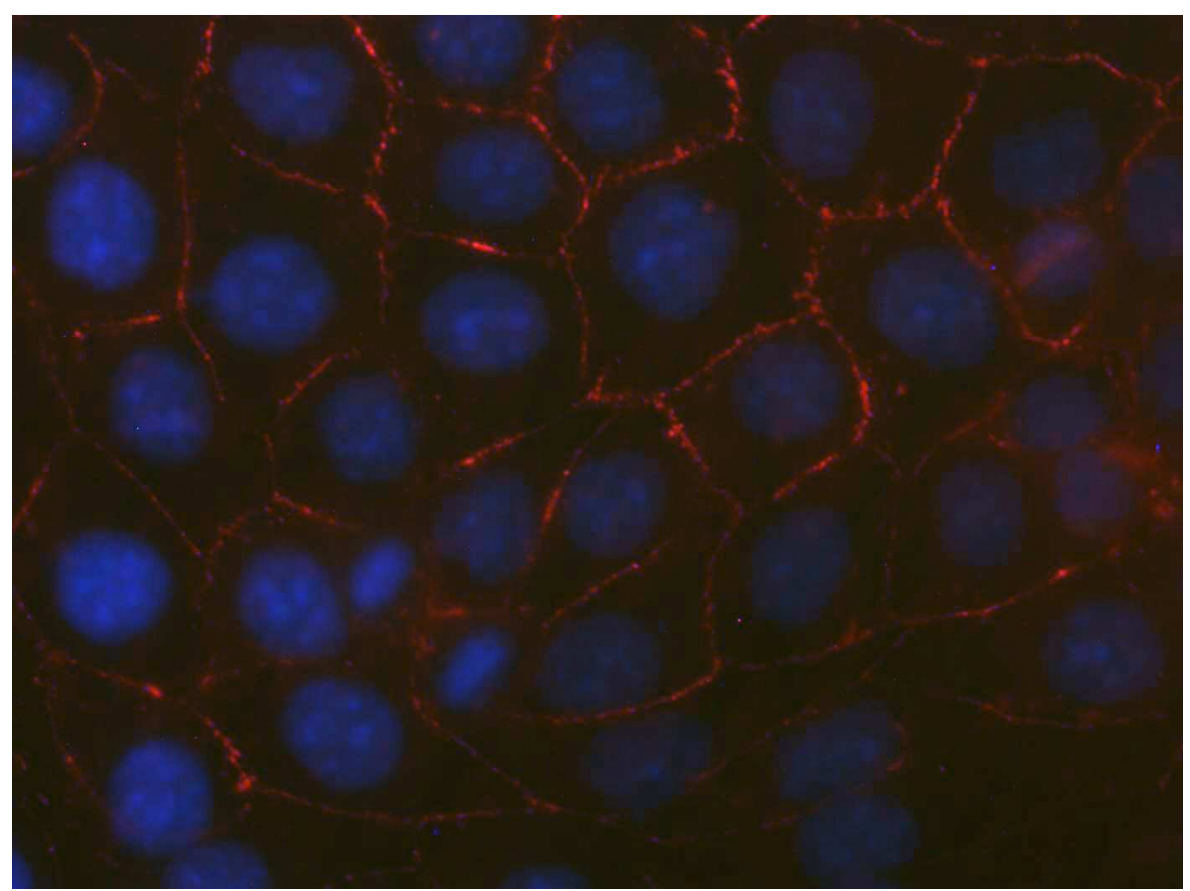

Figura41- Imunomarcação para $\mathrm{Cx} 43$ no grupo to na linhagem E9. Podemos observar uma marcação predominante em membrana. As imagens em cor vermelha representam a marcação da Cx 43 e em azul o núcleo.(objetiva 40x)

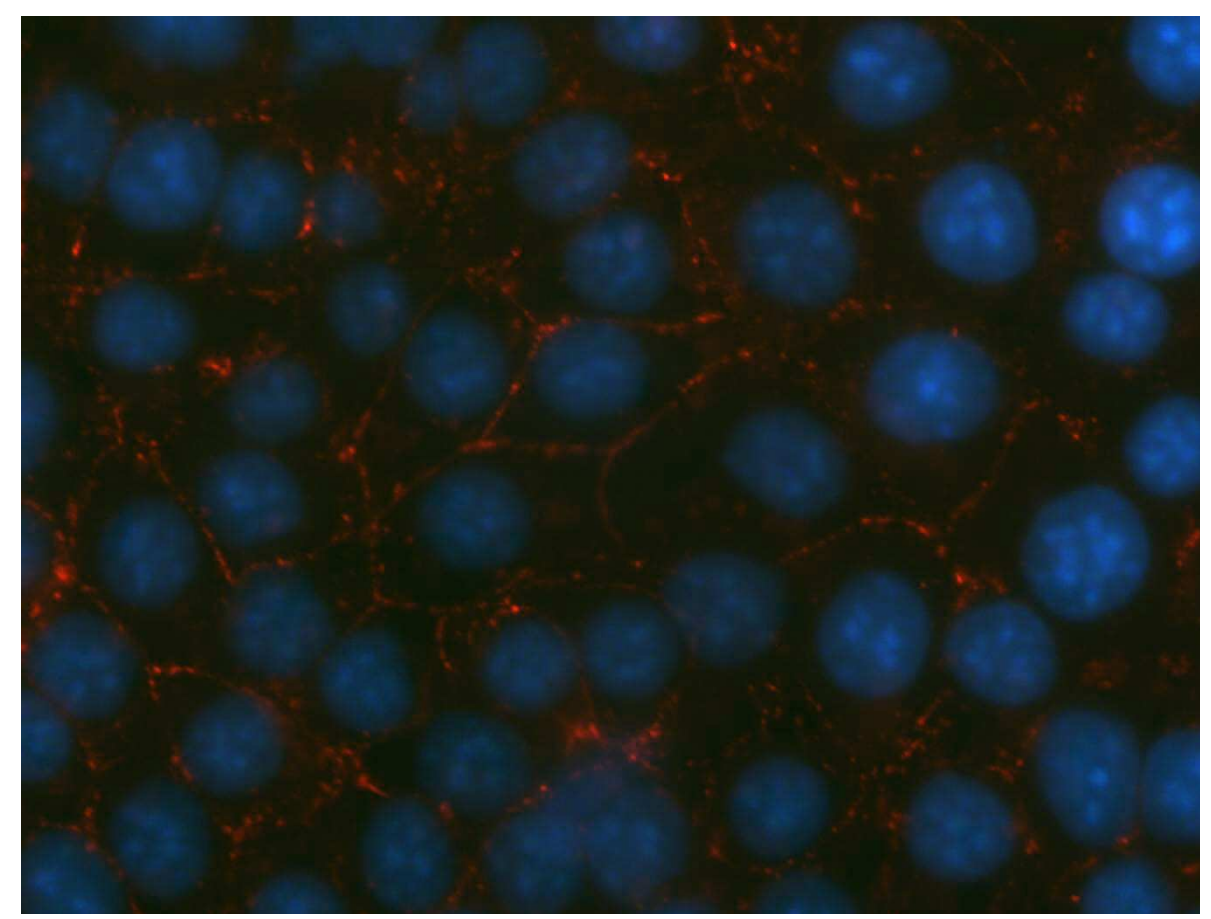

Figura42- Imunomarcação para $C x 43$ no grupo $t_{1 / 2}$ na linhagem E9. Podemos observar uma marcação predominante em membrana, porém com um aumento de marcação em citoplasma. As imagens em cor vermelha representam a marcação da Cx 43 e em azul o núcleo. (objetiva 40x) 


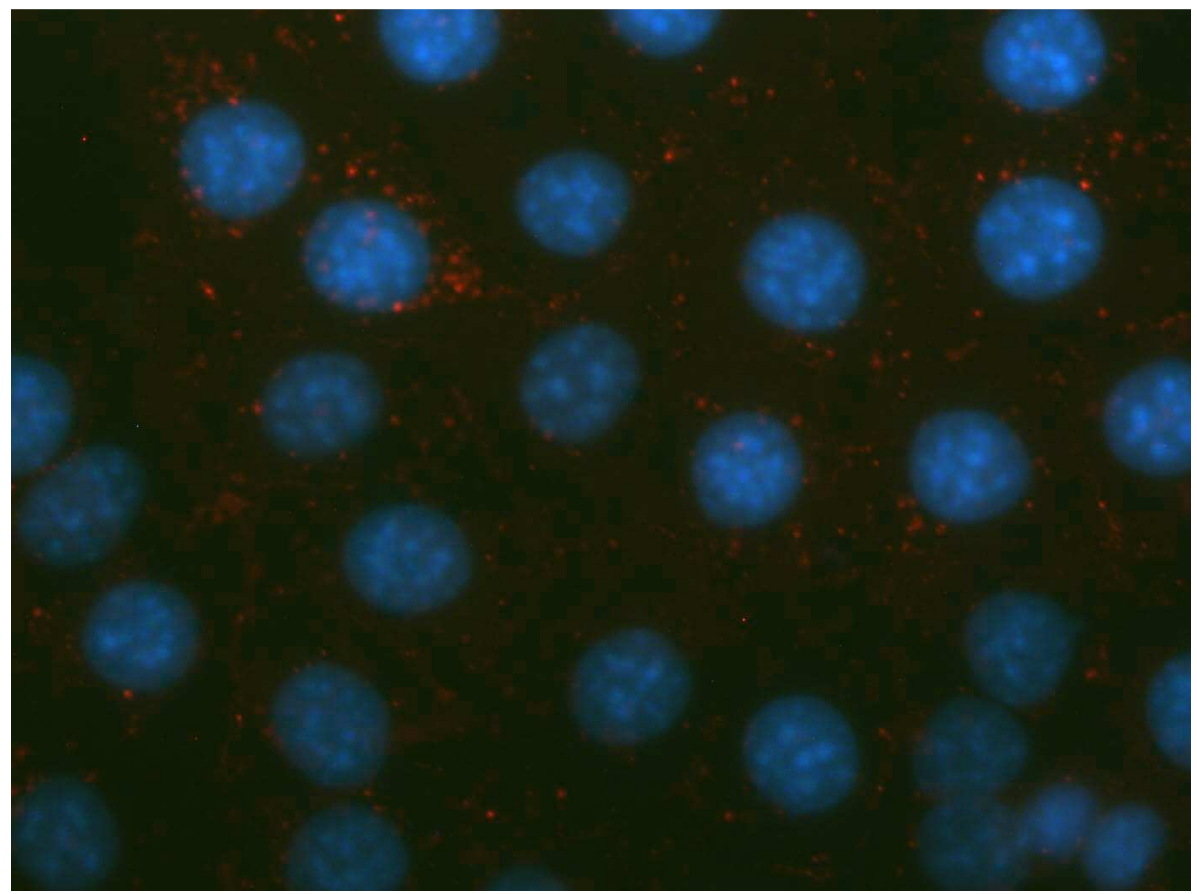

Figura43- Imunomarcação para $C x 43$ no grupo $t_{1}$ na linhagem E9. Podemos observar marcação somente em citoplasma. As imagens em cor vermelha representam a marcação da Cx 43 e em azul o núcleo. (objetiva 40x)

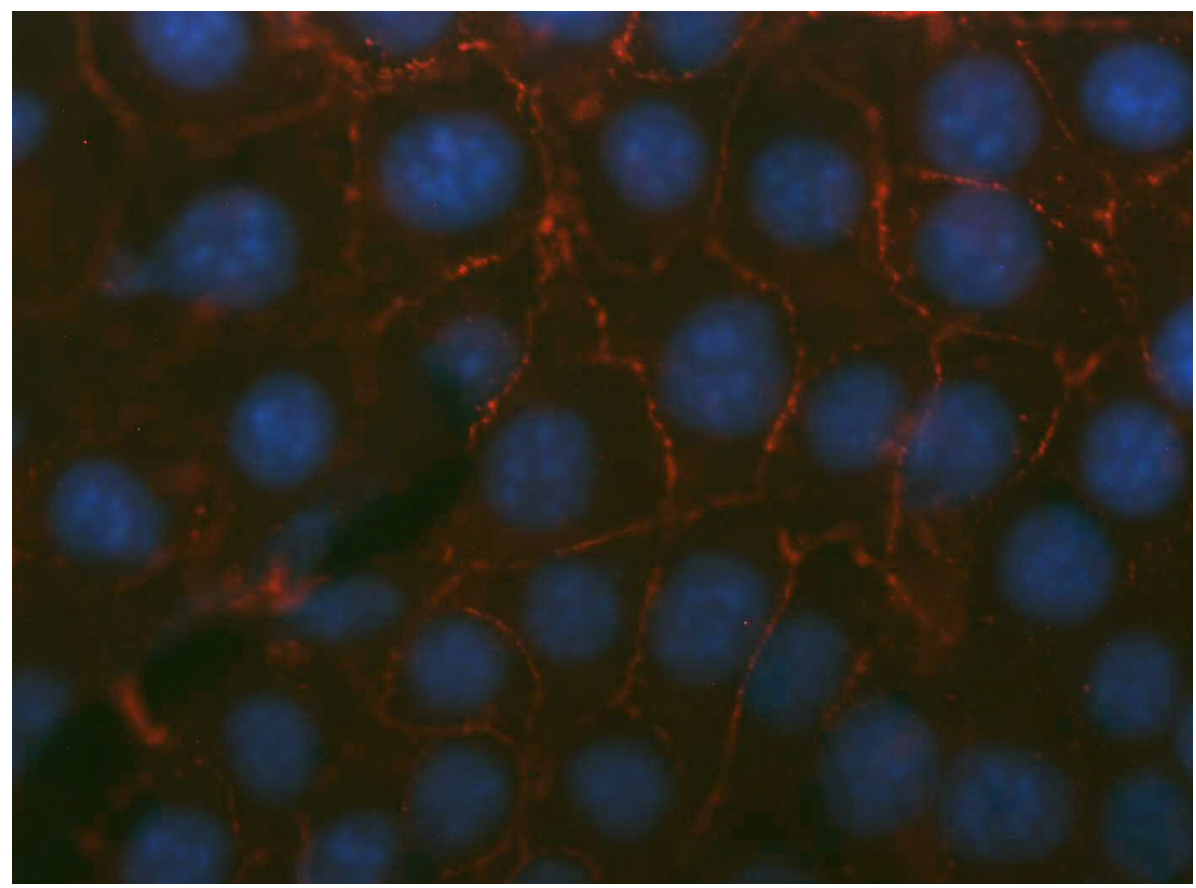

Figura44- Imunomarcação para $C x 43$ no grupo $t_{3}$ na linhagem E9. Podemos observar uma marcação predominante em membrana. As imagens em cor vermelha representam a marcação da Cx 43 e em azul o núcleo. (objetiva 40x) 


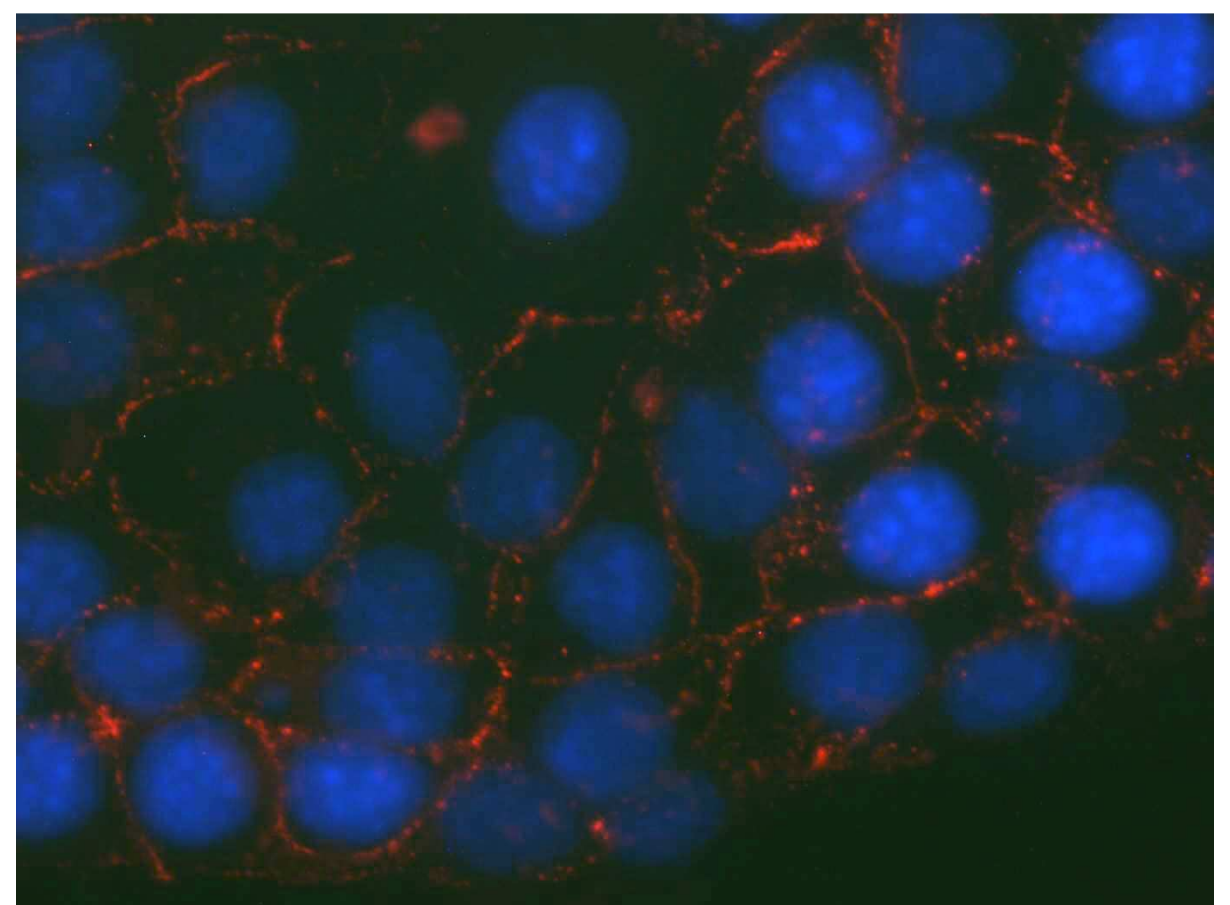

Figura45- Imunomarcação para Cx 43 no grupo ts na linhagem E9. Podemos observar uma marcação predominante em membrana. As imagens em cor vermelha representam a marcação da Cx 43 e em azul o núcleo. (objetiva 40x) 
5.2.2.3 Western blot para Cx 43 na linhagenE10

A seguir serão apresentados os resultados referentes à técnica de western blotparaCx 43 na linhagem de pulmão E10.

\subsection{Gel e Membranas para linhagem E10}

O gel e membranas da técnica de western blot, presentes na figura 46 abaixo, apresentam uma marcação homogênea e as marcações para $C x 43$ e $\beta$-actina respectivamente. Na membrana de western blot,é possível observar uma diminuição na imunomarcaçãoparaCx 43 nos tempos $t_{1 / 2} \mathrm{t}_{1}$.

Gel de

poliacrilamida

Cx43

$\beta$-actina

ct

$t_{0}$

$t_{1 / 2}$

$t_{1}$

$t_{3}$

$t_{5}$

Figura 46 - Gel de poliacrilamida e imunomarcação na membrana de western blot para $\mathrm{Cx43}$ na linhagem $E 10$, tendo como controle endógeno a $\beta$ actina. A imunomarcação para Cx 43 nos tempos $t_{1 / 2}$ e $t_{1}$ foram diminuídas. 
5.2.2.3.2 Quantificação da Cx43 através da analise densitométrica das membranas para linhagem E10

Com os resultados desta técnica pôde-se observar que a avaliação densitométrica das membranas para $\mathrm{aCx} 43$ na linhagem de células E10, uma linhagem não neoplásica, não apresentou diferença significativa entre os diferentes tempos após o processo de eletroporação, conforme nos mostra a figura 47abaixo. A avaliação denistométrica foi feita comparando-se o pico de intensidade da marcação da cx43 com o pico do controle endógeno, no caso a $\beta$-actina.

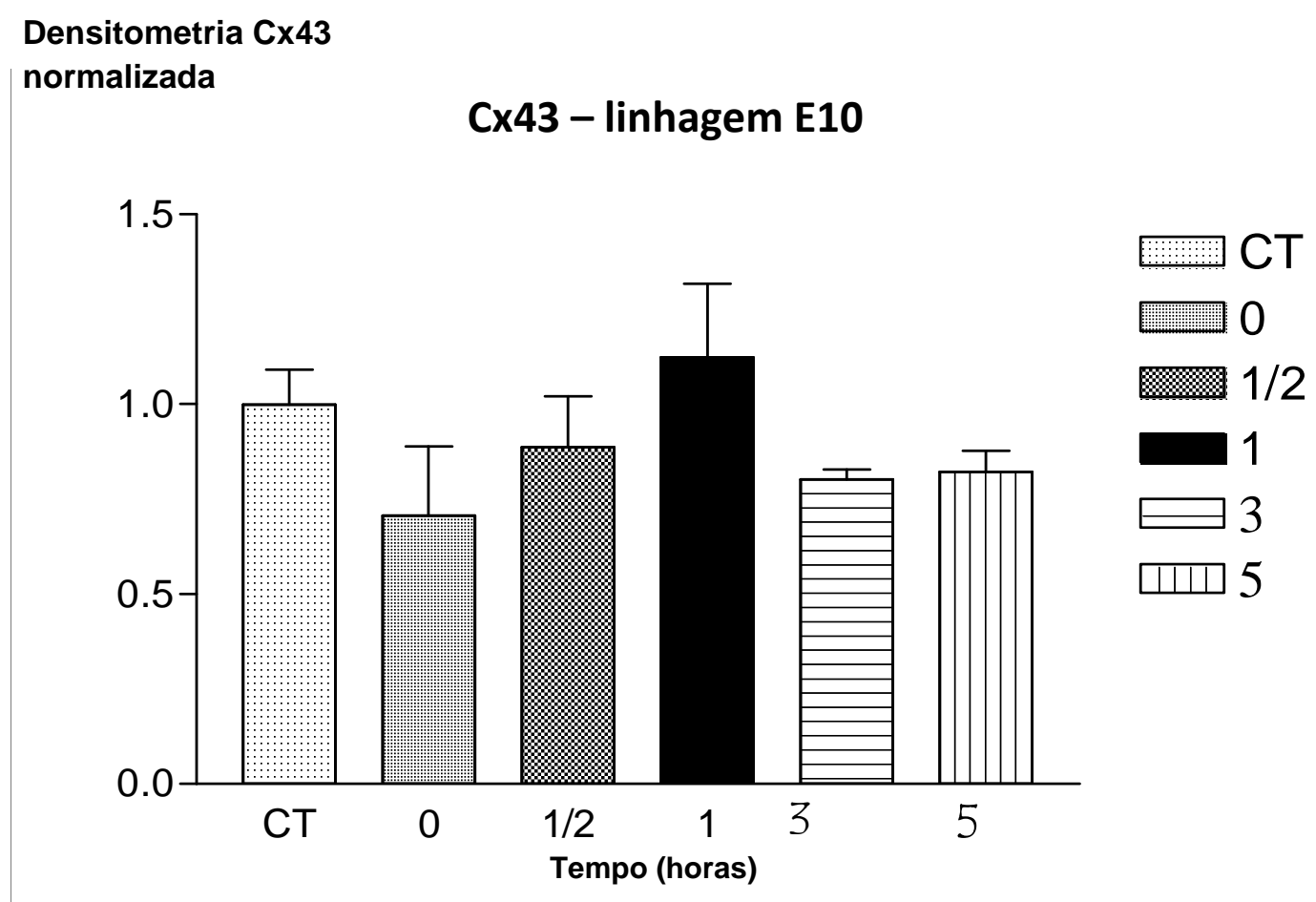

Figura 47 -Avaliação da interferência da eletroporação na cx43 em diferentes tempos após a aplicação do campo elétrico. Podemos observar que não há diferença significativa entre os diferentes tempos $(p<0,05)$. 


\subsubsection{Western blot para Cx 43 na linhagen E9}

A seguir serão apresentados os resultados referentes a técnica de western blotpara Cx 43 na linhagem neoplásica de pulmão E9.

\subsection{Gel e Membranas para linhagem E9}

O gel e membranas da técnica de western blot, presentes na figura 48 abaixo, apresentam uma marcação homogênea e as marcações para $C x 43$ e $\beta$-actina respectivamente. Na membrana de western blot,é possível observar uma diminuição marcante na imunomarcaçãopara $\mathrm{Cx} 43$ apenas no tempo tempos $t_{1 / 2}$. $O$ tempo $t_{1}$ também apresenta uma diminuição sutil na marcação para Cx 43.

Gel de

poliacrilamida

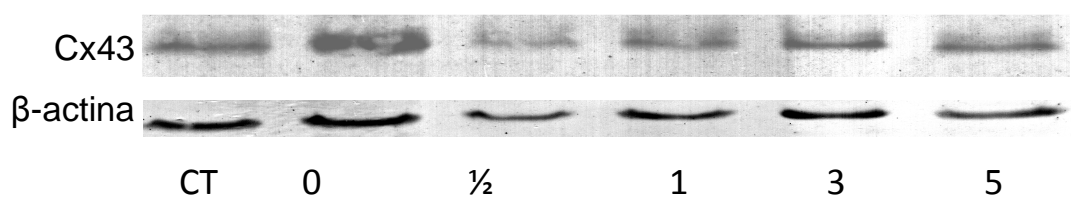

Figura 48 -Gel de poliacrilamida e imunomarcação na membrana de western blot para $C \times 43$ na linhagem E9, tendo como controle endógeno a $\beta$ actina. A marcação para $\mathrm{Cx} 43$ no tempo $t_{1 / 2}$, foisensilvemente diminuída e no tempo $t_{1}$ teve diminuição sutil. 
5.2.2.4.2 Quantificação da Cx43 através da analise densitométrica das membranas para linhagem E9

Com os resultados desta técnica pôde-se observar que a avaliação densitométrica das membranas para a $C x 43$ na linhagem de células E9, uma linhagem neoplásica, apresentou diferença significativa apenas entre os tempos $\mathrm{t}_{1 / 2} \mathrm{e}$ $t_{1} \mathrm{e}$ os demais grupos após o processo de eletroporação, conforme nos mostra a figura 49abaixo. A avaliação denistométrica foi feita comparando-se o pico de intensidade da marcação da cx43 com o pico do controle endógeno, no caso a $\beta$ actina.

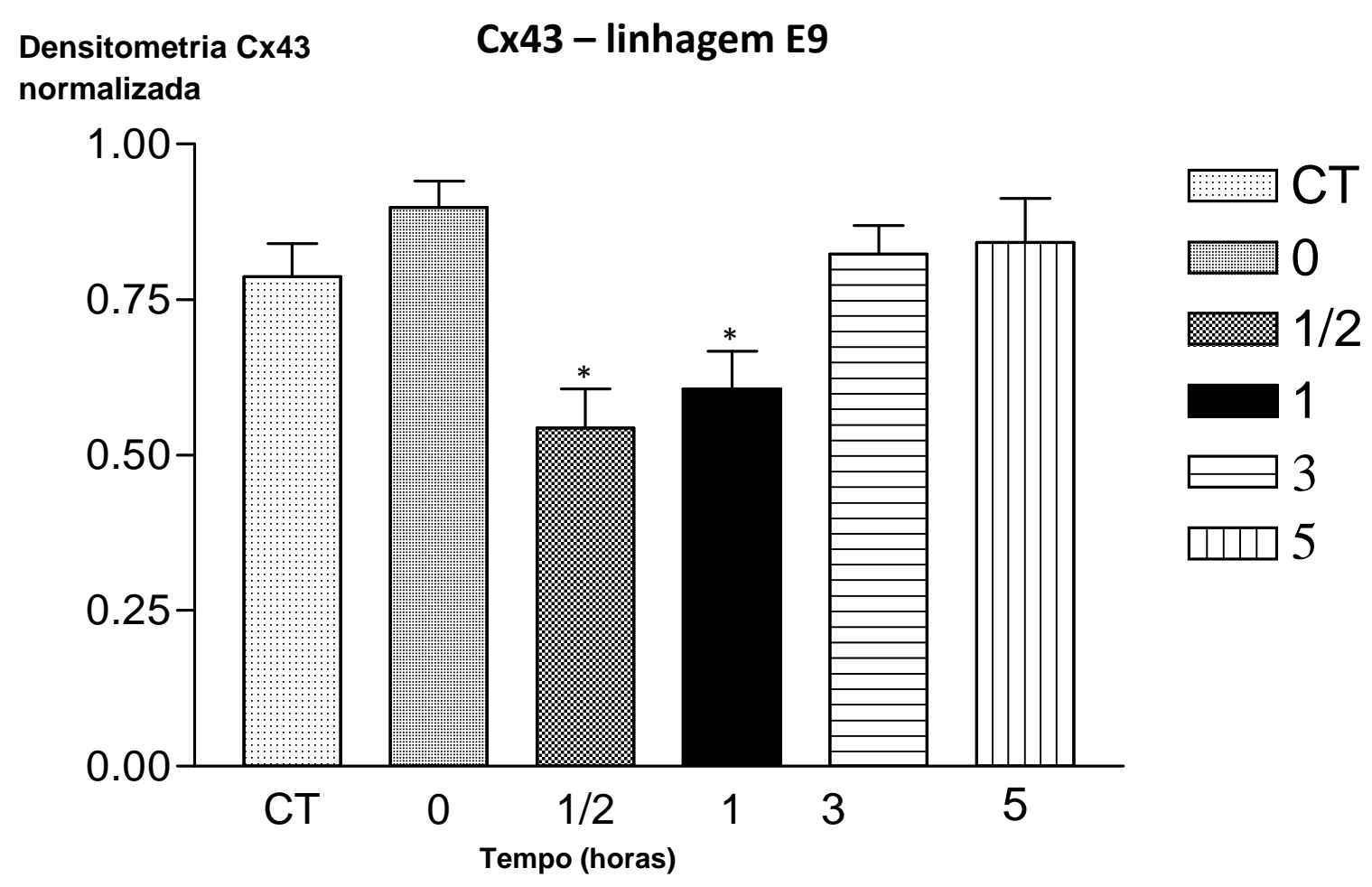

Figura 49 -Avaliação da interferência da eletroporação na cx43 em diferentes tempos após a aplicação do campo elétrico. Podemos observar que há diferença significativa somente entre os tempos $t_{1 / 2}$ e $t_{1}$ e os demais grupos $(p<0,05)$. 
5.2.2.5 PCR em tempo real para Cx 43na linhagen E10

Na sequencia são apresentados os resultados da técnica de PCR em tempo real para a Cx 43 na linhagem de pulmão E10.

5.2.2.4.3 Extração e quantificação do mRNA total das amostras da linhagem de células E10

As amostras demonstraram quantidade de mRNA total suficiente segundo avaliação no biofotômetro conforme tabela3descrita abaixo.

Tabela3- Tabela de concentração de mRNA total para a linhagem de células E10 .

\begin{tabular}{|c|c|c|c|c|c|c|}
\hline & \multicolumn{6}{|c|}{ Linhagem de células E10 } \\
\hline Tempo após & \multicolumn{6}{|c|}{ Concentração total de mRNA (ng/ $\mu \mathrm{l}$ ) } \\
\hline $\mathrm{CT}$ & 256 & 255 & 276 & 244 & 213 & 226 \\
\hline 0 & 223 & 272 & 265 & 219 & 241 & 281 \\
\hline $1 / 2$ & 178 & 195 & 179 & 186 & 174 & 210 \\
\hline 1 & 273 & 269 & 265 & 259 & 278 & 246 \\
\hline 3 & 146 & 143 & 186 & 178 & 165 & 154 \\
\hline 5 & 186 & 175 & 186 & 182 & 156 & 191 \\
\hline
\end{tabular}


5.2.2.5.2 Resultados do PCR em tempo real para Cx43 na linhagem de células E10.

Os resultados da técnica de PCR em tempo real para Cx 43 mostram que a partir do tempo $t_{1 / 2}$ após a eletroporação ocorre um aumento significativo na transcrição de RNAm para $C x 43$ que se sustenta no tempo $t_{1}$. Em $t_{3}$ ocorre um pico de transcrição.No tempo t5é observada avolta aos níveis dos tempos $t_{1 / 2}$ e $t_{1}$ A figura 50 abaixo evidencia estes resultados.

\section{Expressão mRNA Cx43 E10}

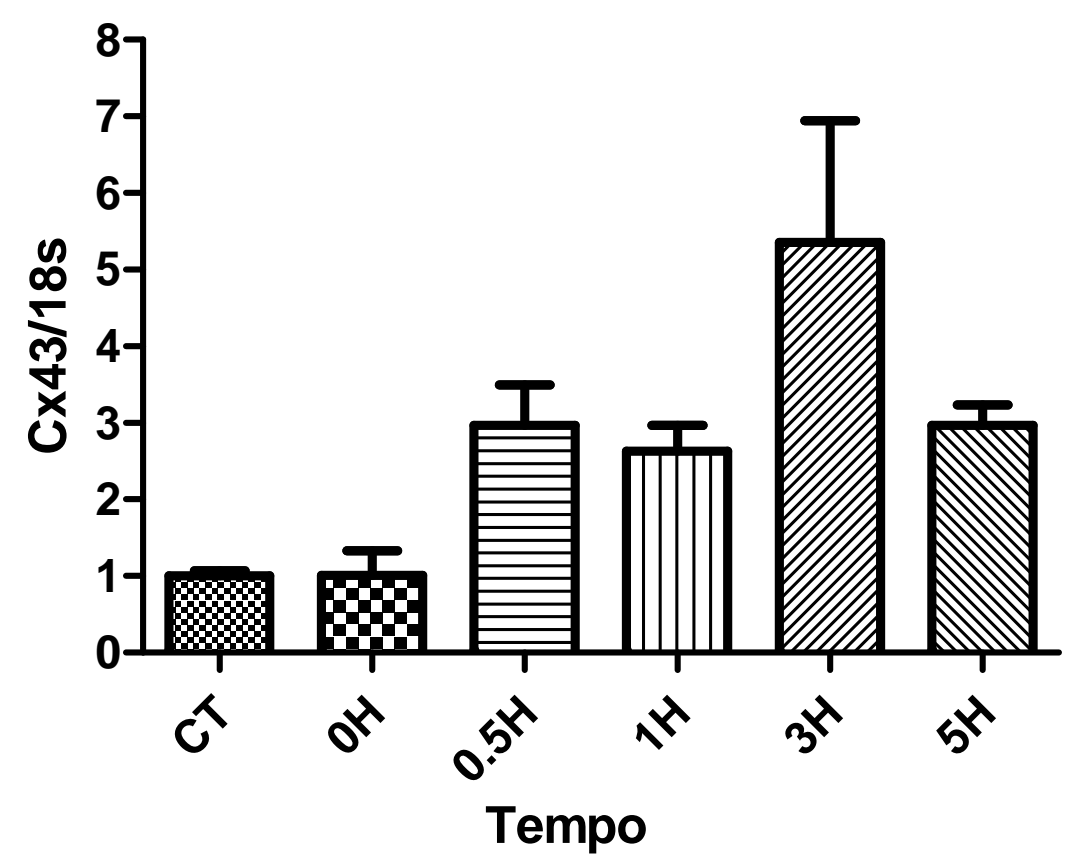

Figura 50 -Avaliação da interferência da eletroporação na transcrição de RNAm para cx43 em diferentes tempos após a aplicação do campo elétrico. Podemos observar que há um aumento da transcrição no tempo $t_{1 / 2}$ que se sustenta em $t_{1}$. No tempo $t_{3}$ ocorre um pico de transcrição, que volta aos valores de $t_{1 / 2}$ e $t_{1}$ no tempo $t_{5}(p<0,05)$. 
5.2.2.6 PCR em tempo real para Cx 43 na linhagenE9

Na sequencia são apresentados os resultados da técnica de PCR em tempo real para a Cx 43 na linhagem de pulmão E9.

5.2.2.6.1 Extração e quantificação do RNAm total das amostras da linhagens de células E9

As amostras demonstraram quantidade de RNAmtotal suficiente segundo avaliação no biofotômetro conforme tabela4descrita abaixo.

TABELA 4- Tabela de concentração de RNAm total para a linhagem de células E9 .

\begin{tabular}{|c|c|c|c|c|c|c|}
\hline \multicolumn{7}{|c|}{ Linhagem de células E9 } \\
\hline $\begin{array}{c}\text { Tempo após } \\
\text { EP }\end{array}$ & \multicolumn{6}{|c|}{ Concentração de RNAm (ng/dl) } \\
\hline CT & 258 & 222 & 206 & 198 & 265 & 244 \\
\hline 0 & 323 & 293 & 250 & 228 & 213 & 285 \\
\hline $1 / 2$ & 454 & 389 & 312 & 375 & 269 & 287 \\
\hline 1 & 233 & 244 & 281 & 232 & 217 & 245 \\
\hline 3 & 240 & 248 & 213 & 220 & 278 & 261 \\
\hline 5 & 169 & 172 & 215 & 234 & 210 & 195 \\
\hline
\end{tabular}


5.2.2.6.2 Resultados do PCR em tempo real para Cx43 na linhagem de células E9.

Os resultados da técnica de PCR em tempo real mostram que a partir do tempo toapós a eletroporação ocorre um pico na transcrição de mRNA para Cx 43 que se sustenta no tempo $t_{1 / 2}$. Em $t_{1}$ ocorre uma diminuição drástica na transcrição de mRNA para Cx 43. No tempo $t_{3}$ é observada avolta aos níveis dos tempos $t_{1 / 2}$ e $t_{0} e$ em $t_{5}$ a diminuição drástica visualizada em $t_{1}$ ocorre novamente. A figura 50 abaixo evidencia estes resultados.

\section{Expressão mRNA Cx43 E9}

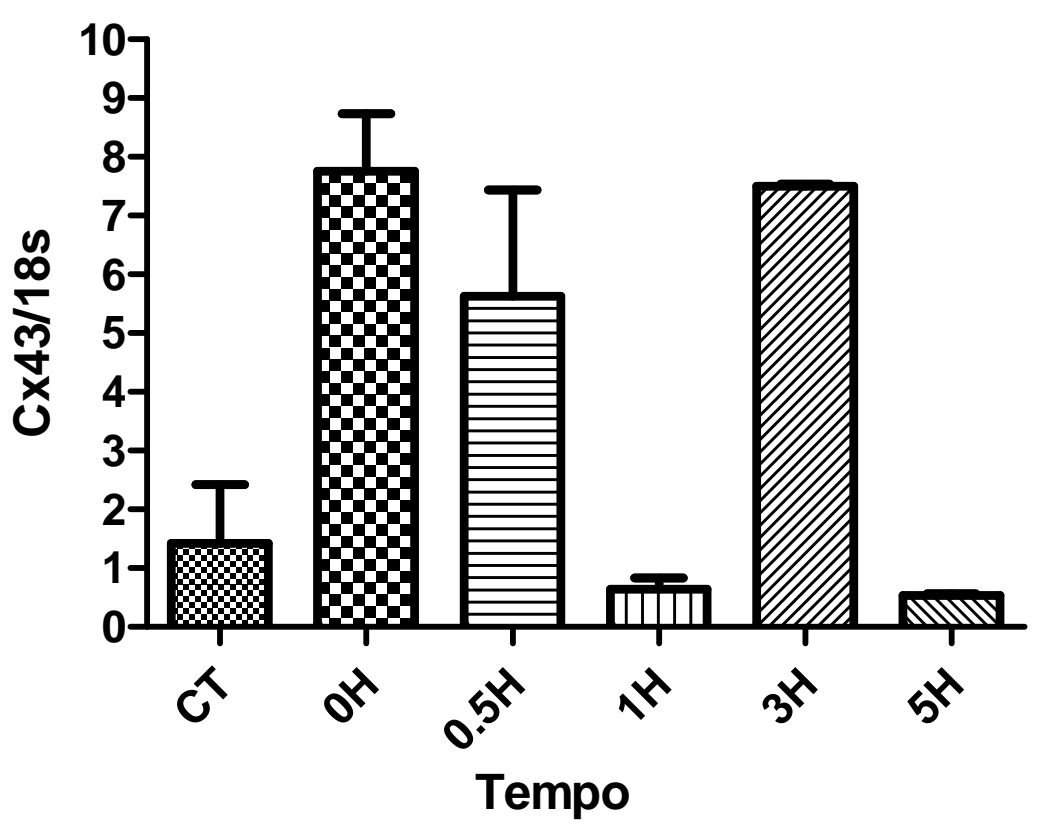

Figura 51 - Avaliação da interferência da eletroporação na transcrição de mRNA para cx43 em diferentes tempos após a aplicação do campo elétrico. Podemos observar que há um aumento da transcrição no tempo $t_{0}$ que se sustenta em $t_{1 / 2}$. No tempo $t_{1}$ ocorre uma diminuição drástica nos níveis de transcrição. Em $t_{3}$ os níveis voltam a valores semelhantes ao pico encontrado em $t_{0}$. Em $t_{5}$ volta a acontecer diminuição drástica nos níveis de transcrição de maneira semelhante a encontrada $\mathrm{em} \mathrm{t}_{3}$. 


\section{DISCUSSÃO}

Desde o inicio da década de 70, quando se descreveu o fenômeno de eletroporação, até o presente momento, muitos trabalhos de pesquisa têm sido feitos no sentido de se melhor compreender o fenômeno. Hoje a técnica é amplamente utilizada como ferramenta para realização de transfecção gênica em laboratórios e com boa perspectiva de futuras aplicações clínicas através da terapia gênica. Há aproximadamente duas décadas o fenômeno vem sendo estudado para utilização na eletroquimioterapia, uma nova terapia contra o câncer, sendo que há cerca de 4 anos a técnica foi padronizada para utilização na comunidade Européia. Hoje ela é desenvolvida em mais de 60 centros de tratamento contra o câncer (MIKLAVCIC et al., 2010). Especificamente na técnica de eletroquimioterapia, embora os mecanismos principais envolvidos na técnica estejam evidentes, o efeito predominantemente seletivo que se observa ao tecido neoplásico, quando a administração do agente antineoplásico ocorre por via intravenosa, ainda é motivo de investigação. As figuras 52, 53, 54 e 55 abaixo evidenciam a intrigante seletividade da eletroquimioterapia ao tecido neoplásico quando a administração do antineoplásico se dá por via intravenosa (MIR, 2006).

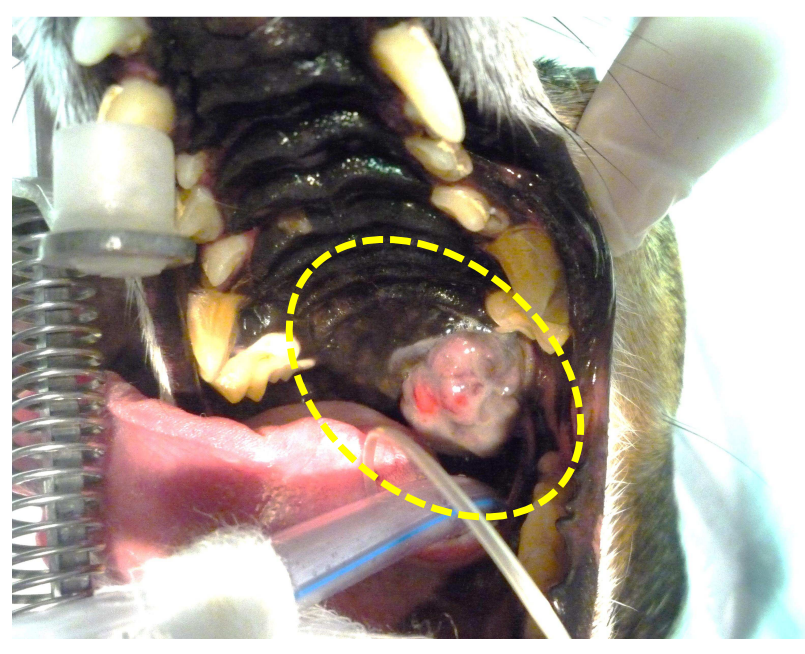

Figura 52 - Imagem mostra melanoma em cavidade oral antes da sessão de eletroquimioterapia. A linha pontilhada amarela representa o local de aplicação dos pulsos elétricos para eletroquimioterapia. A abordagem é feita tratando as margens do tumor com objetivo de tratar as possíveis infiltrações neoplásicas.

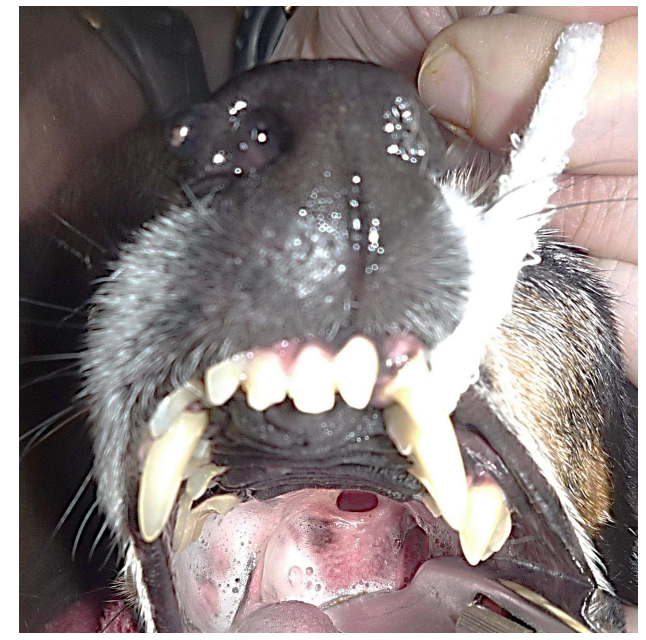

Figura 53 - Imagem de 4 semanas após o tratamento mostra que embora tenha sido feita margem de segurança com eletroquimioterapia, macroscopicamente a destrição se deu somente no local onde existia a formação. Isso evidencia a seletividade da ECT ao local da neoplasia. 


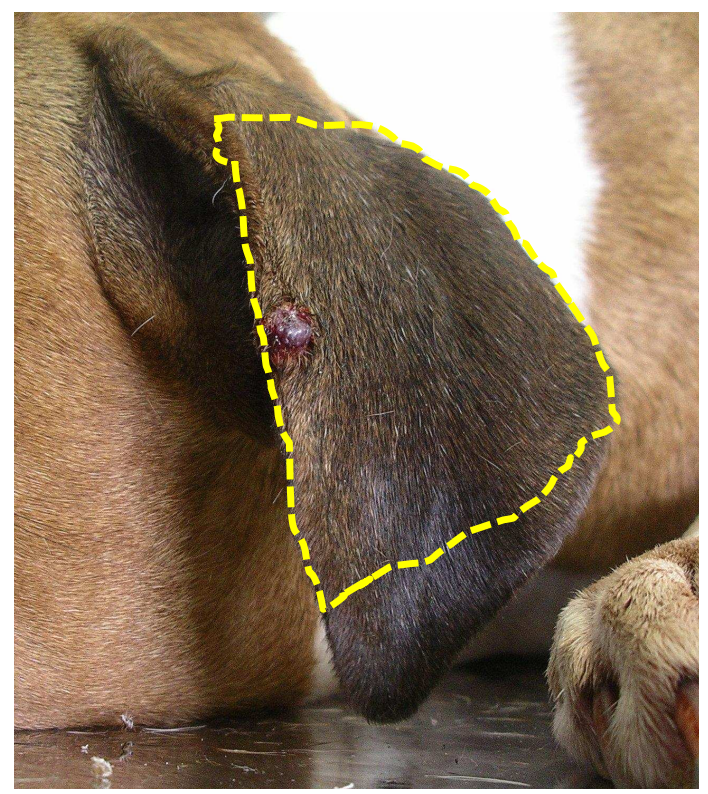

Figura 54 - Imagem mostra mastocitoma em região de orelha de cão. A linha pontilhada amarela representa o local de aplicação dos pulsos elétricos. Foi tratada quase que a orelha inteira do cão.

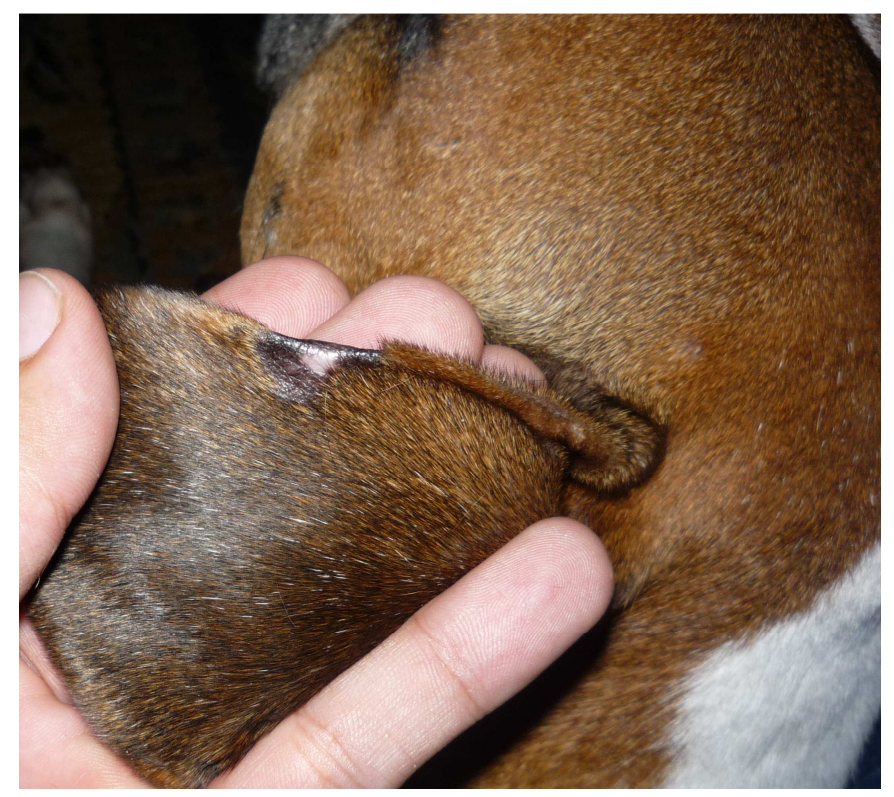

Figura 55 - Imagem mostra que somente no local da formação em regiões adjacentes bem próximas houve a formação de cicatriz, evidenciando desta forma a seletividade da eletroquimioterapia ao tecido neoplásico.

Uma das motivações deste trabalho foi no sentido de se observar os possíveis diferentes comportamentos, em relação à expressão gênica, frente ao desafio da eletroporação, das células neoplásicas e não neoplásicas e estabelecer uma possível correlação com o efeito seletivo da eletroquimioterapia observado em experimentos in vivo e clinicamente. Antes de realizarmos os experimentos in vitro, então foram realizados os experimentos com eletroquimioterapia in vivo justamente para vivenciarmos todas as alterações encontradas na literatura. Assim nossas observações e inferências não viriam somente das publicações científicas, mas também de nossa própria experiência. Isso trouxe muito mais concretude ao desenvolvimento do trabalho, além de nos proporcionar a oportunidade de desenvolvermos o "know how" com eletroquimioterapia.

Os resultados encontrados nos experimentos in vivo, foram coerentes aos encontrados por outros grupos de pesquisa. Os $82 \%$ de resposta objetiva alcançados pelo experimento são bem semelhantes aos encontrados na literatura. Os $25 \%$ de resposta completa obtidos foram menores do que aqueles encontrados em outros trabalhos, porém como em nosso experimento a via de administração do agente antineoplásico foi intratumoral essa diminuição era esperada, uma vez que 
uma distribuição homogênea por toda neoplasia é dificultada, diminuindo a eficiência da terapia. O modelo experimental por nós utilizado, o melanoma da linhagem B16/F10 é altamente infiltrativo e isso também interferiu nos resultados, pois onde não havia distribuição do agente antineoplásico não havia resposta (HELLER et al., 1997). Com o experimento pudemos observar também as características clínicas descritas em outros experimentos, como a formação de edema, ulcerações e crostas no entorno da formação, evidenciando a destruição da neoplasia (MIR, 1994; MIR et al., 1997). Outro efeito importante observado durante as sessões foram as contrações musculares descritas na literatura(MIKLAVCIC et al., 2005). Tal efeito não promoveu nenhuma alteração clínica durante o período em que os animais estiveram monitorados, que coincidiu com o fim dos experimentos. $O$ efeito seletivo ao tumor também pode ser observado conforme se pode observar nas figuras 56 e 57. Enfim nossos resultados tanto confirmaram que a realização do procedimento de eletroquimioterapia foi feito de maneira correta como corroboram a alta eficiência da técnica no tratamento de neoplasias localizadas.

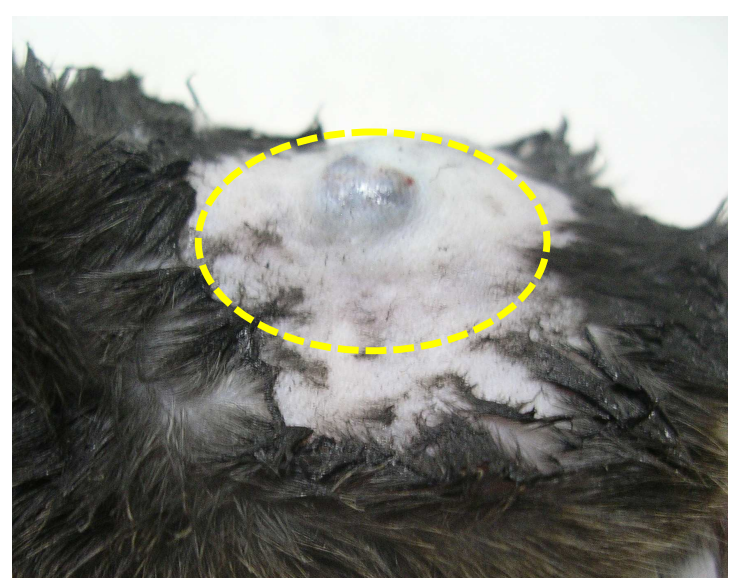

Figura 56 - Formação do melanoma da linhagem B16/BL6 implantado em camundongo C57/bl6. A linha tracejada amarela indica onde foi aplicado o campo para eletroquimioterapia

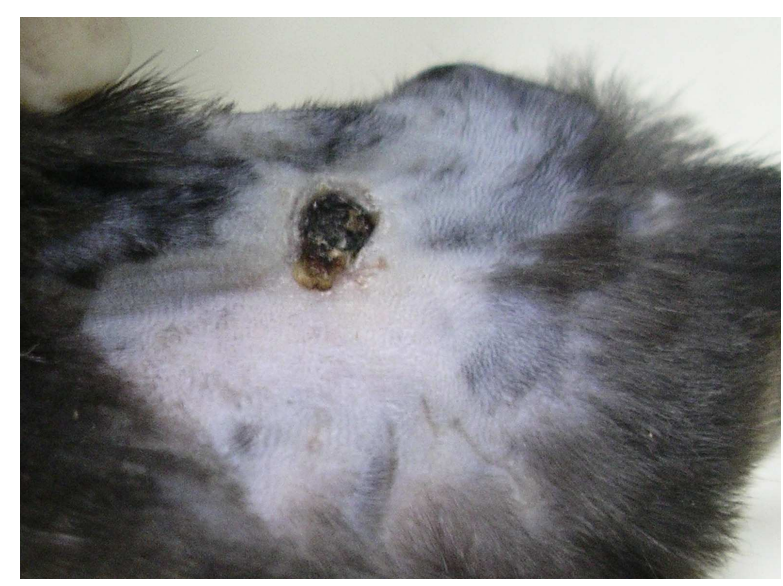

Figura 57 - Dois dias após a sessão de eletroquimioterapia podemos observar que a destruição se deu predominantemente no local da formação.

A sequência do projeto foi o desenvolvimento dos experimentos in vivo. Neles foram feitas as avaliações de interferência da eletroporação na expressão de Cx 26 para a linhagem de melanoma B16/BL6 e da Cx 43 para as linhagens de pulmão E10 (não neoplásica) e E9 neoplásica. O foco no estudo das conexinas foi em virtude da importância que essa família de genes vem ganhando na pesquisa oncológica. Os 
genes que codificam para conexinas têm sido considerados genes supressores tumorais, ou mesmo participantes do processo de disseminação de neoplasias, de acordo com a fase de progressão tumoral e podem ser chave para o desenvolvimento de novos marcadores prognostico e novas terapias (NOMURA et al., 2010) contra o câncer. As hipóteses levantadas a este respeito dizem que a expressão de conexinas podem ser marcadores prognósticos tanto para 0 desenvolvimento de câncer em indivíduos sem a doença, ou em processos iniciais (displasias e neoplasias benignas) quanto para o potencial de metástase da doença em indivíduos já acometidos pelo câncer. Com relação aos possíveis tratamentos se imaginam possibilidades de utilização de drogas ou mesmo terapia gênica para aumentar ou diminuir a expressão de Cxs em neoplasias com o objetivo de diminuir o crescimento ou mesmo o potencial metastático. A eletroporação vem ganhando espaço como um vetor não viral utilizado para realização de transfecção gênica (FAURIE et al., 2010). Tanto nas hipóteses de utilização como marcadores prognostico quanto na utilização como terapias devido ao comportamento heterogêneo de expressão de conexinas em neoplasias e suas implicações, ainda não se chegou a resultados mais concretos que indiquem de maneira segura suas aplicações. Uma aplicação mais promissora das conexinas em terapia é a associação com o efeito bystander no reestabelecimento de canais intercelulares para entrega de drogas e pró-drogas dentro das células tumorais. (KANDOUZ; BATIST, 2010; NAUS; LAIRD, 2010). Dada essa importância nos estudos de oncologia os próximos experimentos têm a importância de avaliar as possíveis interferências da eletroporação na expressão desses genes.

Primeiramente o modelo experimental utilizado foi a linhagem de melanoma B16/BL6, uma linhagem que segundo a literatura tem expressão abundante de Cx 26 com níveis maiores inclusive que ao do tecido hepático. (ITO et al., 2002). Os resultados para essa linhagem com a técnica de imunofluorescência para a Cx 26 apontam ausência de marcação em membrana e marcação intracitoplasmática. A possível localização intranuclear não pode ser excluída através desta técnica uma vez que avaliamos uma imagem em duas dimensões de uma situação que está em três dimensões. A ausência de marcação para conexinas em membrana está de acordo com trabalhos realizados que apontam justamente para ausência de formação de junções gap entre os melanócitos neoplásicos para esta mesma 
linhagem, B16/BL6 (ITO et al., 2002). Não houve diferença de marcação entre os grupos. Os resultados com a técnica de western blot mostram que a interferência da eletroporação ocorreu de maneira transiente nos grupos $t_{1 / 2}$ e $t_{1}$. A diminuição na expressão de proteínas e também nos níveis de transcrição de RNAm são coerentes com a idéia de que quanto menos RNAm a ser traduzido menos síntese de proteínas ocorreria. Embora esse pensamento seja simplório, uma vez que entre a transcrição de conexinas e a síntese das proteínas existe um longo percurso, uma vez que os principais fatores envolvidos, no caso a tradução e degradação (DE SOUSA ABREU et al., 2009) não tenham sofrido nenhuma alteração o argumento poderia ser válido. Após o grupo $t_{1}$ os demais grupos apresentaram níveis semelhantes aos apresentados pelo grupo controle. Isso além de ser coerente com a característica transiente dos eletroporos formados no experimento, pode ser um indício que os processos de síntese e degradação ou estejam íntegros ou já se restituíram. A respeito da restituição das membranas, já foi mensurado que cerca de $50 \%$ das células da linhagem B16 tem sua membrana reconstituída em cerca de 5 minutos após a exposição eletroporação reversível, e todas as células têm suas membranas reconstituídas dentro de 30 minutos (KANDUSER et al., 2006).

Os próximos experimentos foram feitos com o objetivo de se comparar os possíveis efeitos de interferência na expressão das conexinas entre uma linhagem de células não neoplásicas e outra neoplásica de mesma origem. As células epiteliais de pulmão E10 e as transformadas E9 foram submetidas às mesmas condições experimentais para que fizéssemos uma analise comparativa entre elas. A linhagem de pulmão não transformada apresentou resultados diferenciados dos apresentados pela linhagem neoplásica. A técnica de imunofluorescência para Cx 43 mostrou uma marcação bem evidente e predominante em membranas na linhagem neoplásica E9. Isso corrobora a idéia da participação das conexinas e junções gap nos processos de disseminação e metástase apresentados por alguns grupos de pesquisa (CARYSTINOS et al., 2001; ZHANG et al., 2001; ITO et al., 2002; HAASS et al., 2004; SAITO-KATSURAGI et al., 2007; HAASS et al., 2010; NAUS; LAIRD, 2010). Uma diferença observada foi a diminuição acentuada de marcação em membrana e aumento da marcação em citoplasma no tempo $t_{1 / 2}$. Nesse grupo foi observada uma diminuição de proteínas conforme descrito na sequencia. Essa alteração poderia estar evidenciando o trafego desde sua síntese em reticulo 
endoplasmático rugoso, oligomerização em conexon no complexo de Golgi e trafego através dos microtúbulos até a membrana citoplasmática das novas conexinas sintetizadas para formação da placa juncional (SEGRETAIN; FALK, 2004). $\mathrm{Na}$ linhagem E10 as marcações da imunofluorescência para $C x 43$ foram em membranas, porém com marcações também em citoplasma. As células da linhagem E10 não apresentaram diferença na imunofluorescência para conexina 43 entre os diferentes grupos. As figuras 58, 59 e 60 mostram as diferentes marcações para as conexinas nas diferentes linhagens do trabalho.

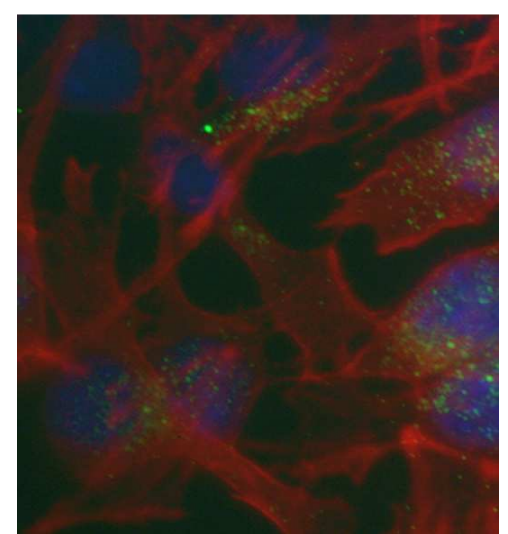

Figura 58 - Marcação da imunofluorescência para Cx 26 (em verde) na linhagem de células de melanoma B16/BL6. Marcação intracitoplasmática. (objetiva 40x)

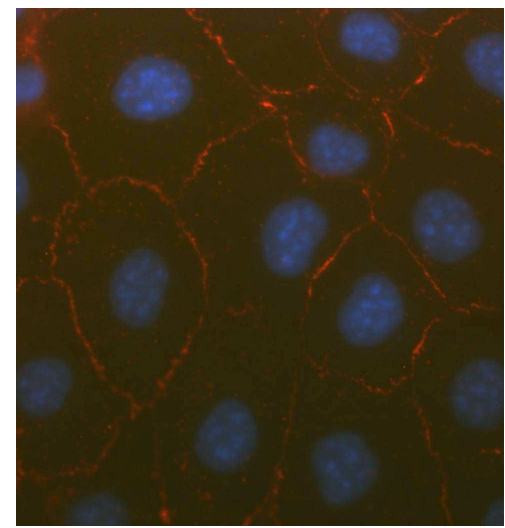

Figura 59 - Marcação da imunofluorescência para Cx 43 (em vermelho) na linhagem neoplásica de pulmão E9.. Marcação predominante em membrana. (objetiva 40x)

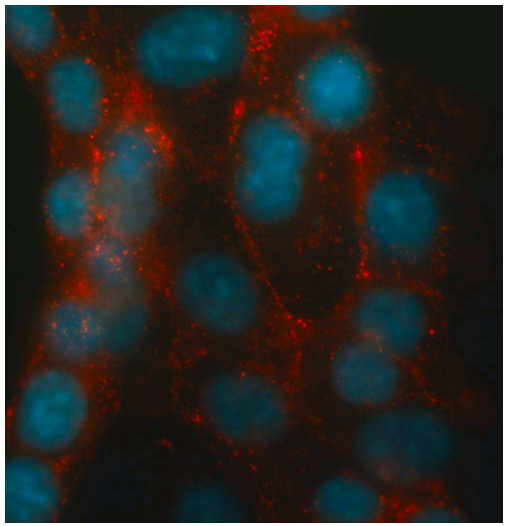

Figura 60 - Marcação da imunofluorescência para Cx 43 (em vermelho) na linhagem não neoplásica de pulmão E10. Marcação predominante em membrana, porém também há marcação evidente em citoplasma. (objetiva 40x)

Em relação à expressão de proteínas não houve diferença significativa entre os diferentes grupos, embora os grupos $t_{1 / 2}$ e $t_{1}$ tenham apresentado valores ligeiramente maiores que os demais grupos, fato este que não aconteceu na linhagem E9. A linhagem E9 apresentou comportamento semelhante ao da linhagem de melanoma B16/BL6, com diminuição somente nos grupos $t_{1 / 2}$ e $t_{1}$. Já em relação aos níveis de transcrição de RNAm a linhagem não neoplásica E10, interessantemente, apresentou níveis de transcrição mais altos justamente nos grupos $t_{1 / 2}$ e $t_{1}$, onde se encontrou níveis de proteínas ligeiramente maiores (embora sem diferença significativa entre os demais grupos) pela técnica de western blot. $O$ que poderíamos inferir é que a eletroporação de alguma forma sinalizaria para um 
aumento de transcrição de RNAm para a Cx 43 que não chega a interferir de maneira significativa nos níveis de proteínas. Essa sinalização poderia vir por meio da própria perturbação nas membranas promovida pela formação de poros. Já é sabido que a desagregação das células em experimentos em cultura de células promove a formação dos conexossomos, que são internalizados e desaparecem rapidamente, podendo aumentar as taxas de síntese e degradação das conexinas se comparadas com as células em condições fisiológicas (HERVÉ et al., 2007). A própria eletroporação promove o descolamento de algumas células que estão aderidas as placas de Petri o que também poderia desencadear um estímulo semelhante ao anterior. As placas juncionais uma vez formadas dificilmente são desfeitas sob condições fisiológicas (SEGRETAIN; FALK, 2004) e a perturbação na membrana promovida pela eletroporação seria a responsável por sua desagregação ou mesmo formação de conexossomos.

Os resultados da linhagem de células de pulmão E9 apresentaram resultados diferentes da linhagem E10 em relação ao nível de transcrição de RNAm para a Cx 43. Os níveis de transcrição apresentaram comportamento bem heterogêneo, não permitindo nenhuma inferência a respeito dos mecanismos que poderiam estar envolvidos no padrão apresentado. Como as células neoplásicas podem apresentar padrões aberrantes de expressão gênica esse pode ser o fato aplicável no caso desta técnica. Uma evidência de tal fato pode ser o alto desvio padrão apresentado pelo grupo controle com a técnica de PCR em tempo real. O desvio padrão apresentado é da mesma ordem de grandeza da medida do nível de transcrição de RNAm para a Cx 43. O fato observável que merece atenção nesse caso é que ambas as linhagens apresentaram comportamento semelhante de diminuição Cxs, em nível proteico, com uma diminuição transiente nos tempos $t_{1 / 2}$ e $t_{1}$.

Sob o ponto de vista geral, podemos afirmar que a eletroporação interferiu na expressão de conexinas. Com a expansão da utilização da eletroporação e a tendência de sua utilização em aplicações clínicas a pesquisa dos efeitos da aplicação de campos elétricos em células e organismos vivos tem aumentado e alguns trabalhos têm sido produzidos nos últimos anos e a interferência do fenômeno de eletroporação na expressão de alguns genes já foi evidenciada em alguns trabalhos (LEPIK et al., 2003; MLAKAR et al., 2009). O objetivo destes trabalhos foi avaliar a possível interferência do fenômeno de eletroporação na 
expressão genica de células de neoplasias malignas e seu possível potencial tumorigênico. Os resultados não apontaram nenhuma alteração na expressão de genes supressores de tumor ou oncogenes, porém foi evidenciada que a eletroporação seria um estímulo de extremo estresse celular. Isso foi evidenciado nestes trabalhos através do aumento da expressão de genes da família HSPA (heat shock protein) após exposição de células a campos elétricos semelhantes aos utilizados em eletroquimioterapia e na realização de transfecção gênica. Outro achado importante foi que genes envolvidos na síntese protéica estavam com baixa expressão (MLAKAR et al., 2009). Este último achado está em comum acordo com os resultados deste trabalho que também apresentaram nas linhagens neoplásicas baixa expressão de proteínas de maneira transiente. O que imaginamos é que a formação de poros na membrana prejudica de maneira significativa a homeostase celular, pois o desbalanço de íons entre os compartimentos extracelular e intracelular, a perda de ATP através dos poros, entre outros metabólitos essenciais ao equilíbrio da fisiologia celular acabem prejudicando a maquinaria de síntese de proteínas, além de ser um estimulo semelhante ao estresse térmico. Os trabalhos anteriormente citados não fizeram uma analise de células não neoplásicas, porém os nossos resultados poderiam indicar que as células não transformadas conseguiriam enfrentar o desafio da eletroporação de maneira mais eficiente. As alterações encontradas dão indícios que as perturbações desencadeadas pelo fenômeno são eficientemente contornadas pelas células normais.

Os resultados dos estudos aqui apresentados tinham como objetivo uma avaliação inicial da interferência da eletroporação na expressão dos genes das conexinas e estabelecer uma comparação entre os comportamentos de genótipos neoplásicos e não neoplásicos in vitro. Temos ciência que o que encontramos remetem a muitas outras perguntas e com certeza mais trabalhos podem ser desenvolvidos na sequencia deste para ajudar a elucidar os motivos da interferência da eletroporação na expressão genica e os efeitos desencadeados de acordo com a família de genes que apresentem alterações. 


\section{CONCLUSÕES}

Diante dos resultados obtidos pelo presente trabalho de pesquisa podemos concluir que o fenômeno de eletroporação interfere na expressão de conexinas de maneira transiente. Outro apontamento é que uma linhagem neoplásica não apresenta as mesmas alterações após a eletroporação que uma linhagem não transformada. Os mecanismos envolvidos tanto no comportamento transiente das alterações encontradas quanto nos diferentes comportamentos entre células neoplásicas e não neoplásicas, embora tenham sido sugeridos em parte na discussão, não foram objetivos deste trabalho e ainda precisam ser elucidados. 


\section{REFERÊNCIAS}

BASFORD, J. R. A historical perspective of the popular use of electric and magnetic therapy. Arch. Phys. Med. Rehabil., v. 82, n. 9, p. 1261-1269, 2001.

BEARDSLEE, M. A.; LAING, J. G.; BEYER, E. C.; SAFFITZ, J. E. Rapid turnover of connexin43 in the adult rat heart. Circ. Res., v. 83, n. 6, p. 629-635, 1998.

CARYSTINOS, G. D.; BIER, A.; BATIST, G. The role of connexin-mediated cell-cell communication in breast cancer metastasis. J. Mammary Gland. Biol. Neoplasia., v. 6, n. 4, p. 431-440, 2001.

CEMAZAR, M.; TAMZALI, Y.; SERSA, G.; TOZON, N.; MIR, L. M.; MIKLAVCIC, D.; LOWE, R.; TEISSIE, J. Electrochemotherapy in veterinary oncology. J. Vet. Intern. Med., v. 22, n. 4, p. 826-831, 2008.

CHANG, D. C.; REESE, T. S. Changes in membrane structure induced by electroporation as revealed by rapid-freezing electron microscopy. Biophys. J., V. 58, n. 1, p. 1-12, 1990.

CHERNYSH, A. M.; KOZLOVA, E. K.; MOROZ, V. V.; BORSHAGOVSKAYA, P. Y.; BLIZNUK, U. A.; RYSAEVA, R. M. Erythrocyte membrane surface after calibrated electroporation: visualization by atomic force microscopy. Bull. Exp. Biol. Med., v. 148, n. 3, p. 455-460, 2009.

CHIPMAN, J. K.; MALLY, A.; EDWARDS, G. O. Disruption of gap junctions in toxicity and carcinogenicity. Toxicol. Sci., v. 71, n. 2, p. 146-153, 2003.

COROVIC, S.; AL SAKERE, B.; HADDAD, V.; MIKLAVCIC, D.; MIR, L. M. Importance of contact surface between electrodes and treated tissue in electrochemotherapy. Technol. Cancer Res. Treat., v. 7, n. 5, p. 393-400, 2008.

CRONIER, L.; CRESPIN, S.; STRALE, P.; DEFAMIE, N.; MESNIL, M. Gap junctions and cancer: new functions for an old story. Antioxid. Redox Signal., v. 11, n. 2, p. 323-338, 2009.

CUKJATI, D.; BATIUSKAITE, D.; ANDRÉ, F.; MIKLAVCIC, D.; MIR, L. M. Real time electroporation control for accurate and safe in vivo non-viral gene therapy. Bioelectrochemistry, v. 70, n. 2, p. 501-507, 2007.

DAGLI, M. L.; HERNANDEZ-BLAZQUEZ, F. J. Roles of gap junctions and connexins in non-neoplastic pathological processes in which cell proliferation is involved. $\mathbf{J}$ Membr. Biol., v. 218, n. 1-3, p. 79-91, 2007.

DANDO, R.; CHEN, W. Cellular recovery from electroporation using synchronisation modulation as a rescue model for electrically injured cells. Burns, v. 34, n. 8, p. 1128-1136, 2008. 
DE MAIO, A.; VEGA, V. L.; CONTRERAS, J. E. Gap junctions, homeostasis, and injury. J. Cell Physiol., v. 191, n. 3, p. 269-282, 2002.

DE SOUSA ABREU, R.; PENALVA, L. O.; MARCOTTE, E. M.; VOGEL, C. Global signatures of protein and mRNA expression levels. Mol. Biosyst., v. 5, n. 12, p. 1512-1526, 2009.

DE VOCHT, F. "Dirty electricity": what, where, and should we care? J. Expo Sci. Environ. Epidemiol., v. 20, n. 5, p. 399-405, 2010.

EDWARDS, G.; JONDHALE, S.; CHEN, T.; CHIPMAN, J. A quantitative inverse relationship between connexin32 expression and cell proliferation in a rat hepatoma cell line. Toxicology, v. 253, n. 1-3, p. 46-52, 2008.

FAURIE, C.; REBERSEK, M.; GOLZIO, M.; KANDUSER, M.; ESCOFFRE, J. M.; PAVLIN, M.; TEISSIE, J.; MIKLAVCIC, D.; ROLS, M. P. Electro-mediated gene transfer and expression are controlled by the life-time of DNA/membrane complex formation. J. Gene. Med., v. 12, n. 1, p. 117-125, 2010.

FENTON, J. I.; HORD, N. G. Stage matters: choosing relevant model systems to address hypotheses in diet and cancer chemoprevention research. Carcinogenesis, v. 27, n. 5 , p. 893-902, 2006.

FLISAR, K.; PUC, M.; KOTNIK, T.; MIKLAVCIC, D. Cell membrane electropermeabilization with arbitrary pulse waveforms. IEEE Eng. Med. Biol. Mag., v. 22 , n. 1, p. 77-81, 2003.

GATENBY, R. A.; FRIEDEN, B. R. Coulomb interactions between cytoplasmic electric fields and phosphorylated messenger proteins optimize information flow in cells. PLoS One, v. 5, n. 8, p. e12084, 2010.

GEHL, J. Electroporation: theory and methods, perspectives for drug delivery, gene therapy and research. Acta Physio.I Scand., v. 177, n. 4, p. 437-447, 2003.

GEHL, J. [Investigational treatment of cancer using electrochemotherapy, electrochemoimmunotherapy and electro-gene transfer]. Ugeskr Laeger, v. 167, n. 34, p. 3156-3159, 2005.

GOTHELF, A.; MIR, L.; GEHL, J. Electrochemotherapy: results of cancer treatment using enhanced delivery of bleomycin by electroporation. Cancer Treat. Rev., v. 29, n. 5, p. 371-387, 2003.

GOWRISHANKAR, T.; WEAVER, J. Electrical behavior and pore accumulation in a multicellular model for conventional and supra-electroporation. Biochem. Biophys. Res. Commun., v. 349, n. 2, p. 643-653, 2006.

GROUP, I. S. Brain tumour risk in relation to mobile telephone use: results of the INTERPHONE international case-control study. Int. J. Epidemiol., v. 39, n. 3, p. 675694, 2010. 
HAASS, N. K.; RIPPERGER, D.; WLADYKOWSKI, E.; DAWSON, P.; GIMOTTY, P. A.; BLOME, C.; FISCHER, F.; SCHMAGE, P.; MOLL, I.; BRANDNER, J. M. Melanoma progression exhibits a significant impact on connexin expression patterns in the epidermal tumor microenvironment. Histochem. Cell. Biol., v. 133, n. 1, p. 113-124, 2010.

HAASS, N. K.; SMALLEY, K. S.; HERLYN, M. The role of altered cell-cell communication in melanoma progression. J. Mol. Histol., v. 35, n. 3, p. 309-318, 2004.

HART, I. R. The selection and characterization of an invasive variant of the B16 melanoma. Am. J. Pathol., v. 97, n. 3, p. 587-600, 1979.

HEEG, S.; DOEBELE, M.; VON WERDER, A.; OPITZ, O. G. In vitro transformation models: modeling human cancer. Cell Cycle, v. 5, n. 6, p. 630-634, 2006.

HELLER, L.; HELLER, R. Electroporation Gene Therapy Preclinical and Clinical Trials for Melanoma. Curr. Gene Ther., v., n., p., 2010.

HELLER, R.; GILBERT, R.; JAROSZESKI, M. Electrochemotherapy: an emerging drug delivery method for the treatment of cancer. Adv. Drug. Deliv. Rev., v. 26, n. 23, p. 185-197, 1997.

HERVÉ, J.; DERANGEON, M.; BAHBOUHI, B.; MESNIL, M.; SARROUILHE, D. The connexin turnover, an important modulating factor of the level of cell-to-cell junctional communication: comparison with other integral membrane proteins. J. Membr. Biol., v. 217, n. 1-3, p. 21-33, 2007.

INSKIP, P. D.; HOOVER, R. N.; DEVESA, S. S. Brain cancer incidence trends in relation to cellular telephone use in the United States. Neuro. Oncol., v. 12, n. 11, p. 1147-1151, 2010.

ISHIGURO, T.; NAKAJIMA, M.; NAITO, M.; MUTO, T.; TSURUO, T. Identification of genes differentially expressed in B16 murine melanoma sublines with different metastatic potentials. Cancer Res., v. 56, n. 4, p. 875-879, 1996.

ITO, A.; KATOH, F.; KATAOKA, T.; OKADA, M.; TSUBOTA, N.; ASADA, H.; YOSHIKAWA, K.; MAEDA, S.; KITAMURA, Y.; YAMASAKI, H.; NOJIMA, H. A role for heterologous gap junctions between melanoma and endothelial cells in metastasis. J. Clin. Invest., v. 105, n. 9, p. 1189-1197, 2000.

ITO, A.; WATABE, K.; KOMA, Y.; KITAMURA, Y. An attempt to isolate genes responsible for spontaneous and experimental metastasis in the mouse model. Histol. Histopathol., v. 17, n. 3, p. 951-959, 2002.

JARM, T.; CEMAZAR, M.; MIKLAVCIC, D.; SERSA, G. Antivascular effects of electrochemotherapy: implications in treatment of bleeding metastases. Expert. Rev. Anticancer. Ther., v. 10, n. 5, p. 729-746, 2010. 
JOHNSON, C. W.; BARTH, R. F.; ADAMS, D.; HOLMAN, B.; PRICE, J. E.; SAUTINS, I. Phenotypic diversity of murine B16 melanoma detected by anti-B16 monoclonal antibodies. Cancer Res., v. 47, n. 4, p. 1111-1117, 1987.

KANDOUZ, M.; BATIST, G. Gap junctions and connexins as therapeutic targets in cancer. Expert. Opin. Ther. Targets, v. 14, n. 7, p. 681-692, 2010.

KANDUSER, M.; SENTJURC, M.; MIKLAVCIC, D. Cell membrane fluidity related to electroporation and resealing. Eur. Biophys. J., v. 35, n. 3, p. 196-204, 2006.

KING, T.; BERTRAM, J. Connexins as targets for cancer chemoprevention and chemotherapy. Biochim. Biophys. Acta., v. 1719, n. 1-2, p. 146-160, 2005.

KING, T. J.; LAMPE, P. D. Temporal regulation of connexin phosphorylation in embryonic and adult tissues. Biochim. Biophys. Acta., v. 1719, n. 1-2, p. 24-35, 2005.

KIS, E.; SZEGESDI, I.; OCSAI, H.; GYULAI, R.; KEMÉNY, L.; OLÁH, J. [Electrochemotherapy of melanoma cutaneous metastases]. Orv. Hetil., v. 151, n. 3, p. 99-101, 2010.

KJENSETH, A.; FYKERUD, T.; RIVEDAL, E.; LEITHE, E. Regulation of gap junction intercellular communication by the ubiquitin system. Cell. Signal., v. 22, n. 9, p. 1267-1273, 2010.

KOS, B.; ZUPANIC, A.; KOTNIK, T.; SNOJ, M.; SERSA, G.; MIKLAVCIC, D. Robustness of treatment planning for electrochemotherapy of deep-seated tumors. J. Membr. Biol., v. 236, n. 1, p. 147-153, 2010.

KRAMAR, P.; MIKLAVCIC, D.; LEBAR, A. M. Determination of the lipid bilayer breakdown voltage by means of linear rising signal. Bioelectrochemistry, v. 70, $\mathrm{n}$. 1, p. 23-27, 2007.

LABANAUSKIENE, J.; GEHL, J.; DIDZIAPETRIENE, J. Evaluation of cytotoxic effect of photodynamic therapy in combination with electroporation in vitro. Bioelectrochemistry, v. 70, n. 1, p. 78-82, 2007.

LAIRD, D. W. Connexin phosphorylation as a regulatory event linked to gap junction internalization and degradation. Biochim. Biophys. Acta., v. 1711, n. 2, p. 172-182, 2005.

LAMPE, P. D.; LAU, A. F. The effects of connexin phosphorylation on gap junctional communication. Int. J. Biochem. Cell Biol., v. 36, n. 7, p. 1171-1186, 2004.

LAMPE, P. D.; LAU, A. F. Regulation of gap junctions by phosphorylation of connexins. Arch. Biochem. Biophys., v. 384, n. 2, p. 205-215, 2000.

LANDSTRÖM, F. J.; NILSSON, C. O.; CRAFOORD, S.; REIZENSTEIN, J. A.; ADAMSSON, G. B.; LÖFGREN, L. A. Electroporation therapy of skin cancer in the head and neck area. Dermatol. Surg., v. 36, n. 8, p. 1245-1250, 2010. 
LARKIN, J.; COLLINS, C.; AARONS, S.; TANGNEY, M.; WHELAN, M.; O'REILY, S.; BREATHNACH, O.; SODEN, D.; O'SULLIVAN, G. Electrochemotherapy: aspects of preclinical development and early clinical experience. Ann. Surg., v. 245, n. 3, p. 469-479, 2007.

LEBAR, A. M.; SERSA, G.; KRANJC, S.; GROSELJ, A.; MIKLAVCIC, D. Optimisation of pulse parameters in vitro for in vivo electrochemotherapy. Anticancer Res., v. 22, n. 3, p. 1731-1736, 2002.

LEITHE, E.; RIVEDAL, E. Ubiquitination of gap junction proteins. J. Membr. Biol., v. 217, n. 1-3, p. 43-51, 2007.

LEPIK, D.; JAKS, V.; KADAJA, L.; VÄRV, S.; MAIMETS, T. Electroporation and carrier DNA cause p53 activation, cell cycle arrest, and apoptosis. Anal. Biochem., v. 318, n. 1, p. 52-59, 2003.

LERCHL, A. Comments on "Radiofrequency electromagnetic fields (UMTS, 1,950 $\mathrm{MHz}$ ) induce genotoxic effects in vitro in human fibroblasts but not in lymphocytes" by Schwarz et al. (Int Arch Occup Environ Health 2008: doi: 10.1007/s00420-008-03055). Int. Arch. Occup. Environ. Health., v. 82, n. 2, p. 275-278, 2009.

LI, G.; HERLYN, M. Dynamics of intercellular communication during melanoma development. Mol. Med. Today., v. 6, n. 4, p. 163-169, 2000.

LOEWENSTEIN, W. R. Permeability of membrane junctions. Ann. N. Y. Acad. Sci., v. 137, n. 2, p. 441-472, 1966.

LOEWENSTEIN, W. R.; KANNO, Y. Intercellular communication and the control of tissue growth: lack of communication between cancer cells. Nature, v. 209, n. 5029, p. 1248-1249, 1966.

MALKINSON, A. M.; DWYER-NIELD, L. D.; RICE, P. L.; DINSDALE, D. Mouse lung epithelial cell lines--tools for the study of differentiation and the neoplastic phenotype. Toxicology, v. 123, n. 1-2, p. 53-100, 1997.

MCLACHLAN, E.; SHAO, Q.; LAIRD, D. W. Connexins and gap junctions in mammary gland development and breast cancer progression. J. Membr. Biol., v. 218, n. 1-3, p. 107-121, 2007.

MESNIL, M. Connexins and cancer. Biol. Cell, v. 94, n. 7-8, p. 493-500, 2002.

MESNIL, M.; CRESPIN, S.; AVANZO, J. L.; ZAIDAN-DAGLI, M. L. Defective gap junctional intercellular communication in the carcinogenic process. Biochim. Biophys. Acta., v. 1719, n. 1-2, p. 125-145, 2005.

MIKLAVCIC, D.; MIR, L. M.; THOMAS VERNIER, P. Electroporation-based technologies and treatments. J. Membr. Biol., v. 236, n. 1, p. 1-2, 2010. 
MIKLAVCIC, D.; SNOJ, M.; ZUPANIC, A.; KOS, B.; CEMAZAR, M.; KROPIVNIK, M.; BRACKO, M.; PECNIK, T.; GADZIJEV, E.; SERSA, G. Towards treatment planning and treatment of deep-seated solid tumors by electrochemotherapy. Biomed. Eng. Online., v. 9, n., p. 10, 2010.

MIKLAVCIC, D.; PUCIHAR, G.; PAVLOVEC, M.; RIBARIC, S.; MALI, M.; MACEKLEBAR, A.; PETKOVSEK, M.; NASTRAN, J.; KRANJC, S.; CEMAZAR, M.; SERSA, $G$. The effect of high frequency electric pulses on muscle contractions and antitumor efficiency in vivo for a potential use in clinical electrochemotherapy. Bioelectrochemistry, v. 65, n. 2, p. 121-128, 2005.

MIKLAVCIC, D.; SEMROV, D.; MEKID, H.; MIR, L. M. A validated model of in vivo electric field distribution in tissues for electrochemotherapy and for DNA electrotransfer for gene therapy. Biochim. Biophys. Acta., v. 1523, n. 1, p. 73-83, 2000.

MIR, L.; GLASS, L.; SERSA, G.; TEISSIÉ, J.; DOMENGE, C.; MIKLAVCIC, D.; JAROSZESKI, M.; ORLOWSKI, S.; REINTGEN, D.; RUDOLF, Z.; BELEHRADEK, M.; GILBERT, R.; ROLS, M.; BELEHRADEK, J. J.; BACHAUD, J.; DECONTI, R.; STABUC, B.; CEMAZAR, M.; CONINX, P.; HELLER, R. Effective treatment of cutaneous and subcutaneous malignant tumours by electrochemotherapy. Br. J. Cancer, v. 77, n. 12, p. 2336-2342, 1998.

MIR, L. M. Nucleic acids electrotransfer-based gene therapy (electrogenetherapy): past, current, and future. Mol. Biotechnol., v. 43, n. 2, p. 167-176, 2009.

MIR, L. M. Therapeutic perspectives of in vivo cell electropermeabilization. Bioelectrochemistry, v. 53, n. 1, p. 1-10, 2001.

MIR, L. M.; MORSLI, N.; GARBAY, J. R.; BILLARD, V.; ROBERT, C.; MARTY, M. Electrochemotherapy: a new treatment of solid tumors. J. Exp. Clin. Cancer Res., v. 22, n. 4 Suppl, p. 145-148, 2003.

MIR, L. M.; ORLOWSKI, S. Mechanisms of electrochemotherapy. Adv. Drug. Deliv. Rev., v. 35, n. 1, p. 107-118, 1999.

MIR, L. M.; DEVAUCHELLE, P.; QUINTIN-COLONNA, F.; DELISLE, F.; DOLIGER, S.; FRADELIZI, D.; BELEHRADEK, J.; ORLOWSKI, S. First clinical trial of cat softtissue sarcomas treatment by electrochemotherapy. Br. J. Cancer., v. 76, n. 12, p. 1617-1622, 1997.

MIR, L. M. [Antitumoral electrochemotherapy]. Pathol. Biol. (Paris), v. 42, n. 6, p. 557-560, 1994.

MLAKAR, V.; TODOROVIC, V.; CEMAZAR, M.; GLAVAC, D.; SERSA, G. Electric pulses used in electrochemotherapy and electrogene therapy do not significantly change the expression profile of genes involved in the development of cancer in malignant melanoma cells. BMC Cancer, v. 9, n., p. 299, 2009. 
MUSIL, L. S.; LE, A. C.; VANSLYKE, J. K.; ROBERTS, L. M. Regulation of connexin degradation as a mechanism to increase gap junction assembly and function. J. Biol. Chem., v. 275, n. 33, p. 25207-25215, 2000.

NAKAYAMA, J.; URABE, K.; TSUCHIDA, T.; URABE, A.; TERAO, H.; TANIGUCHI, S.; HORI, Y. Differential cell- and immuno-biological properties of murine B16-F1 and F10 melanomas: oncogene c-fos expression, sensitivity to LAK cells and/or IL-2, and components of gangliosides. J. Dermatol., v. 22, n. 8, p. 549-559, 1995.

NAUS, C.; LAIRD, D. Implications and challenges of connexin connections to cancer. Nat. Rev. Cancer., v. 10, n. 6, p. 435-441, 2010.

NEUMANN, E.; KAKORIN, S.; TOENSING, K. Fundamentals of electroporative delivery of drugs and genes. Bioelectrochem. Bioenerg., v. 48, n. 1, p. 3-16, 1999.

NEUMANN, E.; ROSENHECK, K. Permeability changes induced by electric impulses in vesicular membranes. J. Membr. Biol., v. 10, n. 3, p. 279-290, 1972.

NEUMANN, E.; SCHAEFER-RIDDER, M.; WANG, Y.; HOFSCHNEIDER, P. H. Gene transfer into mouse lyoma cells by electroporation in high electric fields. EMBO. J., v. 1, n. 7, p. 841-845, 1982.

NILSSON, E.; VON EULER, H.; BERENDSON, J.; THÖRNE, A.; WERSÄLL, P.; NÄSLUND, I.; LAGERSTEDT, A. S.; NARFSTRÖM, K.; OLSSON, J. M. Electrochemical treatment of tumours. Bioelectrochemistry, v. 51, n. 1, p. 1-11, 2000.

NOMURA, S.; MAEDA, K.; NODA, E.; INOUE, T.; FUKUNAGA, S.; NAGAHARA, H.; HIRAKAWA, K. Clinical significance of the expression of connexin26 in colorectal cancer. J. Exp. Clin. Cancer Res., v. 29, n. 1, p. 79, 2010.

PAVLIN, M.; LEBEN, V.; MIKLAVCIC, D. Electroporation in dense cell suspension-theoretical and experimental analysis of ion diffusion and cell permeabilization. Biochim. Biophys. Acta, v. 1770, n. 1, p. 12-23, 2007.

PAVSELJ, N.; PRÉAT, V.; MIKLAVCIC, D. A numerical model of skin electropermeabilization based on in vivo experiments. Ann. Biomed. Eng., v. 35, n. 12, p. 2138-2144, 2007.

PEYCHEVA, E.; DASKALOV, I.; TSONEVA, I. Electrochemotherapy of Mycosis fungoides by interferon-alpha. Bioelectrochemistry, v. 70, n. 2, p. 283-286, 2007.

PLIQUETT, U.; JOSHI, R. P.; SRIDHARA, V.; SCHOENBACH, K. H. High electrical field effects on cell membranes. Bioelectrochemistry, v. 70, n. 2, p. 275-282, 2007.

PUC, M.; COROVIĆ, S.; FLISAR, K.; PETKOVSEK, M.; NASTRAN, J.; MIKLAVCIC, $D$. Techniques of signal generation required for electropermeabilization. Survey of electropermeabilization devices. Bioelectrochemistry, v. 64, n. 2, p. 113-124, 2004. 
RAPTIS, L.; FIRTH, K. L. Electroporation of adherent cells in situ. DNA Cell Biol., v. 9, n. 8, p. 615-621, 1990.

SÁEZ, J. C.; MARTíNEZ, A. D.; BRAÑES, M. C.; GONZÁLEZ, H. E. Regulation of gap junctions by protein phosphorylation. Braz. J. Med. Biol. Res., v. 31, n. 5, p. 593-600, 1998.

SAFFITZ, J. E.; LAING, J. G.; YAMADA, K. A. Connexin expression and turnover : implications for cardiac excitability. Circ. Res., v. 86, n. 7, p. 723-728, 2000.

SAITO-KATSURAGI, M.; ASADA, H.; NIIZEKI, H.; KATOH, F.; MASUZAWA, M.; TSUTSUMI, M.; KUNIYASU, H.; ITO, A.; NOJIMA, H.; MIYAGAWA, S. Role for connexin 26 in metastasis of human malignant melanoma: communication between melanoma and endothelial cells via connexin 26. Cancer, v. 110, n. 5, p. 1162-1172, 2007.

SATKAUSKAS, S.; ANDRÉ, F.; BUREAU, M. F.; SCHERMAN, D.; MIKLAVCIC, D.; MIR, L. M. Electrophoretic component of electric pulses determines the efficacy of in vivo DNA electrotransfer. Hum. Gene. Ther., v. 16, n. 10, p. 1194-1201, 2005.

SEGRETAIN, D.; FALK, M. M. Regulation of connexin biosynthesis, assembly, gap junction formation, and removal. Biochim. Biophys. Acta, v. 1662, n. 1-2, p. 3-21, 2004.

SEL, D.; LEBAR, A. M.; MIKLAVCIC, D. Feasibility of employing model-based optimization of pulse amplitude and electrode distance for effective tumor electropermeabilization. IEEE Trans. Biomed. Eng., v. 54, n. 5, p. 773-781, 2007.

SERSA, G.; JARM, T.; KOTNIK, T.; COER, A.; PODKRAJSEK, M.; SENTJURC, M.; MIKLAVCIC, D.; KADIVEC, M.; KRANJC, S.; SECEROV, A.; CEMAZAR, M. Vascular disrupting action of electroporation and electrochemotherapy with bleomycin in murine sarcoma. Br. J. Cancer., v. 98, n. 2, p. 388-398, 2008a.

SERSA, G.; MIKLAVCIC, D. Electrochemotherapy of tumours. J. Vis. Exp., v., n. 22, p., 2008.

SERSA, G.; MIKLAVCIC, D.; CEMAZAR, M.; RUDOLF, Z.; PUCIHAR, G.; SNOJ, M. Electrochemotherapy in treatment of tumours. Eur. J. Surg. Oncol., v. 34, n. 2, p. 232-240, 2008b.

SPRAY, D. C. Gap junction proteins: where they live and how they die. Circ. Res., v. 83, n. 6, p. 679-681, 1998.

SPUGNINI, E.; ARANCIA, G.; PORRELLO, A.; COLONE, M.; FORMISANO, G.; STRINGARO, A.; CITRO, G.; MOLINARI, A. Ultrastructural modifications of cell membranes induced by "electroporation" on melanoma xenografts. Microsc. Res. Tech, v. 70, n. 12, p. 1041-1050, 2007.

SUN, Y.; DWYER-NIELD, L. D.; MALKINSON, A. M.; ZHANG, Y. L.; THOMPSON, J. A. Responses of tumorigenic and non-tumorigenic mouse lung epithelial cell lines to 
electrophilic metabolites of the tumor promoter butylated hydroxytoluene. Chem. Biol. Interact., v. 145, n. 1, p. 41-51, 2003.

TESTORI, A.; TOSTI, G.; MARTINOLI, C.; SPADOLA, G.; CATALDO, F.; VERRECCHIA, F.; BALDINI, F.; MOSCONI, M.; SOTELDO, J.; TEDESCHI, I.; PASSONI, C.; PARI, C.; DI PIETRO, A.; FERRUCCI, P. F. Electrochemotherapy for cutaneous and subcutaneous tumor lesions: a novel therapeutic approach. Dermatol. Ther., v. 23, n. 6, p. 651-661, 2010.

TORRES, L. N.; MATERA, J. M.; VASCONCELLOS, C. H.; AVANZO, J. L.; HERNANDEZ-BLAZQUEZ, F. J.; DAGLI, M. L. Expression of connexins 26 and 43 in canine hyperplastic and neoplastic mammary glands. Vet. Pathol., v. 42, n. 5, p. 633-641, 2005.

TSONG, T. Y. Electroporation of cell membranes. Biophys. J., v. 60, n. 2, p. 297306, 1991.

USAJ, M.; TORKAR, D.; KANDUSER, M.; MIKLAVCIC, D. Cell counting tool parameters optimization approach for electroporation efficiency determination of attached cells in phase contrast images. J. Microsc., v., n., p., 2010.

VALIC, B.; GOLZIO, M.; PAVLIN, M.; SCHATZ, A.; FAURIE, C.; GABRIEL, B.; TEISSIÉ, J.; ROLS, M. P.; MIKLAVCIC, D. Effect of electric field induced transmembrane potential on spheroidal cells: theory and experiment. Eur. Biophys. J., v. 32, n. 6, p. 519-528, 2003.

VANSLYKE, J. K.; MUSIL, L. S. Degradation of connexins from the plasma membrane is regulated by inhibitors of protein synthesis. Cell Commun. Adhes., v. 10, n. 4-6, p. 329-333, 2003.

VINKEN, M.; VANHAECKE, T.; PAPELEU, P.; SNYKERS, S.; HENKENS, T.; ROGIERS, V. Connexins and their channels in cell growth and cell death. Cell Signal., v. 18, n. 5, p. 592-600, 2006.

WARN-CRAMER, B. J.; LAU, A. F. Regulation of gap junctions by tyrosine protein kinases. Biochim. Biophys. Acta., v. 1662, n. 1-2, p. 81-95, 2004.

WEAVER, J. C. Electroporation theory. Concepts and mechanisms. Methods. Mol. Biol., v. 55, n., p. 3-28, 1995a.

YAMASAKI, $\mathrm{H}$. Aberrant expression and function of gap junctions during carcinogenesis. Environ. Health. Perspect., v. 93, n., p. 191-197, 1991.

YANO, T.; HERNANDEZ-BLAZQUEZ, F. J.; OMORI, Y.; YAMASAKI, H. Reduction of malignant phenotype of HEPG2 cell is associated with the expression of connexin 26 but not connexin 32. Carcinogenesis, v. 22, n. 10, p. 1593-1600, 2001.

ZHANG, Y. W.; KANEDA, M.; MORITA, I. The gap junction-independent tumorsuppressing effect of connexin 43. J. Biol. Chem., v. 278, n. 45, p. 44852-44856, 2003. 
ZHANG, J.; ZHANG, H.; BU, H.; YANG, G.; LI, S.; GUO, L. [Studies of intercellular communication in human rhabdomyosarcoma cell lines of different metastatic potential]. Zhonghua Bing Li Xue Za Zhi, v. 30, n. 6, p. 448-451, 2001.

ZHAO, Z.; DENG, H. [Roles of gap junctions in tumorigenesis]. Zhonghua Bing Li Xue Za Zhi, v. 36, n. 3, p. 203-205, 2007.

ZHENG, Q. A.; CHANG, D. C. High-efficiency gene transfection by in situ electroporation of cultured cells. Biochim. Biophys. Acta, v. 1088, n. 1, p. 104-110, 1991. 